\author{
UNIVERSIDADE DE SÃO PAULO \\ Faculdade de Filosofia, Letras e Ciências Humanas \\ Departamento de Letras Clássicas e Vernáculas \\ Programa de Pós-Graduação em Literatura Portuguesa
}

\author{
Vivian Steinberg
}

\begin{abstract}
A "fala perfeita" de Fiama Hasse Pais Brandão
Um diálogo íntimo com a realidade
\end{abstract}

São Paulo

2011

(versão corrigida) 


\author{
UNIVERSIDADE DE SÃO PAULO \\ Faculdade de Filosofia, Letras e Ciências Humanas \\ Departamento de Letras Clássicas e Vernáculas \\ Programa de Pós-Graduação em Literatura Portuguesa
}

\title{
A "fala perfeita" de Fiama Hasse Pais Brandão \\ Um diálogo íntimo com a realidade
}

\author{
Vivian Steinberg
}

Tese de doutorado apresentada ao Programa de Pós-Graduação em Literatura Portuguesa, do Departamento de Letras Clássicas e Vernáculas da Faculdade de Filosofia, Letras e Ciências Humanas da Universidade de São Paulo, para obtenção do título de Doutor em Letras.

Orientadora: Profa. Dra. Maria Helena Nery Garcez

De acordo:

São Paulo

2011

Versão Corrigida 
À Cris, ao Cauê e ao Lucas

uma síntese possível 


\section{AGRADECIMENTOS}

Agradeço

À Prof ${ }^{a}$. Dra. Maria Helena Nery Garcez, que me orientou com companheirismo, dedicação, confiança e competência nos caminhos da reflexão poética.

À Prof ${ }^{\mathrm{a}}$. Dr ${ }^{\mathrm{a}}$. Maria Teresa Dias Furtado, que me orientou durante o estudo em Lisboa.

Ao Prof. Dr. Horácio Costa, que me apresentou a poesia de Fiama Hasse Pais Brandão e que levantou questões e sugestões competentes no exame de qualificação.

À Prof ${ }^{a}$ Dra. Paola Poma pela competência e sugestões dadas no exame de qualificação.

Ao Gastão Cruz pelo incentivo, carinho, generosidade e presteza em me fornecer documentos e esclarecimentos.

Ao Prof. Dr. Jorge Fernandes da Silveira pelo carinho, confiança e esclarecimentos específicos.

À CAPES pela concessão de bolsa científica durante dois anos.

Ao Santander pela concessão de bolsa científica que favoreceu as pesquisas em Portugal.

À Casa Fernando Pessoa em Lisboa pela acolhida calorosa, por enviar documentos e publicações importantes e pela organização do "Colóquio Fiama Hasse Pais Brandão", em especial à Inês Pedrosa e à Ana Paula Carvalheira.

Ao Prof. Dr. Pedro Eiras e à $\operatorname{Prof}^{\mathrm{a}} \operatorname{Dr}^{\mathrm{a}}$. Joana Matos Frias por me enviarem ensaios críticos fundamentais.

À Beatriz Saiani e à Thais Mariano pela tradução do resumo.

Aos meus colegas professores pelo incentivo e à Vera e à Zezé, em especial.

À Deborah, Mirian, Isabel, Emerson, Luís e Sílvio pelos caminhos cruzados.

À Manoa, Clara, Yasmin, Jonas, Leonardo, Iuri, Gabriel, Henrique, Luana, Sophia, Thomas, Clara e Álvaro pela alegria de ser.

Ao meu grande amigo Sérgio Montero pela leitura atenta e pelas conversas poéticas e filosóficas.

Ao Cauê pelas leituras da tese enquanto ainda sem forma.

À Cris pelo amor e incentivo sempre.

Ao Lucas pelo companheirismo nas horas especiais 


\section{Resumo}

Este trabalho tem como objeto de estudo a investigação da poética de Fiama Hasse Pais Brandão buscando entender o que é "fala perfeita" para a Autora. Analisamos minuciosamente o poema "Teoria da Realidade - tratando-a por tu", que é toda uma poética, e o relacionamos com sua obra, demonstrando assim uma coerência em seu projeto poético. O poema analisado faz parte da série "Poéticas", do livro Cenas Vivas de 2000.

Nesse poema há um desdobramento do sujeito poético que persegue sua voz desde seus balbucios. Podemos dizer que o sujeito da enunciação nos conta como sua voz poética apareceu, desenvolveu, adquiriu a "fala perfeita" e a ofereceu aos leitores.

Desde a publicação de Morfismos, em 1961, que a Autora preocupou-se em resgatar a língua da estreiteza de seu uso comum e em dar autonomia à linguagem, buscando o que chamou de poesia/ substantivo, assim se filiando à tradição da modernidade e especificamente a Mallarmé. Seus poemas são testemunhos de tudo o que foi escrito e lido por ela, desde as grandes epopeias e a Bíblia, à tradição anglogermânica, aos grandes poetas americanos e à tradição portuguesa.

Fizemos um percurso em sua obra perseguindo poemas que são poéticas, ou seja, que o tema é a própria poesia para descobrir como se dá a visão e o conhecimento que Fiama tem do real e do poético. Constatamos que fez uma opção pela realidade. A matéria poética de Fiama pertence à terra, há uma preocupação em desvendar o real.

Podemos constatar essas questões, a partir da nossa leitura dos poemas de Obra Breve - Poesia Reunida. Selecionamos um percurso poético que desaguou em "Teoria da Realidade - tratando-a por tu", o que nos mostrou a intimidade que adquiriu com a realidade, além de nos revelar como sua voz poética desabrochou. 


\section{Palavras - chaves:}

Fiama Hasse Pais Brandão, Poesia 61, "Teoria da Realidade - tratando-a por tu”, poesia moderna portuguesa, poesia do fim do século XX, realidade, intimidade, poesia/ substantivo, "fala perfeita". 


\begin{abstract}
This study has its object of research the poetry of Fiama Hasse Pais Brandão, attempting the understanding of what the "perfect speech" means to the author herself. Detailed examination of the poem "Teoria da Realidade - tratando-a por tu" (The Theory or Reality - getting familiar with it), reflects the complete author's poetic, embracing Fiama's work as a whole. The poem analyzed makes part of the series "Poetics" (Poetics) from the Cenas Vivas (Living Scenes) book dated from the year 2000.
\end{abstract}

There is in this poem the unfolded poetic subject that chases her muttering voice. We can say the enunciation subject tells us how the poetic voice had emerged, developed, acquiring the "perfect speech" thus offering it at last to its readers.

Since the publication of Morfismos (Morphisms) in 1961, the Author worries about the language narrowness, rescuing from its ordinary use. Giving autonomy to it as well as searching what she had called the poetry/noun. This way Fiama's poetry filiation relies on the modern tradition and specifically in Mallarmé. Her poems witness all the things that has been written and read by her. From great epics to the Bible, the Anglo-Germanic tradition to the great American poets also including in this list the Portuguese tradition as well.

The path throughout her work has chased poems that are poetic, in other words, that the theme is the poetry itself, revealing the envisioning and the knowledge Fiama has from reality as well as poetry. It has been detected she opted for reality. The poetic material for her, belongs to the Earth where there is a concern to unveil what is real.

These matters have been attested based on the reading of the poems of the Obra Breve - Poesia Reunida (Brief Works). The poetic path selected ended up in the "Teoria da Realidade - tratando-a por tu" (Theory of Reality- getting familiar with it), this has exposed us the intimacy that she has gained with reality, revealing at same the time how her poetic voice blossomed. 


\section{Key words}

Fiama Hasse Paes Brandão, Poesia 61 (Poetry 61), Teoria de Realidade - tratando-a por tu (Theory of Reality - getting familiar with it), modern Portuguese poetry, poetry from the end $20^{\text {th }}$ century, reality, intimacy, poetry/ noun, "perfect speech". 


\section{Sumário}

Introdução

\section{Capítulo 1}

1. Contexto histórico-literário da obra de Fiama Hasse Pais Brandão .................................15

2.Crítica das obras poéticas da Autora..............................................................................25

\section{Capítulo 2}

A "Fala perfeita" de Fiama Hasse Pais Brandão - um itinerário da poesia da Autora.

\section{Capítulo 3}

"Teoria da realidade - tratando-a por tu - uma arte poética

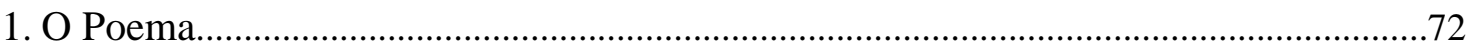

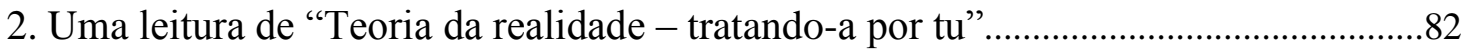

Conclusão

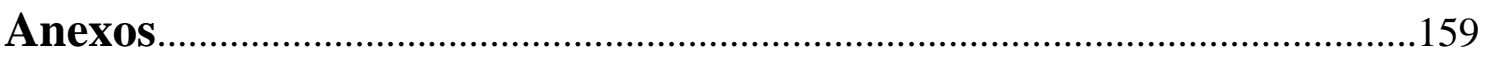

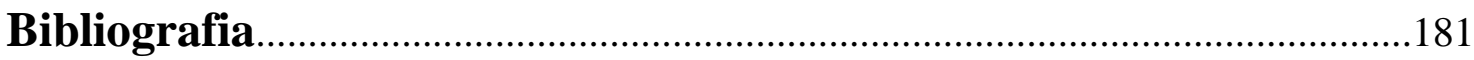




\section{Introdução}

"Tu, realidade, és nome de ti

e do que os poetas fundam,

depois de terem a fala perfeita."

Fiama Hasse Pais Brandão 
A "fala perfeita" é uma expressão retirada do poema "Teoria da Realidade: tratando-a por tu", que foi publicado em Cenas Vivas (2000). Faremos uma análise minuciosa dele para compreendermos como se dá a "fala perfeita" da voz da enunciação de Fiama Hasse Pais Brandão e qual é sua relação com a realidade. Temos a consciência que esse poema produz múltiplos diálogos com sua obra e com a de outros poetas. Mostra-nos a coerência do percurso poético desenvolvido pela Autora como um todo, desde a publicação de Morfismos, em 1961.

Fiama, em sua trajetória poética, principia pela palavra condensada, pela palavra substantivo. Amplia o sentido convencional da palavra, na esteira de Mallarmé. Acentua essa passagem de autor em autor. Como ela pronunciou em 1961: “A forma poética é a destruição do hábito linguístico". Em sua poética, percebemos, e ela mesma se pronuncia em relação às vivências de sua vida, que há a experiência da "leituraconvívio", ou seja, além das vivências da sua vida, há a experiência da leitura profunda, a que ela denomina "leitura-convívio".

Aquiesceu perante ela mesma que vivia como Eu lírico e o enreda em outros autores poetas, transformando seus poemas numa via de mão dupla: dos poetas para ela e dela para os poetas. "Lápide e versão indistintamente". "O anterior ou é uma lápide (tudo está aí, fixo) ou, então, uma versão, uma interpretação, em mim, para sempre. Assim, confesso: eu escrevo como os poetas, e com os Poetas", escreve a autora em "A minha poesia e referências literárias". O que não a impede de clamar: "Flosa, mãe, mar, em que versos/ somente sois as palavras minhas?” (BRANDÃO, 2006, p.697).

Percorre um caminho singular, relaciona a realidade empírica com a realidade do poema, não perde esse referencial: o poema é realidade também. Dito de outra forma: "Esse modo hipotético de estar entre a realidade do mundo e a realidade do poema" (SILVEIRA, 2006, p.56). Ou ainda: "Fiama: está entre a palavra e as coisas", como escreveu Eduardo Lourenço no prefácio à sua Obra Breve.

A partir dessa reflexão, podemos dizer que os textos se dobram sobre si mesmos, fazendo do exercício da escrita o objeto de reflexão, nas palavras de Jorge Fernandes da Silveira. 
Salientamos aspectos relevantes da sua poética: o intercâmbio entre a realidade do mundo e a realidade do poema e o desdobrar dos versos dela e de outros poetas presentes em sua obra, o que leva a uma poesia reflexiva, que pensa sobre si mesma e que reflete versos dela e de outrem.

Neste trabalho defenderemos a ideia de que Fiama constrói, ao longo dos poemas, a "fala perfeita", que se mescla à de autores lidos, em tempos e lugares dispersos. Desperta sua voz poética, primeiro pela leitura de Sophia de Melo Breyner Andresen, depois pela de autores modernos e contemporâneos portugueses e estrangeiros, pelas vozes clássicas, e seus versos vão adquirindo coloridos próprios. Nunca se separa da realidade, ao contrário, adquire intimidade.

No primeiro capítulo, abordaremos o contexto histórico-literário de sua obra e a fortuna crítica sobre sua poética. Começaremos pela última homenagem presenciada pela autora deste trabalho, o Colóquio Fiama Hasse Pais Brandão 29 e 30 de outubro de 2010, que aconteceu na Casa Fernando Pessoa, em Lisboa, com organização de Gastão Cruz, e resultou no número dois da revista Pessoa, publicação da Casa Fernando Pessoa. Por fim, incluiremos uma entrevista, que Fiama concedeu juntamente com os outros poetas que escreveram o livro Poesia 61, ao Diário de Lisboa em 25 de maio de $1961^{1}$.

No segundo capítulo, faremos um itinerário da poesia de Fiama Hasse Pais Brandão. Começaremos pelo poema "Grafia 1", uma arte poética. Percorreremos um caminho sugerido primeiramente pela poeta, através de seus poemas, e desaguaremos na opção que ela faz pela terra, pela realidade presente e cotidiana, não nos esquecendo que os poemas fazem parte da realidade. Com isso, Fiama nos conscientiza da materialidade da palavra e amplia o sentido de cada uma no poema. Ao penetrarmos no universo poético de Fiama, nos deparamos com o modo como ela trata a realidade, trabalha com a realidade do mundo como matéria viva.

E, por fim, trataremos do poema "Teoria da Realidade - tratando-a por tu", poema no qual ela expõe o nascimento e amadurecimento de sua voz poética, no qual nos conta o seu percurso poético e nos relata a proximidade que adquire com a realidade.

\footnotetext{
${ }^{1}$ Essa entrevista encontra-se em "Anexos" desta tese.
} 
É um poema em que se desenrola "uma espécie de fenomenologia do falar antes da fala" (LOURENÇO, 2011, p.8). O sujeito poético desenvolve as entranhas do fazer poético, na verdade, da criação e desenvolvimento da voz poética, da "fala perfeita", "a fala surge como segunda criação do já criado" (LOURENÇO, 2011, p.8). São dobras da criação onde são mostradas as entranhas da criação da voz poética, da realidade poética e do real como matéria poética.

Em nossas considerações finais, constatamos a proximidade e intimidade que Fiama Hasse Pais Brandão adquire com a realidade, não como Alberto Caeiro, que precisa da natureza para se convencer da existência, ou como os românticos, que vêem na natureza a projeção de sua existência. Na poética de Fiama, a realidade adquire sentido no espaço que a poesia lhe assinala. As palavras e a realidade presentes no poema de Fiama incham de sentido, invadem espaços e tempos. A última imagem de "Teoria da Realidade: tratando-a por tu" é que a poeta se oferece nuamente ao beijo da realidade mais inacessível, por próxima, nas palavras de Eduardo Lourenço. 


\section{Capítulo 1}

Contexto histórico-literário da obra poética de Fiama Hasse Pais Brandão e a crítica da poesia da Autora

Este tecido encadeia-me. Eu estou atenta

ao tecido da minha vida. (...)

O contexto que de novo amanhece

é o que me contém. Confirmo que o amanhecer

é já um conflito antigo e ordenado, e que eu posso ser

personagem existente.

Fiama Hasse Pais Brandão 


\section{Contexto histórico-literário da obra de Fiama Hasse Pais Brandão}

Podemos falar em contexto do poeta enquanto autor e leitor de outros escritores, situado num determinado momento literário e social, capaz de filtrar ou rejeitar as vivências espacio-temporais. Por isso, escreveremos uma breve apresentação da Autora.

Em quase toda a obra de Fiama Hasse Pais Brandão (1938-2007), as estações, a luz, as mudanças nas árvores e flores, os pássaros relembram a quinta em que morou na infância e depois na maturidade, "Vivenda Azul", com o tanque, os caramanchões, a vasta gaiola contendo dezenas de periquitos, o lago com os peixes, os azulejos do terraço, em meio ao pomar, ovelhas, flores, perto do mar, em Carcavelos, Cascais, distrito de Lisboa.

A formação escolar e universitária despertou, em Fiama, um conhecimento das literaturas inglesas e norte-americanas e, mais tarde, da literatura germânica. Estudou no St. Julian's School, colégio inglês, de elite, em Carcavelos, o que lhe deu uma base para os estudos de língua e literatura inglesa. Frequentou o curso de Filologia Germânica na Universidade de Lisboa, até o terceiro ano, onde se familiarizou com as letras de língua alemã. Traduziu Robert Lowell e Novalis; Brecht, enquanto ainda estava proibido durante o governo salazarista; Cântico dos Cânticos, Artaud, entre outros.

O teatro esteve presente em sua formação como escritora, pois foi uma das fundadoras do Grupo de Teatro de Letras, junto com Luiza Neto Jorge, Gastão Cruz, José da Silva Louro e outros. Em 1965, o grupo surgiu na sequência do Círculo de Teatro de Letras, uma tentativa encoberta de criar uma associação de estudantes na faculdade, durante o Estado Novo, quando estas eram proibidas. Escreveu, por exemplo, Os chapéus de chuva, censurada, depois publicada em 1961. Ganhou o Prémio Revelação da Sociedade Portuguesa de escritores, por essa peça de teatro. A experiência no teatro lhe deu um olhar "cênico", que visivelmente se manifesta nos livros Área Branca e Cenas Vivas.

Gastão Cruz (2008, p.294) escreveu que 
as imagens iniciais da Fiama provinham, por um lado, de uma persistente leitura do teatro japonês, em que se inspiravam as 'Recitações Dramáticas', primeira parte de Em Cada Pedra um Voo Imóvel; por outro lado, do seu assíduo e demorado convívio com o mundo natural, os campos e o mar de Carcavelos, além do microcosmo que era a pequena quinta em que crescera.

Em Cada Pedra um Voo Imóvel, seu livro de estreia, datado de $1957^{2}$, ano que foi escrito, mas publicado em 1958, era um conjunto de poemas não em verso: poemas dramáticos e poemas em prosa, que não foram incluídos nas antologias posteriores, nem em Obra Breve (2006). Em 2008, Gastão Cruz editou os textos em prosa, incluindo esses sob o "belo título da sua obra de estreia" (Cruz, 2008, p.9).

Ganhou notoriedade com a publicação coletiva de Poesia 61, designação dada a um conjunto de cinco plaquettes de poesia, com a intenção de contribuir para a renovação da linguagem poética portuguesa. Poesia 61 reunia textos de Casimiro de Brito, Fiama Hasse Pais Brandão, Gastão Cruz, Luiza Neto Jorge e Maria Teresa Horta. Era uma revista/ movimento, nas dobras da capa de Poesia 61, figuram os nomes dos colaboradores por ordem alfabética, em primeiro lugar, o caderno de Casimiro Brito, que tem como título Canto Adolescente, dividido em dois conjuntos, o primeiro dá o título ao volume, formado por poemas em prosa, e o segundo, "Novos Telegramas", por poemas em versos breves, os dois têm 12 unidades cada. A plaquette de Fiama chamouse Morfismos, era composta por poemas numerados dentro de cada uma das seções: "Grafia", "Tema" e "Sincronia", perfazendo um total de 14 poemas. A plaquette de Gastão Cruz compunha-se de quinze poemas, divididos em quatro seções: "A morte percutiva", que deu o nome ao conjunto, "Nível", "Vestígios" e "Elegia"; a de Luiza Neto Jorge chamou-se Quarta Dimensão, um conjunto de oito poemas; e Tatuagem a de

\footnotetext{
${ }^{2}$ Em Pequeno Dicionário de Autores de Língua Portuguesa, em O Grande Livro dos Portugueses, de acordo com José Ferraz Diogo em Dossier Fiama Hasse Pais Brandão (21 out. de1992, p. 12) , consta que Fiama ganhou o Prémio Adolfo Casais por esse livro ( nos artigos da Internet também), na verdade, esse prêmio foi concedido a outra obra dela, O Texto de João Zorro(1974), uma antologia, com seleção de poemas de 61 a 70, e uma parte inédita.
} 
Maria Teresa Horta, um conjunto de três poemas, dois longos e um mais breve: "poema para a noite", "outubro" e "poema de insubordinação".

O contexto histórico em que surgiu Poesia 61 era um clima de medo e revolta: havia uma relação de causa e efeito entre a censura aos meios de informação, a vigilância da Polícia Internacional e de Defesa do Estado (PIDE) e o medo dos cidadãos. O ano de 1961 foi o sintoma cultural mais forte da crise que, treze anos depois, levaria à queda do regime salazarista. Se, por um lado, não devemos menosprezar as contingências histórico-sociais em que esses textos foram produzidos, por outro lado, é preciso ficarmos atentos às inovações de vanguarda que seus autores acompanhavam e praticavam, a fim de que não se imagine um estilo de época criado pela censura.

Uma boa compreensão do texto literário pressupõe o conhecimento do espaço físico e social em que foi produzido. Os textos de Poesia 61 têm uma atmosfera de morte e guerra que não deve ser esquecida. Politicamente, não há dúvida de que, na década de 60, os fatos decisivos da história de Portugal ocorrem em África ou a ela estão intimamente vinculados. Em 1961, Portugal enfrentou uma insurreição no nordeste de Angola e uma agressão militar da Índia. Por volta de 1968, 36\% do orçamento português era gasto com um exército de 149000 homens, ocupado em defender Angola, Moçambique e a Guiné contra guerrilhas independentistas.

Sobre a questão artística, a publicação de Poesia 61 foi um acontecimento no meio literário pela renovação de ideias e formas, contrapondo-se a um empolamento discursivo que caracterizava alguma poesia portuguesa de décadas anteriores, sobretudo a presencista e a neo-realista. Houve uma valorização da autonomia do discurso poético, uma espécie de "substantivação" da linguagem e recuperação da literalidade da palavra, conceitos usados pela crítica coeva. Para António José Saraiva e Óscar Lopes, em História da Literatura Portuguesa, a Poesia 61 representou a mais importante evolução conjunta da poesia experimental, em sentido tangente ao realismo social.

Assim como Fiama, Gastão Cruz e Luiza Neto Jorge frequentaram o curso de Letras da Universidade de Lisboa e a essa rigorosa formação acadêmica pode ser tributado o excelente domínio dos mecanismos da linguagem que encontramos nos textos desses poetas. 
Reis (2005, p.127) cita E. M. de Melo e Castro sobre a Poesia 61:

(...) está em causa então uma mudança radical da posição do poeta perante seus instrumentos de trabalho: a escrita e a linguagem. A poesia não é agora mais instrumento, nem retórico nem ideológico nem moral. A poesia, por outro lado, não é mais sentimento nem sentimentalismo. A poesia não narra, não serve, nem é mais discursiva. A poesia substantiva-se.

Como disse Eduardo Prado Coelho (1988, p.114), na Conferência proferida no Centre Culturel Portugais de la Fondation Calouste Gulbenkian, em Paris:

(...) até os anos 60 era relativamente fácil o agrupamento da nossa produção poética em termos de movimentos, escolas, caracterizações programáticas e revistas. Lembremos as referências obrigatórias a Orpheu, no princípio do século (que, aliás, para a nossa poesia, se inicia em 1915); à Presença (marcando os finais do anos 20 e os anos 30); ao neo-realismo e à colecção Novo Cancioneiro nos anos 40, que, no entanto, veriam ainda surgir como contraponto o espírito anti-ideológico dos Cadernos de Poesia; a revistas de índole diversa como Távola Redonda, Árvore, A Serpente, Graal ou Notícias do Bloqueio nos anos 50, embora todas elas anunciassem, com matizes ideológicos distintos, um retorno a uma certa autonomia do discurso poético; e ao movimento surrealista em Portugal.

A revista Orpheu (1915-1917), marco do Modernismo em Portugal, propõe questões pertinentes à linguagem, ao sujeito poético. Vivia-se um tempo de encruzilhadas.

Talvez o sentido da criação heteronímica consista em nos revelar, embora de um modo mais polémico, a possibilidade de o autor se distanciar suficientemente do texto para criar nele a dimensão de uma total objectividade, sendo este o aspecto da obra de Fernando Pessoa que se poderá admitir como mais determinante na evolução da poesia actual. (GUIMARÃES, 1989, p. 20). 
A despersonalização, uma das marcas do Modernismo, representa a impossibilidade de uma identificação, ou fusão, entre poesia e pessoa empírica e tem início em Baudelaire, segundo Hugo Friedrich. Essa despersonalização encaminha o texto para uma relativa autonomia respectivamente ao seu criador, aliviando a palavra dos vínculos ao contexto, possibilitando-lhe reforçados laços com a música e com a materialidade da palavra, de forma a levar Casais Monteiro a afirmar que "a libertação da palavra é o fenômeno mais marcante da evolução da poesia, de há um século para cá” (cit. in CRUZ, 2008, p.41).

Além da questão da heteronímia, a leitura de Pessoa impregnou as gerações seguintes, mas é possível afirmar que essa influência se altera, ou mesmo se reduz, com a geração de 60. Fiama Hasse Pais Brandão, segundo Eduardo Prado Coelho (1988), parece mais atenta em relação ao Pessoa, fundamentalmente no que diz respeito a dois aspectos: - a valorização física dos grafemas, o que a levou a protestar contra as atualizações ortográficas de textos de Pessoa e ao Pessoa de Mensagem, como aproveitamento da matéria histórica no texto poético, coisa que, em dado momento, acontece em Fiama.

Além da influência dos poetas de Orpheu, nos anos 20 surge a revista Presença, idealizada por José Régio que escreveu sobre Literatura Viva: "Em Arte, é vivo tudo o que é original. É original tudo o que provém da parte mais virgem, mais verdadeira e mais íntima duma personalidade artística." (Presença, 10 de março de 1927).

Para Régio, ou melhor, para a Presença, arte é o primado da subjectividade e da sinceridade sobre a linguagem, e o artista - ser excepcional - tem de ser visto no interior da sua individualidade, ao invés de ser analisado no interior da obra que produz. Numa palavra: escrever é igual a viver. O estilo é o homem. (SILVEIRA, 1986, p. 24).

Enquanto para Régio “a linguagem é um mal necessário", pois, incapaz de produzir literatura sem ela, o autor lamenta esse tormento e sua concepção de poesia está cindida em conteúdo e forma, com particular relevo para o primeiro desses 
elementos. Para Poesia 61, ao contrário, a palavra funda a poesia, busca-se a "autonomia da palavra", o que representa a procura de uma linguagem que se torna fundamentalmente substantiva. É a própria base da modernidade. Essa divergência no olhar fez com que a crítica presencista, na voz de João Gaspar Simões, não compreendesse a Poesia 61 e escrevesse, citado por Silveira:

Que toda a arte está hoje em crise, parece-me indubitável. Abstenho-me de afirmar o que às vezes pendo a crer: que atravessa um período de decadência, tendo vindo avançando num sentido cada vez mais completo de desumanização. Como hoje sucede, e é natural que suceda, particular relevo assumem nestes períodos as preocupações da forma, o gosto das extravagâncias afinal conducentes a becos sem saída, a substituição da inspiração pela técnica (ou da intuição criadora pelo intelectualismo) e as rebuscas de originalidade verdadeira. (cit. in SILVEIRA, 1986, p. 26-27).

Até os nossos dias ouvimos repercussão desse teor na crítica à poesia de Fiama e aos outros poetas de Poesia 61.

Termos como: "exigência de autenticidade", "reconciliação da poesia com a experiência humana", expressões divulgadas pelos presencistas, encontraram larga aceitação nos anos 50 .

Outro movimento literário importante dos anos 40 é o neorrealismo, que tinha uma posição contrária à dos presencistas. Alves Redol sublinha o momento em que, para a literatura portuguesa, era mais urgente combater o fascismo, implantado pelo golpe de Estado de 28 de maio de 1926, do que defender a "obra de arte".

O Neo-Realismo vai preocupar-se sobretudo em imprimir um conteúdo ideológico ou de conscientização política aos textos literários, a partir de supostos teóricos muito ligados ao Materialismo Dialético. No entanto, devido às circunstâncias políticas da época - dado que em Portugal vigorava um regime conservador e repressivo, desde a revolução de 1926 -, houve sempre a preocupação de disfarçar um pouco ou tornar 
implícitos esses pressupostos ideológicos, para se evitar a intervenção da censura ou uma possível apreensão de livros que pudessem ser julgados subversivos. (GUIMARÃES, 1989, p. 25).

Orientados pela concepção materialista da história, os neorrealistas se insurgem contra os modernistas de Orpheu e Presença. Para essa engajada poética, ambos os momentos anteriores representam uma postura alienada diante de um Portugal sob o fascismo.

Falta à concepção neo-realista da arte a passagem para a liberdade através da utopia, ou seja, através de um tempo e um espaço "inventados" em que a literatura pode antecipar o acontecimento histórico e ir à frente da realidade. Sem abdicar de um compromisso do seu tempo, o poeta investe na autonomia da escrita; ele sabe que, ao invés de uma relação especular com a realidade, há no texto a ocupação de um espaço de diferença, pois cada autor operacionaliza os instrumentos do mundo nos extremos da sua própria linguagem. Esta é a lição aprendida por Poesia 61. (SILVEIRA, 1986, p. 33).

Poesia 61 entendeu a poesia que não abdica do compromisso com o seu tempo, lição aprendida aos neorrealistas, mas investe na autonomia da escrita - lição dos modernistas; o poeta sabe que, ao invés de uma relação especular com a realidade, há no texto a ocupação de um espaço da diferença, pois cada autor operacionaliza os instrumentos do mundo nos extremos da sua própria linguagem.

Antes de chegarmos em 61, houve tendências renovadoras na poesia portuguesa, apontadas por Gastão Cruz, citadas por Jorge Fernandes da Silveira.

A partir de 1956, surgem as primeiras alternativas para a linguagem poética em vigor nos últimos anos 40 e nos primeiros 50. As folhas de poesia Árvore haviam sido, de 1951 a 1953, o melhor repositório dessa linguagem, em que a lição de Pessoa ou de Casais se cruza com as propostas do neo-realismo e do surrealismo. (cit. in SILVEIRA, 1986, p. 35). 
Vários fatores atestam a sua atualidade: o aparecimento ou a confirmação de poetas de agora e sempre (Sophia de Mello Breyner Andresen, Eugénio de Andrade, Egito Gonçalves, Ramos Rosa e outros); a divulgação de poetas estrangeiros de vanguarda e preocupados com uma visão social da literatura (Lorca, Vicente Alexandre, Éluard, René Char, Henri Michaux, por exemplo); a crítica inteligente de livros editados em português; os ensaios que analisam a especificidade da literatura sem qualquer dado anedótico sobre os textos ou a vida dos seus autores. (1986, p.37).

E poeta é aquele que pode dispor de um excedente da linguagem social e sabe transformá-lo em versos. Poesia é um jogo de tensões entre a experiência do olhar sobre a realidade extrínseca e a possibilidade de interpretar a diferença que se interioriza na produção de um trabalho sobre a linguagem. Esta nos parece a lição que Árvore legou à Poesia 61 no contexto poético português moderno e contemporâneo. (1986, p.39)

Fernando Guimarães escreveu que "a partir dos anos 40 há uma tendência renovadora que reage contra a influência então dominante dos presencistas e neorealistas". (GUIMARÃES, 1989, p.99).

Na passagem dos anos 30 para os 40, apareceram em 1940, Eu, comovido a Oeste, de Vitorino Nemésio e Nós não somos deste Mundo, de Ruy Cinatti; começa assim, a desenhar-se uma tendência onde se afirma o recurso à linguagem simbólica, à metáfora e à imagem.

$\mathrm{Na}$ poesia dos anos 50, repercutiu a libertação que o surrealismo significou em Portugal. Para Lourenço (1988, p. 205)

o poema surrealista é intrinsecamente des-centrado, ontologicamente "anônimo", não se contempla como um lugar vazio que dramatiza a sua ausência, mas celebra-se quase euforicamente como in-significante, in-transcendente, não-sério. Melhor do que ninguém, Alexandre O’Neill deu a essa “insignificância” do eu, sarcástica e ludicamente apreendida, um estatuto tão popular. Caberia a Herberto Helder conceber a realidade como uma monstruosa e magnificente Metáfora e o conjunto da realidade e das suas manifestações como um arquipélago de metáforas ao mesmo tempo organicamente oníricas e oniricamente orgânicas . 
Para Lourenço, a nova geração de poetas foi influenciada por essa concepção na poesia, por uma lado, e por outro, pela poesia de Ramos Rosa, "explorador incansável de um real próximo e inacessível." ( 1988, p. 205).

Nessa década, encontramos uma série de revistas: Távola Redonda, Graal, A serpente, Notícias do bloqueio, Cadernos do meio-dia, Árvore, entre outras. Árvore foi o órgão mais representativo da poesia de 50, segundo Gastão Cruz.

Poesia 61, publicação coletiva, está relacionada à intensa atividade desenvolvida em Faro por António Ramos Rosa e Casimiro de Brito. Ramos Rosa nasceu e morou em Faro, foi um "tutor" dos poetas colaboradores para a publicação. Gastão Cruz é natural de lá, mudou-se para Lisboa para cursar a Faculdade de Letras; Luísa Neto Jorge foi dar aulas no Liceu de Faro, no ano letivo de 1961-1962.

De acordo com Gastão Cruz, Poesia 61 começou em 1958, em outubro, começo do ano letivo da Faculdade de Letras. Então se conheceram ele, Gastão Cruz, Fiama Hasse Pais Brandão, e Luiza Neto Jorge. Fiama acabava de publicar Em cada pedra um voo imóvel. "os jovens poetas que viriam a afirmar-se no começo desta década procuravam definir sua linguagem sob o signo de uma renovada confiança no poder da imagem como elemento estruturante do discurso poético." (CRUZ, 2008, p. 289).

António Ramos Rosa teve um papel fundamental de divulgador e militante na defesa de uma nova poesia e da poesia moderna em geral - o que já fizera nas páginas de Árvore, entre 1951 e 1953, depois nos Cadernos do Meio-Dia (saíram três números em 1958: abril, julho e outubro; e em fevereiro de 1959, o número 4). António Ramos Rosa também foi responsável pelos volumes das coleções A Palavra e Sílex.

Houve plena interação entre esses jovens poetas e alguns poetas mais velhos que, em 1958 contribuíram com livros decisivos para esse processo de renovação: Sophia de Mello Breyner Andresen, com Mar Novo, Jorge de Sena, com Fidelidade, Alexandre O’Neill, com No Reino da Dinamarca, Eugénio de Andrade, com Coração do Dia, Ramos Rosa, com O Grito Claro. No ano anterior, 1957, o processo estava já em Pena Capital de Mário Cesariny e, após a explosão de 1958, Vitorino Nemésio, com $O$ Verbo e a Morte (1959), prosseguia com Cantata de Carlos de Oliveira, 1960. Muitos desses 
poetas colaboraram nos Cadernos do Meio-Dia. Foi aí que os jovens poetas tiveram contato com essa poesia; também saiu um fragmento do Canto Nupcial de Herberto Helder, que seria, quando integralmente publicado, O Amor em Visita. Eram exemplos dessa confiança num discurso poético revitalizado.

Ramos Rosa escreveu em 1953, no último número da revista Árvore:

A primeira coisa por que devemos lutar é pela confiança nos destinos da poesia, que nós confundimos com o próprio destino do homem. Um dos maiores perigos que ela hoje enfrenta (perigo aliás necessário, pois sem perigos não há aventura poética) é o que podemos chamar a aventura da pureza poética, a tentativa de criar uma linguagem onde a poesia cintile em cada palavra, em cada imagem, em cada verso. O seu hermetismo, que se combate superficialmente, é muitas vezes o nome que se dá à densidade, à riqueza, à liberdade, à imaginação ou à fantasia; numa palavra, ao especificamente poético. (cit. in CRUZ, 2008, p. 289-290).

De acordo com Gastão Cruz, este "perigo necessário" à "aventura poética" esteve na base das experiências poéticas mais enriquecedoras da poesia portuguesa.

Das imagens que fascinavam os nossos vinte anos se fez a nossa poesia - e, mais que todas as outras, a poesia de Fiama. Imagens que, olhadas depois de se ter olhado o sol, se transformavam: "Olho para o sol. E, depois, a areia fica coberta de rodelas encarnadas e verdes, e as barracas têm pintas encarnadas e verdes, e os garotos e os cântaros quando passam são encarnados e verdes.” A luz excessiva alucina, ver torna-se visão. (CRUZ, 2008, p. 295).

Fiama Hasse Pais Brandão "se concentrou num novo discurso poético, que é muitas vezes uma fusão ou uma sobreposição de discursos que se interpenetram." (CRUZ, 2008, p.346). Gastão Cruz afirmou que as buscas estilísticas e as incursões surrealizantes e experimentais de variada natureza confluíram com os intuitos de uma 
poesia realista - em certos momentos abertamente política, mas nunca, alheia ou desatenta às especificidades da invenção poética.

Essas questões se tornaram presentes nos primeiros poemas de Fiama Hasse Pais Brandão, depois a poética de Fiama seguiu caminho próprio, tendo a autonomia da linguagem como referência.

\section{A Crítica da Poesia de Fiama Hasse Pais Brandão}

Embora podemos contar com ensaios consistentes, ainda são poucos os estudos sobre a poética de Fiama Hasse Pais Brandão. A imprensa portuguesa apenas se manifestava por ocasião da publicação de algum novo livro ou em alguma efeméride. Citaremos primeiramente as publicações em livros, revistas ou jornais, com participações diversas:

- Em março de 2011, o número 2 da revista pessoa- revista de ideias ${ }^{3}$, homenagem a Fiama Hasse Pais Brandão, esse número é a publicação, na íntegra, das participações no Colóquio - Fiama Hasse Pais Brandão, em outubro de 2010, organizado por Gastão Cruz.

- Jorge Fernandes da Silveira reuniu ensaios seus sobre a poética de Fiama Hasse Pais Brandão publicados em um livro, denominado Lápide e Versão, de 2006.

- Em 2005, saiu a revista Metamorfoses $n^{\circ} 6$, uma homenagem a FHPB, há ensaios, depoimentos, antologia, fotos, cartas e uma bibliografia sobre a Autora. Essa revista é editada pela cátedra Jorge de Sena para estudos literários luso-afro-brasileiros, vinculada à Faculdade de Letras da UFRJ.

- Em 2001, a revista de poesia, Relâmpago $n^{\circ} 8$, foi concebida em torno de Fiama Hasse Pais Brandão. De acordo com o editor e os colaboradores,

\footnotetext{
${ }^{3}$ A referência completa das revistas e livros se encontra na Bibliografia.
} 
trata-se de "uma simples mas justa homenagem a alguém que ao longo dos últimos 40 anos soube construir uma obra não apenas singular, mas absolutamente única no panorama da poesia portuguesa.” Além de artigos e depoimentos sobre a obra de Fiama, há um relato dela sobre sua poética dos anos 60, com o nome de "A minha poética nos anos 60 ( memorandum talvez para os críticos)"״4.

- Um dossiê em Letras e Letras, uma edição especial desse jornal do Porto, sobre Fiama, em 1992. Além de artigos, há uma entrevista que Fiama concedeu a Rosa Maria Oliveira, respondendo a seis perguntas ${ }^{5}$. As respostas de Fiama eram versos de poemas ainda inéditos, foram publicados em Cenas Vivas, em 2000, com o título "Novas aventuras na caverna platónica", confirmando a convicção de Fiama de que a única entrevista está nos poemas.

- Fiama Hasse Pais Brandão escreveu um manuscrito, em 10/11/1991, denominado "A minha Poesia e referências literárias", divulgado durante o Colóquio - Fiama Hasse Pais Brandão - 29 e 30 de outubro de 2010.

- Em 1988, Fiama escreveu um depoimento em A Phala- um século de Poesia, uma edição especial, contando sobre o seu fazer poético; em 1989, Fiama deu uma entrevista para a mesma revista, por ocasião da publicação de seu livro Três rostos. Antes disso, quando foi publicada Poesia 61, os cinco poetas concederam uma entrevista para o Diário de Lisboa, publicado em 25 de maio de 1961. ${ }^{7}$ Houve outras colaborações de Fiama para revistas e jornais sobre outros poetas.

\footnotetext{
${ }^{4}$ Esse texto se encontra em anexo.

${ }^{5}$ Essa entrevista se encontra em anexo.

${ }^{6}$ Ver anexos. Agradeço ao Gastão Cruz por me mandar esse documento digitalizado.

${ }^{7}$ Ver anexos. Agradeço ao Gastão Cruz por me mandar esse documento digitalizado.
} 
- Em Homenagemàliteratura, publicado em 1976, Fiama Hasse Pais Brandão escreveu um prefácio à obra, em que refletiu sobre sua poética e reconsiderou 49 itens ${ }^{8}$.

- Há outros ensaios importantes sobre a poética de Fiama que saíram na revista Colóquio/ Letras e em outras publicações periódicas.

Passaremos a comentar algumas das produções mais significativas de ensaístas e críticos, que escreveram sobre a obra poética de Fiama com temas relacionados a esta tese:

- Gastão Cruz:

Um dos principais teóricos da poesia de Fiama Hasse Pais Brandão, poeta, companheiro de geração, ex- marido e pai de seus filhos. Escreveu:

Em “1958, as imagens: Fiama”, publicado em A Vida da Poesia - textos críticos reunidos, Gastão Cruz faz um apanhado do começo do encontro entre os poetas de sua geração, tendo como pano de fundo a Faculdade de Letras da Universidade de Lisboa. Pontua a importância das imagens para essa geração, e informa que alguns também se empenharam nas artes plásticas, como Luiza Neto Jorge.

Escreveu que as imagens fascinavam a todos, nos seus vinte anos, "se fez a nossa poesia - e, mais que todas as outras, a poesia de Fiama" (Cruz, 2008, p.295). Achavam que era de imagens que a poesia vivia. Camilo Pessanha, Cesário Verde, Sá- Carneiro e Pessoa foram tutelares; depois Sophia de Mello Breyner Andresen, António Ramos Rosa, Mário Cesariny e Eugénio de Andrade.

Percorreu os livros de Fiama desde Em cada Pedra um Voo Imóvel (1958) e o Aquário (1960). O primeiro é um conjunto de poemas dramáticos e poemas em prosa e o segundo são poemas em prosa ou uma só longa prosa poética, pontuados por imagens. Segundo ele, Área Branca (1978) revolucionou "decisivamente o imagismo primitivo, conduzindo-o a um transe, do qual o retorno só poderia ser a um mundo em

\footnotetext{
${ }^{8}$ Esse prefácio, que está em anexo, foi expurgado na 1ª̣ edição de Obra Breve, 1991, e não foi reeditado.
} 
rearrumação progressiva, aos Cantos do mesmo real, revisitado, às cenas vivas de outro tempo e de agora, no lugar do início.” (2008, p. 295). Até em livros mais recentes de Fiama, com base em visões simples do real, "cada vez mais as imagens retomam intensamente o seu papel de componente do real". (2008, p. 296).

Finaliza com uma reflexão sobre A Matéria Simples (2000), um conjunto de quatro poemas, que tem a epígrafe camoniana "E o vivo amor de que sou feito/ Como a matéria simples busca a forma.". Gastão Cruz conclui que a poesia dela "regressa ao lugar donde porventura nunca terá saído - o das imagens essenciais da descoberta do mundo: 'a noite', ‘o aquário', ‘as minhocas', ‘os limões', ‘a jarra'...” (2008, p. 296).

Em "Fiama: Obra Breve ou o Som do Poeta", Gastão Cruz confirma o poder da imagem como elemento estruturante do discurso para toda a geração e para outros poetas um pouco mais velhos. Compara um poema de Em Cada Pedra um Voo Imóvel com o poema Grafia I de Obra Breve9, que fora publicado em Morfismos (1961), plaquete publicada em Poesia 61. Diz que ambos esboçam uma mesma concepção da linguagem poética, como forma de "despir objetos", de "derrubar arestas". "Para que a palavra (a poesia) principie, é preciso que as palavras sejam 'densas de sangue'. Esta consciência da densidade das palavras afasta uma tal arte poética de qualquer tentação de formalismo." Conclui que a poesia de Fiama "mais não fez que aprofundar as relações entre a linguagem e o mundo, entre as palavras e a vida, entre as imagens linguísticas e as imagens reais.” (2008, p. 291).

O livro Três Rostos (1989) tem três partes: Âmago II (Nova Natureza), Poemas Revistos e Arómatas e Ecos. Em Âmago II (Nova Natureza), há um poema no qual Fiama retoma o primeiro verso de "Grafia I": “Água significa ave” transformando-o: "Água significa ave isto él a forma de exprimir a parte mínil ma das essências. Diminuir a área da/ imagem.”. (BRANDÃO, 2006, p.476).

Entre um verso e outro, medeiam talvez vinte e quatro ou vinte e cinco anos. A partir dessa constatação, Gastão Cruz propõe em: "Três Rostos de Fiama Hasse Pais Brandão ou uma "Neofiguração do objecto sedutor" em A Vida da Poesia, que há em

\footnotetext{
${ }^{9}$ Obra Breve teve duas versões. A primeira é de 1991 e abrange toda a obra poética de Fiama até Três Rostos (1989). A segunda é de 2006 e contém toda sua obra poética.
} 
ambos os poemas um esboço de teoria poética, e que, pelo menos em parte, não se alterou.

Esta desocultação do real, esta busca da essência e da nudez das coisas ('diminuir a área da imagem') é, afinal, aquilo que, mais profundamente, a poesia persegue. Só assim pode ser verdade que a sobreposição do significado das imagens simultaneamente aumente e reduza a área de cada uma delas. A este paradoxo se refere, talvez Fiama (...). Porque não há presença mais falsa que a do real na poesia. Porque não há presença mais verdadeira que a do real na poesia - o real absoluto? (CRUZ, 2008, p. 286-287).

Gastão Cruz levanta, nesse mesmo artigo, uma questão fundamental da poética de Fiama: a complexa relação entre o interior e o exterior do poema, dizendo que "nenhum poeta português se mostrou ou mostra tão consciente desta questão central como Fiama." (2008, p. 287). Às vezes, o poema é o menos imediato, o mais distante, o que está fora, enquanto a natureza é a proximidade, o dentro, o imediato. Por vezes, existe a tentativa de anular essa distância, menor ou maior, entre o real e o texto, entre a evidência e a evocação.

Outra questão apontada no livro Três Rostos é a das sensações. Acredita que nunca (até então), talvez em "Nome Lírico", a poesia de Fiama foi tão assumidamente lírica, pois nele as sensações ocupam o primeiro plano do texto. As emoções tornam-se a base da metáfora, da produção de analogias. Além do paradoxo entre o interior e o exterior do texto, a emoção é a fonte de sua energia mais profunda.

Gastão Cruz, quando da publicação de Obra Breve (2006), distinguiu, na poética de Fiama, algumas fases, dois grandes períodos: o que abrange as décadas de 60 e 70 e tem seu apogeu em Área Branca (1978), tempo de intensa criação verbal, que procurava fundir uma visão da arte e da natureza; e os anos 80 e 90, que começa com os dois Âmagos (tem como subtítulos Nova Arte e Nova Natureza) e vai progressivamente tendendo para uma "descomplexificação" da linguagem, que atingirá o seu limite em As Fábulas e A Matéria Simples. 
Em um depoimento, publicado na revista Relâmpago $n^{\circ} 8$, Gastão Cruz demonstrou insatisfação com a crítica literária em relação à obra dos grandes poetas que ficam, segundo ele, "na prateleira da incompreensão ou do esquecimento." Referia-se a Cenas Vivas de Fiama. Já se havia colocado em relação a Área Branca publicado em 1978, que passou despercebida pela crítica, com a exceção de Luís Miguel Nava que escreveu um artigo profundo sobre essa obra.

Gastão Cruz ainda escreveu uma análise de um poema desse livro, “Quando eu vir vaguear por dentro da casa", poema 39, de Área Branca, publicado em Século de Ouro - antologia crítica da poesia portuguesa do século XX (2002). Concluímos, em sua análise, que esse poema é uma teoria da realidade, e, em parte, esse é o título do poema de Cenas Vivas (2000), que analisaremos.

Em pessoa - revista de ideias, Gastão escreveu um breve depoimento "Sobre Fiama - uma síntese”, passa por alguns aspectos pessoais e poéticos de Fiama.

- Jorge Fernandes da Silveira

É, até o presente momento, no Brasil, o mais importante estudioso de sua obra; sua dissertação de mestrado foi sobre a poética de Fiama e a tese de doutorado sobre a Poesia 61.

Jorge Fernandes da Silveira escreveu vários artigos, ensaios e entrevistas sobre a obra de Fiama Hasse Pais Brandão. Em 2006, reuniu-os em um livro: Lápide e Versão (já comentado), título inspirado na obra da autora, nos versos de O Texto de Joan Zorro: “(...) O progresso dos textos/ é epigráfico. Lápide e versão, indistintamente.”

O livro é dividido em três partes: "Lápide e Versão"; "Lápide" e "Versão". A primeira parte é a apresentação da autora e a transcrição de duas entrevistas: uma, que deu a Ana Marques Gastão quando do lançamento de Obra Breve, saiu em "Diário de Notícias", em 7 de julho de 2006 e a outra, por motivo da divulgação de Verso com verso, em 2003, da editora Angelus Novus.

"Lápide", a segunda parte, é um capítulo da sua Dissertação de Mestrado: $O$ Inscrito e o Escrito: uma leitura da Poesia de Fiama Hasse Pais Brandão (1974), e uma versão revista (1995) da sua Tese de Doutorado: Portugal Maio de Poesia 61 
(1986). São ensaios que mantêm a cronologia. A primeira parte é uma leitura do livro (E)ste Rosto (1970). Jorge conclui que "o discurso de Fiama Hasse Pais Brandão fará do obstáculo não uma constatação da inutilidade dos empreendimentos humanos, mas sim algo inerente à estrutura do real.” (2006, p. 49).

No segundo texto, Jorge Fernandes da Silveira faz uma espécie de mini-roteiro poético de Fiama. Começa por "grafia 1", o primeiro texto de Morfismos, livro com o qual Fiama participa da publicação coletiva Poesia 61. É um poema dialético; há treze versos escritos com arte poética e rigor de quem formula um teorema. O primeiro versoestrofe apresenta a potencialidade das palavras "água" e "ave". "Ave" e "água" são as imagens que constroem o espaço poético do sujeito que vê a realidade e escreve o poema. O "se" habita o vácuo. Está no intervalo. "este modo hipotético de estar entre a realidade do mundo e a realidade do poema é uma constante na poesia de Fiama." (2006, p. 56). Dois dos mais recorrentes recursos em Morfismos são o paralelismo e o cruzamento entre a construção das imagens.

Jorge Fernandes da Silveira diz que Fiama é poeta eminentemente visual. O seu texto é transbordamento do olhar. "Os olhos são o lugar onde residem as formas reais do poema." (2006, p. 62).

Outra questão importante que Jorge Fernandes da Silveira aponta nesse ensaio é em relação à intratextualidade. Diz que o texto volta-se sobre si mesmo, para construir a sua própria intratextualidade. E o que caracteriza o estilo de Fiama é a relação entre figuras e imagens.

"Versão", a terceira parte do livro, são 30 anos de ensaio, apresentados em ordem regressiva, do presente para o passado (2006 - 1976).

"Agora é Inês-Constança" é uma leitura comparativa da "Inês de Castro" de Camões, "Inês de Manto", poema de Fiama, com o epílogo de "Noites de InêsConstança”, peça de Fiama Hasse Pais Brandão. Relaciona-a com a história portuguesa, aproximando-a de Brecht, de acordo com a leitura do crítico.

O ensaio intitulado 'Sobre 'A Roupa', Do Mundo, Vulcão: Fiama, Herberto, Nava" é uma leitura aproximativa dos poemas "A Roupa" de Fiama, publicado em Cenas Vivas, mas que já havia sido publicado em 1994, na Colóquio/Letras $n^{\circ} 131$; com 
um poema de Herberto Helder de Do Mundo (1994) e com um poema de Vulcão, de Luís Miguel Nava, também publicado em 1994. Um processo de interlocução entre esses três poetas. Escreveu sobre o poema "A Roupa” em “Alta Costura: 'A Roupa' de Fiama".

Estudou os Poemas Galaicos e o poema ibérico "Modo Histórico da Cidra", apresentou esse trabalho na Galiza, em 2005. Jorge Fernandes da Silveira confirma o "epigráfico" dos textos de Fiama, e, justifica que, "por ser epigráfico, o progresso dos textos ao avançar, olha para trás" (SILVEIRA, 2006, p.113). Conclui, relacionando o poema "Modo Histórico da Cidra" de Fiama, que escreveu no dia do aniversário dela, ao "Aniversário" de Álvaro de Campos.

Em "Da Idade da Pedra", Silveira escreveu que, numa primeira Fiama, - e está pensando em seus primeiros poemas - "reside um resto de 'ficção' poética que julga ter o compromisso de mudar o mundo, transformando-o porque o traz para dentro de si, como se a margem, o microcosmo, buscasse dar ao centro, o macrocosmo, o seu equilíbrio.” (2006, p. 128).

Fez uma leitura de Barcas Novas (1967), primeira coletânea individual de poesia. Relacionou o poema que dá título ao livro à cantiga. Reforça a presença da intertextualidade e intratextualidade nos textos de Fiama. Escreveu que a poeta apresenta o início da história das navegações e da expansão colonialista como uma autora "a serviço de uma arte dramática não-aristotélica", com influências de Brecht, que estava traduzindo. "Faz com que o leitor nela veja um sujeito de mediação entre ele e o acontecimento, entre o presente e o passado, a fim de que ambos possam ser vistos por meio de uma estratégia discursiva em que a interação entre os sujeitos de diferentes épocas esteja em estado de permanente interlocução." (2006, p.141). Jorge Fernandes da Silveira percebe o sentido de proporção na poesia de Fiama.

Jorge Fernandes da Silveira fez também uma leitura de "Sumário Lírico", poema de Cenas Vivas.

- Luís Miguel Nava

Em 1985, Luís Miguel Nava escreveu um artigo sobre Área Branca, aclamado pela crítica e por Gastão Cruz. 
Quando leu Área Branca, Luís Miguel Nava ficou fascinado, o que o fez escrever o ensaio: "Os Poemas em Branco de Fiama Hasse Pais Brandão" em Ensaios Reunidos (2004). Pelo ineditismo da proposta, não se ouviu quase nada sobre Área Branca, de acordo com Nava. Começou sua análise enfatizando a luminosidade do texto. Depois salientou a multiplicidade de planos que se interceptam e confundem. "A luz, o espaço, a visão, a perspectiva, todos estes termos são - supõe-se - suscetíveis dum emprego metafórico, possuem todos eles um sentido literal e um sentido figurado, entre os quais é precisamente posta em causa a existência de qualquer demarcação.” (2004, p. 220). Fiama subverte a linguagem, o sentido figurado e literal, que convencionalmente é idêntico à verdade. Tomamos por verdade um sentido condicionado por processos de que nós próprios somos produtos e nos escapam. “À ideia segundo a qual há, por um lado, o mundo e, por outro, o seu sentido, opõe-se pois aqui o mundo enquanto sentido." (2004, p. 220).

Nava escreveu que Fiama faz referência à natureza, - na esteira de Caeiro -, em relação à qual se posiciona em perspectiva idêntica à que adota face a uma certa ideia da cultura e da História, por um lado, e da própria literatura, por outro. Faz relação entre a poética de Fiama e a de Francis Ponge.

Afirma que Área Branca tenta levar a cabo dois projetos que acabam por se unir num só: introduzir no poema a fantasia e o sonho; e aproximar o poema do objeto plástico. Qualquer projeto realista embate contra esta aporia. Só dando um salto para outro nível é possível contorná-la. A esse outro nível, Fiama vai procurar chegar por intermédio do conceito de fantástico. Luís Miguel Nava conclui: "os olhos chamam a si o papel da boca, sendo o acto que eles levam a cabo o de sorver ou mastigar. Ou seja, o que eles em Área Branca entregam ao espírito é um produto digerido, transformado interiorizado, em suma; o que, se dermos conta de que 'a interiorização/ é um acto de apropriação do abstracto’ (cf.38).” (2004, p. 225).

- Rosa Maria Martelo

Escreveu o ensaio "Fiama e a "fala perfeita" que está em Em Parte Incerta Estudos de Poesia Portuguesa Moderna e Contemporânea (2004). 
A partir de uma entrevista que Fiama concedeu ao Diário de Lisboa, em maio de 1961 (citado anteriormente), em que a poeta caracteriza sua poesia, Martelo (2004, p. 175) sublinhará a singularidade de Cenas Vivas, e a qualidade poética desta obra em si mesma, "a importância que se reveste no contexto de uma poesia que se reescreve em absoluta maturidade e num processo de auto-superação integradora do passado da obra."

Martelo continua: "O que pretendo dizer é que o olhar raso procurado em Cenas Vivas tem por detrás uma elaboradíssima experiência de leitura e de escrita que o subordina ao conhecimento de poesia, à vivência quase corporal dos sons e dos sentidos.” (2004, p.182).

- Eduardo Lourenço

Eduardo Lourenço escreveu Fiama ou o inelutável, em 1991, publicado como prefácio de Obra Breve, em 2006. Outro artigo significativo de Lourenço é "Senhora do silêncio ou a poesia do imemorial”, publicado em pessoa - revista de ideias, $\mathrm{n}^{\circ} 2$, de 2011. Nesse artigo, disse que "a inesgotável realidade do mundo sensorial, sensível, não verbalizado, foi a musa de Fiama".

\section{- Pedro Eiras}

Pedro Eiras, em "Poética das Sequóias Gigantes - sobre a poesia de Fiama Hasse Pais Brandão" (2001), escreveu, a partir da imagem das sequóias gigantes, uma possível leitura da poesia de Fiama. O ponto inicial, além da imagem da árvore é o verbo dizer, e diz que na poesia de Fiama "se fundem num só a árvore, o tempo e o poema". Esse ensaio foi publicado na revista Relâmpago $n^{\circ} 8$, em 2001. Escreveu também "Quatro palavras para recomeçar a ler Fiama”, publicado em Relâmpago $n^{\circ} 19,2006$, sobre a Obra Breve, publicada em 2006.

Em pessoa - revista de ideias, n², 2011, Pedro Eiras escreveu "Fiama - a escolha da terra", faz uma leitura do poema "Novas aventuras na caverna platônica", do livro Cenas Vivas de Fiama.

\section{- Joana Matos Frias}

Escreveu “Às vezes as coisas dentro de nós - figuras inconsúteis no teatro da memória de Fiama”, publicado em pessoa - revista de ideias, n², 2011. Vale ressaltar 
que, de acordo com Frias, "Fiama aprisiona assim os contornos da memória com a mão que escreve, o que vem alterar de forma decisiva a composição dos planos da memória e, muito em particular, a natureza da relação entre o vivido e o visado.” (2011, p.95).

\section{- João Amadeu Oliveira da Silva}

João Amadeu Oliveira da Silva em seu ensaio, "A poesia de Fiama Hasse Pais Brandão - um modo de tratar a realidade por tu" (2004), faz rapidamente um percurso poético de Fiama, a partir de Em cada Pedra um Voo Imóvel. Detém-se em Cenas Vivas, separa o texto por temas significativos na poética de Fiama.

\section{- Maria Teresa Dias Furtado}

Maria Teresa Dias Furtado escreveu um artigo em Colóquio/ Letras $n^{\circ} 94$ (Nov. 1986) sobre Área Branca: “'Área Branca', de Fiama Hasse Pais Brandão - O Elogio do Belo e a consciência da história". E escreveu um testemunho: "Da Poesia" em Relâmpago $n^{\circ} 8$, em 2001 e o ensaio "Fiama tradutora. O‘fluxo azul”" em Metamorfoses 6, 2005.

- Fernando J.B. Martinho

Escreveu "A Erma Visão" em Relâmpago no 8, 2001 e "Fiama: um canto de epifania" em pessoa - revista de ideias, nº2, 2011.

- Carlos Mendes de Sousa

Escreveu "Na sabedoria de uma quietude: Três Rostos de Fiama" in Relâmpago n`8, 2001 e “Âmago: o mar âmago" em pessoa - revista de ideias, $\mathrm{n}^{\circ} 2$, sobre a seleção que alguns autores, amigos e críticos, fizeram dos poemas de Fiama para a antologia Âmago, lançada por ocasião do Colóquio - Fiama Hasse Pais Brandão.

- Fernando Guimarães

Colaborou com a Relâmpago $n^{\circ} 8$ com o artigo "Fiama Hasse Pais Brandão: silêncio e vida interior".

- António Ramos Rosa 
António Ramos Rosa escreveu algumas críticas sobre Fiama principalmente sobre suas primeiras obras, em “(Este) Rosto de Fiama Hasse Pais Brandão, que foi publicado em A Poesia Moderna e a interrogação do Real - II e "Fiama Hasse Pais Brandão ou o espaço da infinidade", publicada em Incisões oblíquas - estudos sobre poesia portuguesa contemporânea.

- Eduardo Prado Coelho

Escreveu "Apresentação de um livro: '(Este) rosto"”, publicado em A palavra sobre a palavra e "Fiama Hasse Pais Brandão: poesia e escassez", publicado em $O$ reino flutuante, foram os primeiros textos sobre a poética da Autora. 


\section{Capítulo 2}

A "Fala perfeita" de Fiama Hasse Pais Brandão - um itinerário da poesia da Autora

Aquela muralha começa a ser objecto

da escrita. Desloco-a.

Fiama Hasse Pais Brandão

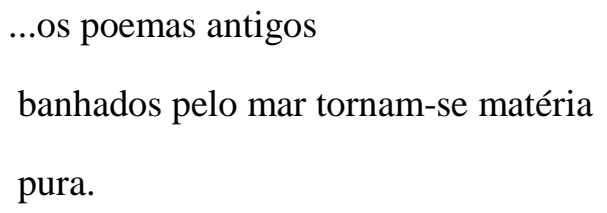

Fiama Hasse Pais Brandão 
Como vimos no capítulo anterior, a poesia de Fiama Hasse Pais Brandão está associada à Poesia 61. Seu percurso poético começou em 1957 com o livro Em cada pedra um voo imóvel, publicado em 1958, assume visibilidade a partir da década de sessenta, com a plaquete Morfismos, incluída no livro Poesia 61, onde como o próprio título sugere, há preocupação com a forma ou, como nos diz Fiama, "Morfismos, uma designação que sugere a 'poética' que os informa. $O$ que na criação poemática me interessa é realizar uma 'forma' verbal, que possua qualidade estética específica, isto é, poética." ${ }^{10}$. Continua: "A 'forma' poética é, pois, a destruição do hábito linguístico e dos estatutos de correspondência vocabular, embora a palavra autônoma não se constitua poema gratuitamente.” (BRANDÃO, 1961, p.14).

Para acompanhar esse pensamento de Fiama, recuperaremos alguns conceitos fundamentais do Modernismo, por exemplo, a ideia de "ostinato rigore" de Leonardo da Vinci que foi divulgado por Mallarmé e Valéry. Ítalo Calvino, em Seis Propostas para o próximo milênio, escreveu: "Paul Valéry é a personalidade que em nosso século melhor definiu a poesia como tensão para a exatidão. Refiro-me principalmente à sua obra de crítico e ensaísta, na qual a poética de exatidão segue uma linha que de Mallarmé remonta a Baudelaire, e de Baudelaire a Edgar Allan Poe.” (1993, p.81). A partir desse traço, vinculamos a poesia de Fiama a uma tradição de poetas que trabalham a palavra com precisão, por exemplo, os poetas Paul Valéry, João Cabral de Melo Neto. No âmbito português, Sophia de Mello Breyner Andresen, entre outros. Assinalamos uma origem de uma poética não seu ponto final.

Na minha dissertação de mestrado "No Poema": um paradigma da tessitura poética de Sophia de Mello Breyner Andresen, já havia afirmado:

Outros poetas buscam um rigor artístico e uma precisão ao "escolher as palavras para estarem no poema. Sophia atribui um grande peso ao trabalho artesanal consciente, esse aspecto nos mostra uma linhagem da poeta, é herdado da poesia simbolista, aliás, a revolução simbolista despertou uma aguda consciência da linguagem, Baudelaire retomou essa ênfase dada por Poe e a transmitiu a Mallarmé e Valéry. O poema se torna uma transformação do arbitrário em necessário. ( STEINBERG, 2006, p.50).

\footnotetext{
${ }^{10}$ Palavras de uma entrevista com Fiama Hasse Pais Brandão, em maio de 1961, publicada em Diário de Lisboa, em 25 de Maio de 1961, p.13 e 14. Ver anexos.
} 
Esse rigor que se quer numa determinada poesia, na poética de Fiama resvalou para a poesial substantivo. Fiama se aproxima dessa tradição da modernidade e descreve a evolução de sua atividade poética durante a década de 60: de uma única imagem avassaladora fundada quase numa única palavra, passa para a consciência da existência do eu lírico e finalmente para a realidade, correspondendo a uma sequência do substantivo para o nome e deste para o verso, escreveu em "A minha poética nos anos 60", em Relâmpago 8 (BRANDÃO, 2001, p.109 -112). Usa como argumento o primeiro verso: "Água significa ave" ou "O substantivo é audível/ como de cada vez um óvulo.” (2001, p.109). São versos do primeiro livro, ou plaquete, Morfismos.

Com relação à materialidade da palavra e do processo estético, o crítico Eduardo Prado Coelho (1972, p.265) entendeu isso como uma ruptura com a tradição presencista que, por sua vez, se mostrou incapaz de ter acesso a um fazer poético que exigia um ato efetivo de leitura e nesse sentido criticou severamente a poética ligada ao grupo Poesia 61.

Compartilhando a importância da autonomia do discurso poético na modernidade, Augusto de Campos escreveu:

O que caracteriza a condição do poeta moderno não é tanto a objetividade exteriorizante ou a introspecção lírica mas a autonomia do discurso poético, permitindo uma descontinuidade experiencial que bloqueia tanto o confessional como o convencional e induz a uma poesia-crítica, neutralizadora do sentimentalismo e da autocomplacência típicos do Romantismo na sua dimensão mais vulgar. (CAMPOS, 2006, p.255).

Ou seja, Fiama, em seus primeiros livros, se inscreve na modernidade na medida em que preza a autonomia da palavra. Ao olharmos para sua poética, desde os primeiros versos, lemos uma poesia que, embora não desvalorize o eu poético nem a tradição, não se permite o confessional, nem o convencional e induz a uma poesia metalinguística, que sempre se volta para a linguagem e, mais do que isso, para a própria poesia. 
A poeta desenvolveu, em "Teoria da Realidade - tratando-a por tu", a ideia da "fala perfeita", questão fundamental em sua poética que será abordada no próximo capítulo. Neste, estou procurando fazer uma ponte entre dois momentos extremos da obra de Fiama: de um lado o poema “Grafia 1"(1961) e, de outro, o poema que foi publicado em Cenas Vivas (2000). Portanto, um poema da primeira fase e outro da última fase de seu fazer poético. "Recomeçar pelo começo sempre novo, pela leitura de tais modos de significação tendo como horizonte último os últimos livros: Cenas Vivas, As Fábulas, A Matéria Simples, doravante de um só livro, extremo fôlego, unidade." (EIRAS, 2006, p.195). Questionaremos o quanto a "fala perfeita" de Fiama está filiada ao conceito de poésie pure de Mallarmé, herdado do Simbolismo, pelo qual o Modernismo tinha em grande apreço.

Se pensarmos que poésie pure é entendido em sentido amplo como "toda lírica que não pretenda ser sentimento e reação aos conteúdos do mundo, mas jogo de linguagem e da fantasia" (FRIEDRICH, 1978, p.136), é insuficiente para compreendermos toda a poesia de Fiama, mesmo que se leve Mallarmé às últimas consequências, por meio das contrações extremadas em Morfismos (1961). Os caminhos de sua obra poética diferem por serem traçados inclusive existencialmente. Quando entendemos a poésie pure "cujo valor não reside nos conceitos, e sim no som das palavras e em sua capacidade de evocar imagens" (ARGAN, p.149), poderemos aproximar da poesia de Fiama, ao poema do primeiro livro que chamaremos de inaugural:

\section{Grafia $1^{11}$}

Água significa ave

se

a sílaba é uma pedra álgida

\footnotetext{
11 O poema "Grafia 1" pertence à plaquete Morfismos, publicado em 1961. A data e a página mencionadas ao final do poema são da Obra Breve - Poesia Reunida, de 2006. Sempre que possível citarei a data que o poema foi publicado e a referência em Obra Breve.
} 
sobre o equilíbrio dos olhos

se

as palavras são densas de sangue

e despem objectos

se

o tamanho deste vento é um triângulo na água

o tamanho da ave é um rio demorado

onde

as mãos derrubam arestas

a palavra principia

(2006, p.15)

Consideramos esse poema como uma arte poética que dialoga com Mallarmé. O primeiro verso já nos mostra a autonomia da palavra, a força do som, não descartando seu significado e suas inúmeras possibilidades, as palavras incham de significados, de imagens e de sons, não se restringindo ao seu uso segundo o senso comum.

Como citado acima, Fiama escreveu um depoimento sobre sua poética que vale a pena reproduzir:

Comecei palavra a palavra. Assim: Água significa ave ( $1^{\circ}$ verso de Morfismos, 61) ou $O$ substantivo é audível/ como de cada vez um óvulo ${ }^{12}$.

A poesia estava quase numa única imagem avassaladora, que coincidia com uma única palavra. Tão avassaladoras que eram totais, uma a uma. (...). Uma palavra em equilíbrio com o seu referente imagético/ verbal. Quase sempre equilíbrio de sons: assonância, ecos, ritmos sincopados mínimos repetidos. E a obsessão visual, um êxtase, mais do que uma metodologia estilística. Sim, da estrutura gramatical emergiam seres

\footnotetext{
12 Esse verso está em "Sincronia 4", poema do mesmo livro Morfismos de 1961. Em Obra Breve - poesia reunida, de 2006, está na página 22. (Notas do autor).
} 
verbais quase biologicamente iniciais e vivos (de cada vez um óvulo): água era um substantivo: um ente de substância verbal e imagética. Era, pois, uma poética do substantivo e, pela soma das presenças desses entes e suas significações (água significa ave), a poética de um léxico, no sentido próprio. (BRANDÃO, 2001, p.109) ${ }^{13}$.

Água significa ave nos mostra como

cada signo implica o outro: convoca-o, ocupa-o, transmuda-se nele. Se água significa ave é porque tudo significa tudo. Uma arte poética, mas que se transforma (significa) uma arte de vida. (EIRAS, 2006, p.196).

Toda água significa a ave, e esse significar significa a própria significação, quer dizer, qualquer palavra poética diz imediatamente toda a poesia. (2006, p. 197).

A água, diz a primeira lição, é plural. Aquela que significa ave terá ainda outros significados, esquecidos, recuperados, nunca idênticos. (2006, p.195).

Esse primeiro verso nos aponta para movimento, metamorfose - tanto dos vocábulos, das palavras, como de seus significados e significantes e até de temas. Sugere sempre uma peregrinação, também em relação ao tempo e ao espaço, como veremos. Esse primeiro verso aponta-nos para o movimento das palavras, dos sons e dos significados.

Fiama, nesse primeiro projeto poético, questiona a própria linguagem. Como escreveu Eduardo Prado Coelho (1988, p.115), essa geração reativou no campo poético certa pulsão política, "não em termos que secundarizem o discurso no plano de mero instrumento, mas em termos que promovem a autonomia do discurso poético, a afirmação primordial da materialidade do processo estético".

\footnotetext{
${ }^{13}$ Esse depoimento de Fiama foi publicado na revista Relâmpago no8, 2001, foi escrito à mão e assim publicado. Invés de usar os versos sublinhados optei pelo itálico. (ver anexo).
} 
A partir dessas considerações iniciais, voltemos ao poema. Jorge Fernandes da Silveira fez uma leitura aprofundada de "Grafia 1", em Portugal Maio de Poesia 61 e reeditada em Lápide e Versão; recorreremos a ela, sempre que necessário.

Percebemos um rigor no aspecto visual do poema, anterior mesmo à leitura, só pela visualização no papel. Primeiro um verso inaugural, seguido da conjunção se, isolada, transformada em verso, realçando assim o significado de hipótese; depois temos dois versos, intercalados pelo se; e, finalmente, o advérbio onde remetendo a um lugar, introduzindo os dois versos que finalizam o poema.

A relação inesperada entre duas palavras de significados diferentes aproxima-se pela sonoridade e pelo $a$ inicial. É um verso transgressor porque é uma afirmação inesperada, ousada. Como analisou Silveira (2006, p.53):

Numa escrita racional e lógica, a motivar-se nova e não conforme, a 'grafia' organiza o sistema de signos da língua como um jogo de correspondências entre significados diferentes, elaborando, assim, a tese de quem manipula a ruptura da norma dos padrões sócio-lingüísticos e, também, poéticos.

A correspondência entre água e ave é inesperada, quebra a expectativa do leitor que precisa criar novas relações, o verbo significa enfatiza o estranhamento por trazer significado preciso, do campo da razão.

A relação entre os verbos ser e significar conceitua os fundamentos de uma poética contrária às formas congeladas pelo uso, na hipótese extraordinária de sua verossimilhança em devir. (SILVEIRA, 2006, p.54).

Ao traçar as continuidades das linhas, a "grafia" as divide em quantidades descontínuas de significações. Grafados assim, insólitos e exatos, "se" e "onde" impulsionam a verticalidade metafórica (o vôo) a "ascensão por água", quer dizer, de “água significa ave". (2006, p.54). 
Ave e água são as imagens que constroem o espaço poético do sujeito que vê a realidade e escreve o poema. (2006, p.55).

Em resumo: quando se significa como "se", o objeto nomeado já habita in limine o vácuo. Ele está no intervalo. Vácuo, intervalo ou pausa: estes domínios da propriedade do entre definem a literatura.(2006, p.56).

Este modo hipotético de estar entre a realidade do mundo e a realidade do poema é uma constante na poesia de Fiama. (2006, p.56).

$\mathrm{Na}$ terceira estrofe, o sujeito poético nos chama para a página da escrita, nos conscientizando do espaço, da concretude da escritura e o nosso olhar repousa na horizontalidade dos versos. Há uma relação com Mallarmé que, nas palavras de Blanchot (2005, p.349), "dotou o homem de uma experiência nova: o espaço, origem criadora e aventura do movimento poético."

Inesperadamente o sujeito poético compartilha uma tensão entre a racionalidade e certo distanciamento, com um verso carregado de paixão que mostra sua força na palavra sangue, contrapondo-se ao adjetivo álgida. A emoção demonstrada está relacionada às palavras, assim como álgida caracteriza uma pedra, que é o predicativo de sílaba; estamos no âmbito da palavra, do verso, do poema. Então, como escreveu Mallarmé, citado a partir de Blanchot (2005, p. 347): “'Toda emoção sai de nós, alarga um meio ou em nós funde e o incorpora.' A emoção poética não é, pois, um sentimento interior, uma modificação subjetiva, mas é um estranho fora no qual fomos jogados em nós, fora de nós.”. Ou seja, pode parecer um poema frio, mas, ao contrário, nos coloca próximos à emoção da criação poética.

A geração, que ficou conhecida pela publicação de Poesia 61, tinha como preocupação a afirmação de que a emoção existe no poema, este não é frio e distante do sujeito poético, contrapondo-se à ideia de distanciamento. Não estamos nos referindo a derramamento de emoções, ou a sentimentalismo; é a emoção da palavra poética. Gastão Cruz (1999, p.168) escreveu que assim como Fiama, Eugénio de Andrade, na mesma época escrevia, "em Mar de Setembro: 'diremos terra ou mar/ ou madressilva,/ mas sem música no sangue/ serão palavras só,/ e só palavras, o que diremos.' 'Música no sangue', 'densas de sangue' - condição para que cada palavra não seja só uma 
palavra, para que água possa significar ave." Ou seja, para essa geração, a paixão é condição para a existência da poesia.

O crítico continua sobre a última estrofe de "Grafia 1":

Esta desocultação do real, esta busca da essência e da nudez das coisas ("diminuir a área da imagem") ${ }^{14}$ - desígnio tão presente nos poemas de Três Rostos - é, afinal, aquilo que, mais profundamente, a poesia persegue. Só assim pode ser verdade que a sobreposição do significado das imagens simultaneamente aumente e reduza a área de cada uma delas. (CRUZ, 1999, p.169).

Água é a palavra inicial do poema e é a única que começa por maiúscula, ocupando o papel principal, trazendo as qualidades desse elemento para o poema, principalmente, a volatilidade e a transformação, qualidade do que não tem forma fixa; com isso chegamos à ave, que tem por principal atitude o voar, locomover-se, mudar. Chegamos à sétima estrofe onde a palavra triângulo nos remete através da imagem à ave (AV), ou como escreveu Jorge Fernandes da Silveira (2006, p. 65): "A forma do triângulo vive na palavra ave, pois a representação gráfica dos seus dois primeiros fonemas sugere-me a forma do triângulo: AV. Afinal, a relação entre figuras e imagens caracteriza o estilo de Fiama Hasse Pais Brandão.”

O tema principal do poema é o papel do fazer poético, ou seja,

importa mais o ato de escrever do que a subjetividade do praticante da ação. O que é, no fundo, uma forma de fingimento. (...) o texto volta-se sobre si mesmo, para construir a sua própria intratextualidade. (...) Quando a forma se expõe em dimensões rigorosas ("tamanho"), as imagens produzem nexos entre signos lingüísticos semanticamente descontínuos: a força geometricamente incomensurável do "vento" e a forma geometricamente comensurável do "triângulo". (SILVEIRA, 2006, p.63).

\footnotetext{
${ }^{14}$ Um verso do poema "Quod Nihil Scitur" in Três Rostos (1989); em Obra Breve (2006, p. 476).
} 
Portanto há um jogo de correspondências, "num texto que se ordena em movimentos contínuos de equivalências, 'o tamanho deste vento' imagem de 'triângulo na água' contém resposta à pergunta sobre a disposição dos versos nas proposições condicionais". (2006, p.64).

O poema é construído por equivalências antagônicas, tanto em significados como em forma: "pedra álgida" contrapõe-se a "densas de sangue", o adjetivo álgida relacionado a pedra, por um lado, e densas de sangue, portanto quentes e viscerais, relacionadas a palavras, por outro; a relação entre vento e triângulo, enquanto vento é incomensurável, o triângulo é uma forma concreta e definida. A intratextualidade está presente em toda a obra de Fiama, desde o poema que se volta sobre si mesmo até versos inteiros em outros poemas, como, por exemplo, "Água significa ave isto é a forma de exprimir a parte míni-/ ma das essências." (BRANDÃO, 2006, p. 476), verso de "Quod Nihil Scitur" de Três Rostos (1989). Num mesmo poema, os versos debruçam-se uns nos outros, esse movimento também se forma em relação à obra como um todo.

Em suma, "água significa ave" é o sintagma gerador de todas as transformações ocorridas no poema. E os versos finais explicitam o processo revolucionário de produção de "grafia". (SILVEIRA, 2006, p.65).

As questões sugeridas pela poeta não se reduzem aos poemas indicados, nem apenas à fase, são experimentações que percorrem toda Obra Breve - poesia reunida. Importante é analisarmos de onde partiu sua poética para uma leitura mais abrangente de qualquer poema da autora.

Depois desse primeiro momento e da plaquete lançada em 1961, Fiama publicou Barcas Novas (1967). Ao comentar sobre essa fase de sua poética, disse: "Então, senhora do nome, aquiesci perante mim, que vivia, como Eu lírico.” (BRANDÃO, 2001, p. 110).

A proposta da autora é explorar o eu lírico ou sujeito poético (usado neste trabalho), mas, antes, precisou ser/ estar "senhora do nome": 
um nome surge. Não puro dado da experiência sensorial, não memória imagética, não material bruto da vivência ou da gramática, que é a primeira organização poética da palavra. Mas sim o de uma fase filosófica: a palavra água torna aparente a visão da ave, que só existia agora, pensada, e dita, um nome. Disse, em Barcas Novas, 66: 'Esta manhã/ hojel é um nome. Mas podia ter dito: Esta águal hojel é um nome. (BRANDÃO, 2001, p. 110).

Para refletirmos sobre nomear e o sujeito lírico, proporemos o poema "O Nome Lírico" in Barcas Novas (1967).

\section{O Nome Lírico}

Esta manhã

hoje

é um nome

Nem mesmo amanheceu

nem o sol

a evoca

Uma palavra

palavra só

a ergue

Com um nome

amanhece

clareia

Não do sol

mas de quem

a nomeia

(2006, p.49) 
O poema gira em torno de nomear a realidade e a realidade em si, representada pelo amanhecer real - o real é o mundo empírico, enquanto o nomear pertence ao poeta e ao poema. Quando o poeta nomeia, apropria-se. A palavra nomeada pelo poeta é realidade e experiência para o poema.

Há uma contraposição entre a palavra nomeada "Esta manhã/ hoje/ um nome"; e a situação real/ natural: "Nem mesmo amanheceu/ nem o sol a evoca" e a força poética está na palavra e no nomeá-la: "Com um nome (manhã)/ amanhece ( a coisa se faz)/ clareia. O dia clareia, não por obra do sol, mas do sujeito poético; por isso o título do poema: "Nome Lírico". A discussão não é sobre a beleza ou não da manhã, da natureza, do mundo externo, mas sim da força da palavra. ("Do verbo fez-se carne” Jó I,14). Da palavra fez-se a imagem da manhã e fez-se o poema, e quem fez isso, foi aquele que nomeou, o poeta.

Através do nomear o objeto, no caso, a manhã, se torna presente. Estamos na realidade do poema, é um metapoema. O poeta fundou a manhã nesse poema, nomeando-a. Não é mítico, apenas acontece, aconteceu nesse poema.

Não é o "dizer sobre", próprio do conhecimento, mas "um deixar dizer a partir do poema".

É um poema conciso, com versos curtos, às vezes apenas uma palavra, como hoje, o que torna presente, traz para o agora a impressão desse momento efêmero.

Em "A minha poética nos anos 60 (memorandum talvez para os críticos)", Fiama lembrou-se do poema "Pedra em Expansão", dizendo: "Então, senhora do nome, aquiesci perante mim, que vivia, como Eu lírico. Estou a recordar-me da:" (BRANDÃO, 2001, p. 110).

\section{Pedra em Expansão}

Diz não são os anos que passam

é a pedra 


\author{
Não o tempo \\ o que por mim passa \\ mas ela \\ que somente acompanha \\ Diz não passam anos \\ para a minha idade \\ só uma pedra está
}

(2006, p.52)

O que no poema inicial de Fiama foi proposto em relação aos nomes: expandi-los e não confiná-los em significados fixos, aqui, no título desse poema, supõe-se expansão do nome, do objeto, da pedra, que ganha características outras que não as convencionais. A expansão se realiza em relação ao significado e às suas características e também ao significante que se alonga na característica surpreendente que é nomeada. A poeta manipula uma ruptura da norma e dos símbolos convencionais. É uma forma de relativizar a ordem do discurso. O tema, embora concreto, sofre uma abstração, modificando profundamente a nossa percepção e o nosso entendimento.

Pedra que tem como característica convencional a inércia, aparece em expansão, se alonga e adquire qualidade de mutabilidade, de movimento e metamorfose. Expande a ideia da pedra, do tempo e do sujeito poético ou eu lírico (denominado pela poeta). Movimento e mutabilidade perpassam todo o poema, contrapondo a característica da imutabilidade da pedra, como signo convencional. Como disse Jorge Fernandes da Silveira (2006, p.123), Fiama lança termos que vão escrever as imagens que reivindicam um efeito novo de real entre a figura autoral do poeta e as coisas. "O movimento é a única qualidade essencial” (BRANDÃO, 2008, p.55). Silveira (2006, p.124) complementa: "Porque, como escreve Fiama, leitora de Hölderlin, 'O movimento é a única realidade essencial"'.

A expectativa é quebrada na primeira estrofe, depois do espanto inicial do título. Uma expressão convencional modificada pelo advérbio de negação, "não são os anos que passam", é substituída pela "pedra" - em lugar dos anos, que, convencionalmente passam, temos a pedra que passa. Temos duas possibilidades que interagem e 
intercalam: a primeira é em relação ao tempo - os anos que passam, refere-se ao tempo que passa, o referente é o ser vivo; na transformação dos anos em pedra, relacionamos à passagem física, deslocamento no espaço, o ser vivo assiste à passagem da pedra.

A segunda estrofe acentua a questão entre o tempo e o espaço. O referente é o sujeito poético que é espectador. A cena fica congelada, o tempo não passa por ele, mas a pedra o acompanha, se está junto deslocam-se juntos; a questão passa a ser espacial, ou continua a ser espacial, confirmando a afirmação da primeira estrofe.

A terceira estrofe retoma o primeiro verso, com modificações significativas, invés de "Diz não são os anos que passam"; "Diz não passam anos" e no próximo verso, "para a minha idade", justificando e restringindo a expressão convencional, finaliza com um verso inesperado que se alonga no espaço porque não há sinal de pontuação: "só uma pedra está", confirmando a característica adquirida da pedra - de ocupar um espaço. Até o último verso estava em deslocamento e nesse permanece, está, tem um lugar, por pouco tempo porque o verso ficou em aberto.

Lembraremos um poema que podemos ler como uma poética - está em um livro posterior Era (1974), onde a poeta contrapõe a mutabilidade da pedra e da grafia: "menor mutabilidade aparente da pedra/ e da maior mutabilidade da grafia".

\section{O Texto de Joan Zorro}

Levando ao limite, homenagem, o gesto da escrita, posso atribuir os meus textos a joan zorro. Existimos sobre o anterior. O movimento da escrita e da leitura exerce-se a partir da menor mutabilidade aparente da pedra e da maior mutabilidade da grafia. O progresso dos textos é epigráfico. Lápide e versão, indistintamente. 
A forma lembra prosa, os versos são longos e irregulares, há discussão do fazer poético. Fiama termina essa reunião colocando questões fundamentais para lermos seus poemas. A presença da homenagem - homenagem à literatura (nome de um dos seus livros) - e cita a influência direta de Joan Zorro, um trovador medieval, não apenas a inspira mas atribui a ele "o gesto da escrita". A questão não se resume à presença dele ou da poesia medieval na poesia de Fiama, o sujeito poético refere-se a Joan Zorro como o "escritor" dos seus textos. Não há a negação do sujeito, a morte do autor, mas há referência a um outro olhar para essa questão, um alargamento desse sujeito. E o sujeito se torna plural: "Existimos sobre o anterior". O passado também se estende, abarca tudo o que é anterior, tendo como imagem Joan Zorro, sua poética e sua época histórica. Por um lado, há diálogo com a tradição, por outro, rompe com ela na forma, alonga os versos, assim alarga a ideia da lírica e a aproxima da prosa.

Duas questões importantes se apresentam aqui: a memória literária e o sujeito poético, marcado nas terminações dos verbos poder e existir, no plural, portanto inclui outros autores e os leitores.

Por vezes, entreguei mesmo explicitamente os meus textos a outro autor que amei, por exemplo, o poeta medieval Joan Zorro. Um dos meus livros intitula-se $O$ Texto de Joan Zorro. Abundam, pois, nos meus poemas, os títulos e as referências classizantes, bíblicas, anglo-germânicas, e, sobretudo, portuguesas, homenagem à minha profunda matriz nacional. Assim, um título de um dos meus livros é Homenagemàliteratura. (BRANDÃO, 1991, p.4).

Contrapõe a pedra à grafia, enquanto a primeira é a metáfora, por excelência, da imutabilidade, por oposição há a grafia que é mutável. Na poesia, há esses dois movimentos, que a fundamentam. "Lápide e versão" - o que fica registrado, inclusive no lugar da morte, e o movimento da vida. Fiama registra assim sua poética, o spunto, a semente de sua obra poética. 
E, citando-me: 'Escrevemos sobre o anterior...', 'Lápide e versão, indistintamente', isto é, 'Nous écrivons sur l'anterieur'..., 'Pierre de tombe et version, à la fois'. L'ecris sur l'anterieur, quer dizer, sobre os poemas e depois dos poemas, já escritos. O anterior ou é uma lápide (tudo está aí, fixo) ou, então, uma versão, uma interpretação, em mim, para sempre. (BRANDÃO, 1991, p.5) ${ }^{15}$.

Fiama escreve sobre sua poética em 1991, utilizando versos desse poema que foi publicado em 1974. A poeta faz desses versos uma das matrizes de sua poética.

Em relação à imagem e ao movimento de mão dupla (mobilidade e imobilidade), há o título do livro "Em cada pedra um voo imóvel" (recitações dramáticas e poemas em prosa), 1958, que, com o mesmo título, foi reeditado no conjunto de seus textos em prosa, em 2008. Há outra ocorrência da ruptura dos gêneros literários que podemos perceber no subtítulo, denominação das duas partes que compõe o livro.

Outro poema posterior, que aproxima "pedra em expansão", é "Poética do eremita”, que está em Três Rostos, de 1989.

Poética do Eremita ${ }^{16}$

No deserto estão secas as pedras que no mar

se molhavam. A semelhança confunde

o eremita que solitário de mais passou

o tempo entregando-o à isolada memória.

Aqui, a pedra seca, para o eremita,

não perdeu a qualidade húmida

de poder ter estado ao pé do mar.

(2006, p. 534)

\footnotetext{
${ }^{15}$ Este texto é manuscrito e está em anexo.

${ }^{16}$ Este poema foi musicado por Adriana Calcanhoto em 2009.
} 
A expansão é colocada em relação ao tempo e ao espaço, abrangendo dois lugares opostos: o mar e sua qualidade úmida, por outro lado, o deserto e sua secura. Em relação ao tempo, parece que o lugar é o mesmo, o que mudou foi o tempo: anteriormente era mar, hoje é deserto. Para o eremita, através da memória, a mesma pedra conserva a qualidade que anteriormente tinha, a "de poder ter estado ao pé do mar". "Passa para o eremita essa capacidade de vislumbrar por detrás da realidade superficial os elementos que unificam a realidade - mar e pedra." (SILVA, 2004, p.286). São resíduos de uma tradição. A realidade estendida é captada pela memória, encontrando na pedra a qualidade úmida.

A memória tem um papel fundamental na poética de Fiama, assim como veremos em “Teoria da Realidade - tratando-a por tu”, do livro Cenas Vivas (2000).

Podemos pensar que a memória é uma expansão do sujeito. Ao pensar a memória, visualizamo-la expandida, não a restringiremos à memória pessoal com características únicas de um sujeito, pensemos como estendida no tempo e no espaço, assim como o eremita que percebe a qualidade úmida da pedra.

Voltando a Mallarmé e ao conceito de poésie puré, Fiama declara que o poeta francês a despertou para uma poética ideológica, ao mesmo tempo em que percebeu a importância da forma e do espaço na poesia; percebeu o movimento poético.

Os contemporâneos, na esteira de Mallarmé - o poeta dos caligramas e da fragmentação verbal - ensinaram-me o que designo por ideologias poéticas, que assimilei temporariamente e depois abandonei. (...). Na época das ideologias, digo, a minha poesia sofreu um tempo de rarefacção verbal, uma perda da língua. Porém, rapidamente, a força do classismo das grandes epopeias, do grande lirismo bucólico, aliada à força da tradição anglo-germânica (sem esquecer os grandes poetas americanos) e ao vigor da tradição portuguesa venceram, uma vez mais e de novo, a ideologia passageira do poema construído em si, matéria verbal. Desse diálogo, ou talvez monólogo, isto é, de tudo o que foi escrito e lido por mim, são testemunho permanente e inevitável, os meus poemas. (BRANDÃO, 1991, p.3). 
Fiama abandona o Mallarmé das ideologias poéticas onde sua poesia sofreu um tempo de rarefação verbal, uma perda de língua, como ela disse. Se, em um primeiro momento, a leitura que a poeta faz de Mallarmé a leva a essa rarefação verbal, em outro, ou, na leitura que fazemos de Obra Breve, percebemos que o que Fiama assimilou do poeta francês é a "aventura do movimento poético", citado por Blanchot sobre Mallarmé. "O espaço como aproximação de um outro espaço, origem criadora e aventura do movimento poético" (BLANCHOT, 2005, p.349). Mesmo a rarefação verbal se transformou em liberdade semântica, linguística e espacial, pensamos o espaço como o da página e como espaço geográfico e histórico. Apesar da verbalização da poeta em ter abandonado a poética mallarmaica, ela tem consciência que seus poemas são testemunhos permanente e inevitável de tudo o que escreveu e leu.

Se, para Mallarmé, a teoria de sua poética foi nomeada de poésie puré, para Fiama, sua poética denominada em "Poesia da realidade - tratando-a por tu" de "fala perfeita".

Para compreendermos o percurso poético de Fiama e em como chegou à questão do real e desenvolveu sua própria teoria da poesia, é importante citar outro trecho do texto manuscrito: “A partir de então, desde Coral de Sophia de Melo Breyner, comecei a poder conhecer e ver o real e as coisas de uma forma poética. E desenvolvi a própria teoria da poesia.” (BRANDÃO, 1991, p.2). Partiu desse livro de Sophia, que o leu ainda jovem, onde o real é a matéria do poema, é vivo e movente. Atravessou o caminho que descreveu e continua a nos contar sua trajetória poética.

"Descoberto o nome e o eu lírico, os enunciados pessoais, chamados poemas, tornaram-se potencialmente infinitos. Os ritmos mais eufonicos e um pouco cantantes. (...). Passados mais dois anos após a descoberta do nome; ele sim, depois, identificador dos entes: 'O mesmo nome/ tem uma casa ou um vale/ entre montes', (de Barcas Novas, 67) é uma reiteração filosófica da anterior asserção empírica "Água significa ave”". (BRANDÃO, 2001, p.110 - 111). 
Casa ou um Vale

Serra de Portoalegre

Aqui tudo

é casa ou um vale

porque uma casa entre montes

é funda

De tão profunda é um vale

e a mesma água

que corre

tem o leito

nessa casa

ou de igual forma

no vale

O mesmo nome

tem uma casa ou um vale

entre montes

E sendo fundo

é um leito e

nele

a mesma água deito

(2006, p.54)

A partir da observação de uma paisagem, de uma realidade empírica, os nomes são ditos como identificadores dos entes. A partir da observação, ou ao longe, as coisas se confundem, ou significam outras coisas. Aqui a ênfase está na questão da 
profundidade, sugerida pela perspectiva da visão, o adjetivo preponderante é funda/o e profunda/o, que reitera a ideia e sonoridade do primeiro. A autora brinca com os significados das palavras: leito nessa casa nos direciona para a cama, mas, em seguida, ampliamos o significado para o solo no fundo do rio e surpreendentemente o eu poético deita água no rio. O espaço é visto ao longe até a última estrofe, onde a paisagem se torna próxima, ao alcance da mão e dos versos.

Enquanto "Água significa ave”, a relação, a princípio, é feita pela sonoridade das palavras, para, num segundo momento, ampliarmos a imagem que essas palavras sugerem; a relação entre casa e vale, no presente poema, se estabelece através da imagem que visualizamos a partir da paisagem descrita pela autora: vemos ao longe um vale, que pode ter/ conter uma casa. Tanto nesse poema, quanto no primeiro, citado o primeiro verso, as imagens são ampliadas; aqui em relação ao espaço, lá aos nomes que ampliam seus significados. É o espaço do poema e forma aqui se refere também ao espaço da página. Estamos entre a realidade do mundo e a realidade do poema.

Em relação ao nome diz: "O mesmo nome/ tem uma casa ou um vale/ entre montes", a proximidade dos nomes se dá pela visualização da cena (a forma, os contornos da cena) e pelos adjetivos fundo/profundo, e ainda, pelo nome leito, que foi explorado em significados, inclusive abordando a utilidade.

Notamos a adjetivação de gênero em: "De tão profunda é um vale/ e a mesma água que corre", portanto, profunda deveria caracterizar um substantivo feminino, nesse verso, caracteriza vale, substantivo masculino, então, profunda é a casa que por estar entre montes parece um vale, é funda, profunda.

A cena representada - uma casa ou um vale e um rio - uma cena bucólica que não sintetiza o poema, esse se expande para outros significados que têm a forma como referência, portanto podemos falar em metalinguagem, ou um poema que tem como tema o fazer poético, em aparente contraste com a cena bucólica. É um poema com rimas e repetições de expressões e versos, o que nos lembra o eco, presente numa cena bucólica. Não queremos propor prioridades, mas sim inserir significados, sem contrapôlos. Há o tema bucólico inserido ao tema do fazer poético.

Esse prolongamento, ou expansão, precisou marcar inclusive os versos: 
expandindo-se dos êxtases coisificados (61) até à consciência da nomeação e do sujeito, que já memoravam pequenas cenas e paisagens (67), chegou pela sua avidez e pela aceleração infinita do sujeito quando vive, até ao discurso poético literalmente discursivo, longo, enunciativo e confessional. (BRANDÃO, 2001, p. 111).

Fiama continua sua exposição em relação ao seu fazer poético, e constata que os versos se alongaram, encompridaram, enquanto o sujeito poético tornou-se enunciativo. Oferece-nos como exemplo o poema "Matinal".

Como de Poesia se tratava, o que ficou longo e enunciativo, ao desencadearem-se o nome e o sujeito em cumulações confessionais, foram os versos. Para caberem nos poemas, os meus nomes e o meu sujeito tiveram de alongar os meus versos em 69. Recordo-me o que disse então: comecei assim um verso intitulado Matinal, por exemplo: (BRANDÃO, 2001, p.111-112).

\section{Matinal}

Não é o mar que nos oculta ou reconduz esses navios, os de sextantes, da renascença, para além deste coração plácido, mas a própria terra, a que contém a elevação das árvores, em corte ao vivo, em serrações,

estas marés dos campos (sedimentos) vulneráveis, estes vários ocasos, turíbulos, os da névoa (que une o que é diverso; noite e o dia). Sem que no mar nada perpasse ou dele regresse ou aí figure longe do olhar humano, completa a sua memória, o narrador, à sua beira, bebi as águas inomináveis, porque demais nomeadas, por muitos dias, dentro do pensamento no completo silêncio, sem quaisquer chuvas, gotas, então ouvi: não é como na renascença esse mar 
o ouro enigmático: mas a terra e todo o sistema

(isotérmico) do ar, os interstícios (fenda a fenda)

de um objecto, o olhar lançado para além

deste (o coração) ainda plácido, e logo, com a mudança, perturbado,

a do ar fluido do inverno em sinal do estio, do ocaso em claridade

(matinal), a imutável mudança, a dos signos da terra.

(2006, p.116)

Não só os versos tornaram-se mais longos, mas também a lírica adquiriu características da narrativa. Assim, os primeiros versos nos trazem aspectos da memória coletiva, da história e o sujeito histórico está presente a partir da metonímia coração, órgão do corpo humano, responsável essencial para a vida e, na poesia, metáfora de sentimentos. Ele é plácido. A questão da narrativa é confirmada pela menção explícita ao narrador, no oitavo verso, que se manifesta e adquire uma voz em primeira pessoa.

O título "Matinal" traz um motivo discutido em "O Nome Lírico": é o mar, ou também, o frescor a que o título nos remete.

Ao mar se contrapõe a terra. O mar das histórias, das lembranças, da renascença, das viagens. "Não é o mar que nos oculta ou reconduz esses navios, / (...)/ mas a própria terra, a que contém a elevação das árvores, em corte ao vivo, em serrações,". Há antíteses entre o mar e a terra; entre coração plácido e perturbado; ocaso e matinal; imutável e mudança. E, na expressão do narrador: inomináveis e demais nomeadas. A presença de um narrador marca uma ruptura de gênero e a apresentação de outra voz emaranhada ao poema ${ }^{17}$.

\footnotetext{
17 Em relação à ruptura dos gêneros literários, Fiama radicalizou essa experiência quando deu uma entrevista a Rosa Maria Oliveira, no "Dossier Fiama Hasse Pais Brandão", para "Letras e Letras" em outubro de 1992, em que respondeu às perguntas com versos de "Novas aventuras na caverna platônica" do livro Cenas Vivas (2000). Afirmou, com isso, que a única resposta a essas perguntas estava nos poemas. (Esta entrevista está em anexo).
} 
Embora o mar nos remeta ao movimento é a terra a eleita para ser contemplada, ou será de onde o ponto de vista do sujeito poético partirá. Existe um movimento dado pelas marcas de tempo (inverno e estio; ocaso e manhã), o movimento não é constatado no momento, aparenta ser imutável, diferentemente do que ocorre com o mar, que está em constante movimento. O mar, nesse poema, remete ao passado, aos resíduos de uma tradição. O sujeito poético escolhe um lugar, a terra, que está relacionada ao presente.

Há nesse poema uma eleição do real, presente na terra e no sistema isotérmico do ar, contrapondo uma imagem ilusória à que o mar pode trazer aos olhos do sujeito poético, o mar da renascença: "na renascença esse mar/ o ouro enigmático", o distante.

Nos poemas de Fiama, há um movimento entre a realidade empírica e a realidade do poema. É uma rua de mão dupla; por um lado, refere-se à realidade e por outro, escreve sobre a matéria poética, a poesia, o papel, a página. Esses elementos também têm uma realidade, talvez a mais pungente.

A questão da mutabilidade é discutida no poema citado acima "O texto de Joan Zorro", do livro Era (1974): "o movimento da escrita e da leitura/ exerce-se a partir da menor mutabilidade aparente da pedra/ e da maior mutabilidade da grafia." São conservados os versos longos, e a contraposição se faz entre a pedra e a grafia. $\mathrm{O}$ adjetivo caracteriza cada um dos elementos. Assim como os versos de um poema que se dobram e desdobram, os poemas também. Podemos relacioná-los a um jogo de espelhos, em que os versos se espelham e reproduzem mil imagens diferentes.

Depois da longa imersão do narrador ("por muitos dias"), "dentro do pensamento", ouviu que "não é como na renascença esse mar/ o ouro enigmático: mas a terra e todo sistema/ (isotérmico) do ar," Ou seja, houve uma escolha depois de muita reflexão ou meditação: a opção foi pela terra. Decidiu-se, em "Matinal", que a matéria poética pertence à terra, "a dos signos da terra" em contraponto ao mar, ao mar da renascença, a um mar estagnado, das relíquias, dos resíduos, que não pode mais ser matéria poética, não é o mar que pertence à natureza mas o mar da história, carregado de esperanças, de ouro, que foi nomeado demais.

Enquanto Mallarmé quer se distanciar da realidade empírica, como escreveu Blanchot (2005, p.330), pois "a poesia não responde ao apelo das coisas. Ela não está destinada a preservá-las, nomeando-as", a matéria poética de Fiama pertence à terra, ao 
real e próximo, embora não descarte os resíduos e a memória. Vamos aprofundar o olhar de Fiama para essa questão.

Embora no poema "Pormenores vivos de Mallarmé e Antero" há menção a dois poetas, não há uma leitura de suas obras, a não ser pela questão das palavras prolongadas, unidas conforme o som, o que é uma menção superficial a Mallarmé e, em relação a Antero, menciona o fato que para ele o pensamento visual era inferior. A coincidência entre os dois poetas, embora tão distantes em suas poéticas, pertencem à mesma geração, mas em espaços distintos. Nasceram no mesmo ano, Mallarmé nasceu um mês antes de Antero e Antero morreu três anos depois de Mallarmé, no mesmo mês ${ }^{18}$. Fiama conversa com a tradição e escolhe esses contemporâneos tão diversos. Como escreveu a poeta "quando leio um Poeta, vou absorvendo sua teoria do real, e sua expressividade e os seus sentimentos." 19

Pormenores vivos de Mallarmé e Antero

Uma horta com vários pormenores vivos maçãsbolbosfigos remoinhos de asas zumbidos. Uma hortanooutono juncada de parras caídas atravessada de caulesde aveias mortoscomopalhas.

Insectos ignorantes como besourosmoscasvespas. Outros indiferentes como zângãos e sobretudorápidos ruidosos as-

\footnotetext{
18 Antero Tarquínio de Quental (Ponta Delgada, 18 de Abril de 1842 - 11 de Setembro de 1891) e Stéphane Mallarmé (18 de Março 1842 - 9 de Setembro de 1898).

${ }^{19}$ Manuscrito exposto durante o Colóquio Fiama Hasse Pais Brandão - 29 e 30 de outubro de 2010. (ver anexos).
} 
cigarras. Tudo demasiado clarose procuro o matizvago entre estee

aquele ser. A união entre os fonemas que representam os tonsnaturais.

Levar a transformação atérever os pilaresvivos ${ }^{20}$. Digo a interlocutores que a cultura é figurada. Uma horta que passapordentro deum versode Mallarmé é da mesmanatureza que adeoutrosversos que euli em (Este) Rosto. Releio osmeustextos para mereencontrar

noestilo nafrase nadescrição da evolução dos sons que representam osignorantes. Anelídeos bolasde terraarenosa aparentes. As hastes de trigo que pareceminquebráveis sujeitas à nitidezdaluz. Tudotão íntegro quando a nitidez corresponde à dos fonemasrepletos de figuras. Quintaprofunda esotérica com a grandeza das tona-

\footnotetext{
${ }^{20}$ Baudelaire, « La Nature est un temple où de vivants piliers... " (nota da autora).
} 
lidades. De uma formaoposta

à de Antero paraquem opensamen-

tovisual era inferior. Eunão oi-

ço compureza. Diluem-se vários

volumesnosváriossons como

fileira depilares seiadiluin-

do na borda das áleas. Estarnap-

oesia francesa e na quinta queé

um reino de insectos permanentesob-

cecantes emlinhasespirais

Azeitão, 1977

(2006. p.253 - 255)

Notamos uma tensão entre os versos e as palavras que se prolongam, o que aponta para uma quebra da tradição, aspecto levantado já por Mallarmé; por outro lado, há um rigor formal - cinco versos em cada das oito estrofes, versos que seguem alguma métrica, seguem uma tradição, portanto ideias antagônicas no mesmo poema, se, por um lado, respeita a tradição, por outro, radicaliza na expressão das palavras que se alongam no espaço. De qualquer maneira o espaço da folha é respeitado, e a sonorização dos vocábulos também, o que requer uma leitura expressiva. As palavras demandam um desdobramento e há um aspecto lúdico. Dentro das estrofes normativas em que o poema se comprime, com rigor, as palavras refletem-se umas nas outras até não ter mais sua cor própria, mas serem somente as transições de uma escala musical, o que nos lembra Mallarmé, de uma forma menos radical porque elas não perdem o significado convencional.

Sobre a forma, com palavras que se alongam e se continuam, Fiama escreveu em “Do Prefácio de Cântico Maior”, em 1985:

O que me emociona: o texto que cabe na pupila: o simultâneo, a grande cena das metáforas e das comparações, a Visão multiforme do Conhecimento (pus no coração a 
Sabedoria de Ezra), que é parcelar nas palavras e nas imagens e que só por acumulação diurna e através da absorção pupilar (como a do ar) tende para o Todo. (BRANDÃO, 2006, p.741).

Ou seja, no poema "Pormenores vivos de Mallarmé e Antero", Fiama antecipa essas palavras. $\mathrm{O}$ aspecto visual e a leitura não convencional são fundamentais para a autora. Como leitores, precisamos nos reorganizar para a recepção dos versos que cabem nas pupilas.

Uma outra explicação que ela nos oferece está em uma breve introdução ao livro Melómana (1979), que contém o poema estudado:

Mais do que nunca, preocupei-me com os fonemas. Por isso, ao ter consciência de que assinalam manchas visuais, tive de os fraccionar, o que me levou a alterações gráficas, de modo a que, entre a forma visual panorâmica, a forma sonora e a forma visual gráfica, houvesse correspondência.

O texto registra as palavras pensadas como som. Os poetas sempre sonharam que as palavras teriam a forma dos objectos.” (BRANDÃO, 2006, p.248).

Depois dessa breve exposição sobre aspectos formais da obra poética de Fiama, nos deteremos em uma possível leitura do poema. Notamos o adjetivo vivos para pormenores. Lembramos das Cenas Vivas, onde se discute e ressalta a questão sobre realidade e cotidiano presentes na poética de Fiama, questão central em sua poesia.

O cenário é a quinta, com sua horta e pomar, a estação é o outono, uma cena crepuscular, o que lembra o pessimismo das últimas décadas oitocentistas, como os poetas do título, numa versão generalista. $\mathrm{O}$ sujeito poético se pronuncia, depois de nos pintar a cena "viva", está em busca do matiz vago desses poetas. O $11^{\circ}$ verso separa a cena campestre do outro tema, a linguagem poética e os poetas.

A voz da enunciação refere-se a uma horta, ou seja, um elemento campestre, cotidiano, real, cita a realidade da escrita e relaciona a sua poética à de Mallarmé, 
justamente o poeta que se distancia das coisas do modo como são. Intercala o vocabulário relacionado à terra com questões poéticas; a cultura e a natureza (questão clássica); Mallarmé a "outrosversos que eu li em (Este) Rosto.” Ou seja, a versos dela mesma que passa a ser leitora e confirma a prática em sua poética da intertextualidade e da intratextualidade. A relação que se estabelece é emaranhada pela sugestão do movimento de passagem "pordentro", assim com os vocábulos grudados.

A imagem de enredado continua pelo poema inteiro até os últimos versos: "Estarnap-/oesia francesa e na quinta queé/ um reino de insectos permanentesob/cecantes emlinhasespirais". As oposições perpassam os versos: "anelídeos bolasde terraarenosa" às "hastes de trigo que parecem inquebráveis" - a relação se estabelece pela nitidez da luz, que também é a nitidez "dos fonemasrepletos de figuras" e a cor da terra. Entre o pensamento visual - "com a grandeza das tona-//lidades" e a forma da poética de Antero - "paraquem opensamen-/to visual era inferior." Os versos marcados por sons que vão se diluindo: "Diluem-se vários/ volumesnosváriossons como/ fileira depilares seiadiluin-do na borda das áleas".

A trama se coloca entre um cenário bucólico e a linguagem, contrapondo Mallarmé e ao mesmo tempo emaranhando-o, enquanto a cena está longe da linguagem dele, os versos de ambos se enredam.

A poesia de Fiama não se desenrola de maneira linear, o verso se abre e, por essa abertura, sobrepõem-se, soltam-se, afastam-se e juntam-se, em diferentes níveis de profundidade, outros movimentos de frases, outros ritmos de falas, que se relacionam uns com os outros, às vezes estranhas à lógica comum, lógica de subordinação, que uniformiza o movimento. Nesse sentido, de acordo com a leitura que Blanchot faz de Mallarmé, as poéticas se aproximam, há uma profundidade porque "supõe um espaço em várias dimensões, e só pode ser ouvido segundo essa profundidade espacial que precisamos apreender simultaneamente em diferentes níveis" ( BLANCHOT, 2005, p.347).

Em "O Triplo nome de Sophia" publicado em A Phala - um século de poesia, de 1988, Fiama cita o artigo de Sophia de Mello Breyner Andresen denominado Poesia e Realidade: 
A Poesia é a relação do homem com a Poesia. Ou melhor: a poesia é a relação pura do homem com as coisas. Isto é: uma relação com a realidade, tomando-a na sua pura existência. O poeta é aquele que vive com as coisas, que está atento ao real, que sabe que as coisas existem. (BRANDÃO, 1988, p. 82).

Fiama declarou, nesse artigo, que a poesia de Sophia tinha-lhe despertado as "janelas da alma", quando estava a dar seu "primeiro passo filosófico entre as coisas e o nome". Sophia surge para Fiama como intérprete da língua materna cotidiana e escolar porque, em sua poesia, atenta ao real, a matéria poética é o real imanente.

Rosa Maria Martelo escreveu sobre Fiama que:

Os "olhos hereditários", associados a uma "linguagem quotidiana de relação" devem, pois, em seu entender, ser resgatados do hábito, pela poesia, e forçados a re-ver a amplitude semântica de cada palavra, (...). Ora outra ideia essencial no mesmo poema ${ }^{21}$ é a de que as palavras "despem objectos", isto é, obrigam a vê-los na sua pura integridade. (MARTELO, 2004, p.177).

Se o poeta é aquele que vive com as coisas, ele sabe que existe uma inércia ao olhar o cotidiano, e o poeta amplia e resgata a palavra do olhar convencional sem desviar a visão. Fiama não nega a hereditariedade, nem a tradição - “existimos sobre o anterior" - mas suas palavras "despem objectos", ou seja, torna-os vivos.

Eduardo Lourenço, no prefácio de Obra Breve, escreveu: “O fantástico inerente à poesia de Fiama é, não o fantasmagórico e o irreal, de genealogia romântica, mas a polpa mesma da realidade, a mais visceral e epidérmica ao mesmo tempo, a carne de Deus feita matéria de que tudo é feito.” (LOURENÇO, 2006, p.11).

Portanto, o real, as cenas vivas, é a matéria da poética de Fiama. Quem está vendo as "cenas vivas" é alguém que tem passado, presente e futuro e estes estão presentes no

\footnotetext{
${ }^{21}$ Refere-se ao poema « Grafia 1 », comentado acima.
} 
poema, não como biografia, sentimentalismo ou confessionalismo, mas como "a mais visceral e epidérmica (a polpa da realidade) ao mesmo tempo." Ou, melhor: "não existe qualquer desequilíbrio ou tensão que dificulte a relação entre os nomes, as coisas e a voz, ou, se quisermos procurar outra formulação, que afaste, de um real visto em evidência, as mediações inerentes aos processos de conceptualização do mundo por parte do sujeito.” (MARTELO, 2004, p.179).

A questão do real permeia toda a obra de Fiama, se tornará central em Cenas Vivas e elaborada como uma arte poética em "Teoria da realidade - tratando-a por tu". Vamos ler um poema do livro (Este) Rosto (1970), livro no qual António Ramos Rosa detecta um novo discurso poético, relacionado à presença do real, portanto o princípio dessa realidade.

Pungente o verde
A luz ou realidade exerce o seu fascínio:
cinjo-me à linha que de coisas entre coisas parte ${ }^{22}$,
as conduz ao ponto corrosivo da imagem. Sinto-me
atenta, e vibra a minha face já defronte
da foz que da água o curso, doce,
salino liquefaz. Como
as mistura? Quanto dura impreciso
o seu contorno? Onde o corrompem
limos, fios visíveis?

Entre o declínio e a mancha de água,

\footnotetext{
${ }^{22}$ Fiama Hasse Pais Brandão usou os dois primeiros versos como epígrafe do livro Cantos do Canto (1995).
} 
pungente o verde tinge a curva

de rocha ou ponta térrea emersa.

O simples dom de ver que o olhar emite ou colhe:

a parte entre uma orla e as margens recolhidas.

Ténue, com a cor, é mais visível

a imagem da água corrente que decide

o meu olhar que vê e o mar que cede

à rocha ou à imagem que o percorrem.

Cria-se o fio que junta ao que se vê, intérmino,

a luz acesa em si, na superfície; as formas

em que retêm as ondas

vívidas a pupila

que no acto excede o seu volume

e é algo que à tona de água vem verter a imagem

na sua origem turva, definida.

O verde amplia

o fim que é dado à vaga. A crista

de linhas convertidas em figuras,

em conflitos de nexo e de desenho

que toda a ave traça

- saída do seu tempo sobrevoa

a costa, nome dito.

Assim repousa, vendo, quem nomeia

essa mudança do inverno para o tempo

primeiro da estação aonde o mar começa, sendo imagem.

A rocha escava, o leito espraia a areia, 
a flora ondula. Agora o olhar progride sobre tudo

e a pua, rente ao solo, de um rochedo

isola-se; que dor, a de rasgar

a berma de água unida, a primavera ser

o tempo, a pedra exígua no limite

da água furtar na sua renda a harmonia?

Quem entretece, logo, à luz? Por que soa

o tempo a quem vive tão pungente,

tanto como o verde dissonante?

(2006, p. 91 - 92) .

O título nos remete a duas questões: à presença da realidade circundante e como ela afeta ou impressiona o sujeito poético através do adjetivo pungente. A imagem inicial é de um sujeito poético que se mistura e se envolve "à linha que de coisas entre coisas parte" e vai se transformando num elo entre a realidade e o poema. É o momento de contato com a palavra através da imagem. O foco é o sujeito poético; através de seu olhar vemos uma cena que se constrói e se desconstrói. O movimento é duplo, tanto do olhar que "emite ou colhe", quanto da imagem da água "que decide o meu olhar que vê e o mar que cede"; a infinitude e as formas que retêm as ondas; a amplitude e o que excede e a imagem que se forma e se transforma em figuras, "igualdade entre uma palavra e uma imagem" (BRANDÃO, 2006, p.293). O sujeito poético é aquele que nomeia não o real, mas a imagem, é atento e as imagens se ampliam e se transformam. Há uma dor, a de estar atento e perceber o tempo e o movimento do real.

O verde é pungente no título e nas primeiras estrofes; o verde amplia, na quarta e na última estrofes. Nesta, pungente se torna característica do sujeito poético, mesmo que já na primeira vez que "pungente" aparece é uma projeção do sujeito, mas na última há uma metamorfose, o sujeito "vive tão pungente", se iguala ao verde. Saímos da realidade do poema com uma percepção da realidade empírica. 
Neste sentido, podemos aproximar o poema de William Carlos Williams, que se relaciona com alguns questionamentos de Fiama:

\section{The Wind Increases}

$$
[\ldots]
$$

Good Christ what is

a poet if any

$$
\text { exists? }
$$

a man

whose words will

$$
\text { bite }
$$$$
\text { their way }
$$

home - being actual

having the form

$$
\text { of motion }[\ldots]^{23}
$$

Como já mencionamos, em um depoimento manuscrito, Fiama escreveu que "eu, quando li e quando leio um Poeta, vou absorvendo sempre sua teoria do real, e sua expressividade e os seus sentimentos". Assim como a autora ao ler percorre a trilha deixada pelos poetas da sua teoria do real, da sua expressividade e de seus sentimentos, entendemos que a teoria do real é um dos fundamentos da poética de Fiama. O primeiro material que trabalhará é o real, a realidade, resta-nos saber a que realidade ela está se referindo.

\footnotetext{
${ }^{23} \mathrm{O}$ vento aumenta
}

[...] Deus meu o que é/ um poeta se é que algum/ existe?/ /Um homem/ cujas palavras/ vão abrir/ caminho/ para casa - sendo reais// tendo a forma/ do movimento [...] - tradução de José Paulo Paes, in W.C.Williams. Poemas. São Paulo: Companhis das Letras, 1987. 
A instância do poema se torna ou é a realidade. Ela consubstancia os dados empíricos com os dados do artefato poético, da realidade poética. Não separa a realidade do poema da realidade empírica, nem enaltece a poesia.

Fiama dá continuidade ao seu primeiro verso, expande sua obra sempre com o olhar na realidade empírica e a torna realidade do poema. Rompe com prévias expectativas, modificando e inaugurando a nossa percepção e o nosso entendimento do real e do poema. 


\title{
Capítulo 3
}

\section{"Teoria da Realidade - tratando-a por tu" - uma arte poética}

\begin{abstract}
Versos não são o que as pessoas imaginam, simples sentimentos (a esses, temos cedo demais) - são experiências. Para a construção de um simples verso, é preciso ver muitas cidades, homens e coisas, é preciso conhecer os animais, é preciso perceber como os pássaros voam e conhecer o movimento que uma flor abre pela manhã. (...) E também não basta ter recordações. É preciso saber esquecê-las, quando são muitas, e ter a grande paciência de esperar que retornem por si. Pois as lembranças em si ainda não o são. Só quando se tornarem sangue em nós, olhar e gesto, sem nome, não mais distinguíveis de nós mesmos, só então pode acontecer que numa hora muito rara se erga do meio delas a primeira palavra de um poema.
\end{abstract}

Os cadernos de Malte Laurids Brigge de Rainer Maria Rilke

A poesia já não se impõe, expõe-se

Paul Celan

E a terceira voz? Existe realmente? Eco simultâneo das outras, sopra como o vento, parte as frases em palavras, as palavras em sílabas, as sílabas em gritos (fragmentos de sons). No entanto, o segredo da conversa não se estilhaça. Pelo contrário. Este processo misterioso desvenda-o sem lhe tocar: afasta ou rasga um véu (depende da intensidade) e o equívoco ( a sua imagem) surge compreensível.

Finisterra de Carlos de Oliveira

as mãos derrubam arestas

a palavra principia

Fiama Hasse Pais Brandão 


\section{O Poema}

\section{Teoria da Realidade - tratando-a por tu}

Ouves cantar a flosa, e erras,

não é ela, era o mar antes criado,

era a galáxia, o teu cérebro, aquela

que já ouviste ao aprenderes a fala.

Esta ao menos tiveste de a ouvir,

a do primeiro nome, no regaço

da tua mãe equívoca, mulher

e voz, mulher e luz, seio,

rumor, adejo. Se ouviste cantar

a flosa contra o fundo murmúrio

do mar, foi porque também depois

o bebeste na matriz da carne

ou na dos astros - a tua mãe de berço,

a Natureza - no seio falador, no mamilo

astral, das palavras mar, murmúrio.

tão roucas como a palavra flosa,

as do primeiro dia da tua fala,

dia a dia, quando antes vagias

tal como as tuas mães, no berço,

antes do seio, antes do grande Cosmos.

Ainda estás muda, mas ouves

cantar um nome, ouviste já

dois nomes, tu queres dizê-los,

tacteias, sugas, redizes. 
A primeira palavra já a dizes,

encastoada na substância do mar,

agora que puseram o mar todo

a teus pés, e ao dizer-te a palavra,

alguém a poisou e ao mar

debaixo dos meus passos. Alguém

é outra voz, além das vozes

ocultas, maternais, de outrora.

Alguém não é um eco, é a terceira

fala, mensageiro sem início,

apenas boca presente, junta,

que veio nascer contigo. Nunca

teu gémeo, ou duplo, apenas de um lugar,

ali, alguém no espaço, contigo, a ouvir.

Flosa, o teu canto é confuso

como o de minha mãe.

40

E, já uma vez, num verso, eu te pus

a cantares-te a ti mesma, mas agora

é a mim que me falo. Este é

o mar, a fala de quem chamar,

a meu lado, o mar. Terceiro nome

que tem a força para separar,

de um lugar de mães, o espaço lateral

de outro, de outrem, o tacto do mar,

trocado pela tua mão que tacteia.

Cantas, ouvido das palavras, tacto,

flosa, pássaro cantante, depois

de teres sido o primeiro pássaro. 
E tu, terceira fala, também

estranha, equívoca, quando tornas

a tua fala um som. Perto do mar

a tua boca toca-lhe e toca-me.

Três são as palavras comigo -

a flosa, o mar, e tu. Estou

ou sou debaixo do fascínio

deste tríplice tudo. (Agora

tenho em mim o tempo instilado

pela fala mútua e pelo ouvido.)

E com as três palavras posso

ouvir essa poderosa voz,

que era, além, um poeta,

depois de, como eu, ter bebido

o leite da palavra. Foi o mar.

Foi o mar, ó mar salgado,

e quantas das águas serão

as lágrimas de Portugal. Agora

tens de saber o que podemos ser:

águas, lágrimas, o Portugal.

Tens de tactear os meus olhos

com o toque do mar. Era criança,

e de súbito o mar foi o sinal

da palavra nova, o ser da água

ou das águas, similares

no $a$ vivo, a mais audível

nascente do alfabeto, o eco. 
E os meus olhos mostraram também

ao mar as lágrimas com o $a$ de sal.

E o inteiro ouvido engendrou

a máxima palavra Portugal,

tu, realidade, meu poeta.

Meu poeta, quem? Aquele que fala

com as assonâncias, analogias,

o uníssono e o tacto, os nomes

naturais matrizes guardadas

por sua mãe. O eu mais rápido,

criança que saiu do próprio berço

90

e se torna, ela mesma, elemento, pela fala,

ao ouvir palavras, das três

palavras minhas. Tão de repente,

realidade, tu poisaste o teu pé

nas pegadas do mar, disseste

águas, exorbitaste dos olhos,

95

e repetiste: lágrimas. Chamaste

a coroa das palavras, neste lugar:

a língua, no tempo de Portugal.

$\mathrm{Tu}$, realidade, és nome de ti

e do que os poetas fundam,

100

depois de terem a fala perfeita.

Tens na inspiração do ar o $a$ total

que une em si a boca dos poetas

tal como, em mim, o Camões ao de Estugarda.

Este fundou a fala já falada, 
o canto refeito, que é legado.

Aquele leu o já lido, dobrou

o antigo canto clássico. Mas,

ó minha palavra muda, pensada,

detém-te. Já falas nos poetas,

porém, em ti, só tens o ar,

além das tuas três palavras. Depois

da voz cansada, inspira o mar, repara

nas marcas da água. Narravas.

Quando tu me tocaste, no mar,

assinalavas as tuas marcas,

as palavras: águas, ó águas!

Depois das três palavras, deixaste-

-me falar comigo, e eu, cansada,

palavra após palavra, ouvi um poeta,

mais dado à realidade,

a ti, ó realidade! Este era, em si,

sem nunca saber do de Estugarda.

E dele, por ele, refundei a língua

em que Portugal me falava: mãe

tão longe já da minha fala,

mãe mutilada, porque a fala-língua

já não é clara, e aquelas palavras,

as três de toda a realidade,

agora são as estrofes dos meus versos.

Minha realidade, tu não sabes

como o Camões, nos seus dez cantos,

te deixou presa entre dois tempos. 
Ouviste a flosa ser cantada,

a cantar-se. Agora estás rodeada

desta língua que nasceu do $a$.

Inspiras, expiras. Os versos

só são o que os poetas fundam.

Flosa, mãe, mar, em que versos

somente sois as palavras minhas?

140

Tu deste-me as palavras novas

da tua fala escassa, calada

pelo escorrer do leite. Depois,

a língua mudou-te as dimensões,

e cada verso é uma linha tua,

em que eu te fundo. O que sou,

ao chegar a um limite da fala,

a um verso, que os poetas fundam?

Mas deixo o abstracto, a galáxia,

o cérebro e até um verso. Estou

no simples lugar do mar, velha água,

muralha a bordejar-te.

Pelo plano do mar correm crianças,

como eu, na sua fala, e os barcos

estão a ser chamados por um nome.

Toda a longa costa continua

Portugal, em lágrimas de sal.

Vai alto o sol, renova-se

o real pelos meus olhos, fitos

na Graça do mar, que é derramada

160 
sobre esta língua e os versos.

Balbuciando, assim os poetas nascem

das mulheres-braços, que os lançam

no concreto, no lúdico mar.

Que, em jogos, seguem as pegadas

de outros, que as seguem de outros,

já tu sabes. É a terceira voz,

que te revelo agora ser a voz

de poetas, seguida marca a marca.

Juncaste a praia do $a$ das palavras

170

portuguesas, tu que conheces já

o primeiro som da vida.

O sol brilha, nos telhados do mar,

ó meu coveiro, e uma criança,

na cova que cavou, vazou o mar.

Não eu, mas outra criança-mundo

a começar. Os baldes da infância,

as bolas, os arcos, são jogos

de palavras. Mas aqui, no chão da praia,

se eu disser a minha língua solitária,

crianças abandonam o seu riso,

crianças duvidam do jogar.

Calo-me, e toda a praia está

entre tempo e lugar, solar,

vital, grega, pujante. Vem,

e os banhos teus, realidade!

Também aqui estarás, se eu me calar, 
a ver mãos moldarem o mar,

ou se algum poeta loquaz se calou

desde a idade clássica. Mas tu erras,

temente não queres sair jamais

fora da minha boca, e se aceitas

a dos clássicos, apagas-lhes as marcas.

Realidade, tu tens o teu princípio,

estendes-te, avolumas, estás,

mas não recuas, nem que os poetas

te chamem à sua língua antiga.

Sim, os clássicos chamaram-te, e eu

li que antes da voz dos clássicos,

a Via Láctea, ninho de galáxias,

o Cosmos, o Caos, estiveram mudos.

Falaram-te os poetas gregos, poetas lidos.

Ler faz embater a fala nas palavras

que são ouvidas no ouvido.

Ouves palavra-eco que vêm

para mim de novo, se essas

crianças repetirem crianças.

Elas levam o balde cheio de água

para encher a maré, levantam

a barbacã de areia, seguindo o plano

dado pela voz de alguém do meu início

ou de um livro de páginas abertas

rente ao mar. Por vezes, tu,

realidade, és um livro, aberto

numa página com o mar. 
E a pura mãe folheia-te?

Falemos mais dos gregos, que amaram o mar com a boca

do canto dos aedos e da escrita,

e com os barcos, que apontavam

pelas linhas dos códices, na singradura.

Ó realidade homérica, tu és

pelos tempos traída, pelas línguas,

e eu, que medeei da fala para a leitura,

eu leio as epopeias para ti.

Se fosse tu, digo-te, a primeira

após a fala, e a palavra de poeta

seguida pelos poetas, seguidora

de todos, quero louvar-te a ti. Sabes

o que é canto, tu? A medida contada?

A harmonia flui do meu ouvido,

o falado pela ordem das sílabas,

as pausas, vogais entoadas. Som,

palavra dada, do abstracto ao tacto

do meu ouvido. Manhã, infância

em que a mãe de luz embala

as palavras no canto. Afinal,

mãe tripla, a do leite, a da fala,

a do número. Eu, depois desses poetas,

sei, tu não, que recupero

a perda da nascente da tua água,

a mina da voz, soterrada.

Calada mãe, geraste tudo o que é 
ambíguo. Este falar, ouvir, ler, cantar,

tu não no-los deste, sou eu

o artífice deste mar espraiado,

da praia que contorna Portugal.

Canto o coral do $a$, o som ritual.

O mar global é como o ar,

dá-se a ver na amplidão.

Dela recebe a fala com a voz,

as palavras, altas, irreais.

Mas não me oiças negar-te,

realidade do mar, palavra minha.

Criança, a tua mão de areia

construiu a praia. Os teus dedos

sonoros chamam-me agora.

Chamei-te, outrora, eu, no transe

do som a pousar no meu mar.

Aceita a água que vem

para os teus pés, recebe a luz, colhe

as pequenas algas. São-te dadas

pelo passado tempo, ainda

recordado, em ti, por mim, realidade. 


\section{Uma leitura de "Teoria da Realidade - tratando-a por tu"}

O poema, “Teoria da Realidade, tratando-a por tu”, está no livro Cenas Vivas, na terceira parte, denominada Poéticas. Há seis poemas longos em Poéticas, cuja característica predominante tende a uma reflexão sobre o fazer poético. Portanto, podemos concluir que esse poema é uma arte poética, é uma das artes poéticas.

O título do poema propõe-se a um diálogo. A autora enuncia a realidade e a trata por tu. Ela, como poeta, quer ser íntima da realidade e quer estabelecer um diálogo. Ou, se pensarmos que é uma arte poética, a poesia, para Fiama, precisa desse diálogo para acontecer. O tu é bastante emblemático porque tem valor com um grau de intimidade significativo.

Na filosofia grega, teoria é o conhecimento de caráter estritamente especulativo, desinteressado e abstrato, voltado para a contemplação da realidade, em oposição à prática e a qualquer saber técnico ou aplicado. Por outro lado, real é o que constitui o mundo do sujeito.

O sujeito poético vai ao encontro da realidade empírica, vai às origens. Trata a realidade por $\mathrm{tu}^{24}$, em outras palavras, a realidade é próxima, é íntima, é o lugar onde existimos - desde os inícios -, escreve sobre os próprios inícios: humana, natural, cósmica e literária.

O subtítulo, "tratando-a por tu", supõe um relacionamento íntimo, no encontro com a realidade, o reino do relacionamento é um reino em que predomina a relação. Ao contrário do isolamento, onde não é possível haver relacionamento.

Nesse sentido podemos mencionar Martin Buber, o filósofo que tanta atenção deu ao "tu”. Recupero palavras de Buber citado por Thomas Ransom Giles (1989, p. 217): "É no encontro com o $T u$ eterno que descobrimos a fonte dos movimentos históricos do homem em direção a novas decisões, a novas estruturas, a toda ação humana, a todos impulsos criativos à procura da forma." ${ }^{25}$ Assim como para Buber,

\footnotetext{
${ }^{24} \mathrm{O}$ tratamento por tu revela intimidade principalmente em Portugal.

${ }^{25}$ Palavras de Giles sobre o Tu eterno e sobre o pensamento de Buber: "O acontecimento relacional não é tanto um passo extraordinário quanto a realização daquilo que já estava envolvido no encontro
} 
para Fiama, o diálogo é uma abertura ao outro, faz parte do relacionamento, é natural. No poema estudado, o tu, no primeiro momento, é a realidade.

Assim, é um poema que começa com uma voz que dialoga com um tu. O tu, assim como o sujeito poético, integra a realidade. "Tratando-a por tu", o poeta conhece muito bem a realidade e com ela tem intimidade.

Escutemos a voz do poeta Paul Celan (1920-1970), que escreveu sobre a arte poética e, em seus poemas, se refere a um tu, tanto que Hans-Georg Gadamer intitulou um trabalho crítico sobre a obra de Celan de Quem sou eu, quem és tu?

O poema, sendo como é uma forma de manifestação da linguagem e, por conseguinte, na sua essência dialógico, pode ser uma mensagem na garrafa, lançada ao mar na convicção - decerto nem sempre muito esperançada - de um dia dar a alguma praia, talvez a uma praia do coração. Também nesse sentido os poemas estão a caminho têm um rumo.

Para onde? Em direcção a algo de aberto, de ocupável, talvez a um tu apostrofável, a uma realidade apostrofável. Penso que, para o poema, o que conta são essas realidades. E acredito ainda que raciocínios como este acompanham, não só os meus próprios esforços, mas também os de outros poetas da geração mais nova. São os esforços de quem sobrevoado por estrelas que são obra humana, de quem, sem tecto, também neste sentido até agora nem sonhado e por isso desprotegido da forma mais inquietante, vai ao encontro da língua com a sua existência, ferido de realidade e em busca de realidade. (CELAN, 1996a, p. 34).

Sou tu quando sou eu (CELAN, 1996b, p. 13).

A questão da alteridade, do sujeito, do tu, é uma questão sobre a qual a modernidade se debruçou. Podemos nos lembrar de Rimbaud quando afirma "Je est un dizer, justaposta à esfera atual do relacionamento.." (1989, p.216). 
autre". Octavio Paz (1914-1998) escreveu em "Piedra de sol", um poema longo de 1957: "adonde yo soy tu somos nosotros". ( PAZ, 1997, p.232).

Ao longo do poema agora em questão, o tu pode variar de referentes.

“Teoria da Realidade, tratando-a por tu” é um poema longo, com 15 estrofes irregulares e 266 versos livres. Causa estranhamento os pontos finais no meio de versos e o uso de um tipo de enjambement que corta o sentido daquilo que é ordinariamente considerado unidade de significado. Não há uma expectativa que seja criada por um padrão rítmico, como também não há uma preocupação explícita em quebrar o ritmo. $\mathrm{O}$ poema segue seu curso sem sobressaltos aparentes, sem ressaltar as irregularidades métricas nem construir uma regularidade própria ou tradicional. Enfim, a disposição no papel é discreta.

As assonâncias e aliterações se expandem de forma variada pelo poema. O resultante é mais ou menos regular, tendendo para o coloquial.

Os temas se alinham e edificam cumulativamente, gerando um sentido que se aprofunda ao longo da leitura. Os versos se expandem abrangendo mais significados. A imagem da flosa ${ }^{26}$ plana pelas primeiras estrofes, até a nona, verso 141. Por isso, dividimos o poema em duas partes. A nona estrofe retoma algum léxico da primeira, criando uma intratextualidade no mesmo poema, resolvendo uma problemática e apontando para outra.

A primeira parte é ligada ao passado, ao distante, ao abstrato, segundo o sujeito poético, e a segunda parte é ligada ao presente, ao concreto. Na primeira parte, há preocupação de explicar toda a história e as influências poéticas da autora; na segunda, o sujeito poético se encontra "no simples lugar do mar", deixa o abstrato.

Sabemos que na Modernidade não há obras em que a relação entre o particular e o geral seja de unidade imediata. As partes podem manter graus diferentes de independência em relação ao todo, já que o conceito de obra se ampliou. O leitor tem nelas papel ativo, procurando ele mesmo trilhas de ligação. “Parce que l'enjeu du

\footnotetext{
${ }^{26}$ Flosa é um pássaro migratório, que constrói o ninho com fios que tece com o bico. É também conhecido como papa-amoras, papa-figos, tuti-negra, felosa, folosa, chiadeira. É um dos mais comuns invernantes em Portugal e se distingue por seu canto.
} 
travail littéraire (de la littérature comme travail), c'est de faire du lecteur, non plus un consommateur, mais un producteur du texte." (BARTHES, 1970, p.10).

O sujeito poético conta como essa voz poética se gerou e gestou dentro dele, conceitua a "fala perfeita", não como ideal de perfeição, mas como depuração de sua voz, genuína, original, digerida a partir de memórias existenciais e literárias. No diálogo instaurado nas primeiras estrofes, através de um interlocutor que ouve o canto da flosa, o sujeito poético nos transporta para a questão da temporalidade, ou seja, aquele momento não é o presente apenas, mas o presente saturado de memória, portanto de passado. Leva-nos a pensar sobre a realidade, termo que faz parte do título. O termo "fala perfeita" só aparecerá na 6 . estrofe, vinculado à realidade. Para pensar sobre a "fala perfeita", a Autora nos coloca outro problema, o da temporalidade e ambos estão relacionados à realidade, ela está ou é desde que a pronunciamos, como veremos ao longo da análise.

Até a sétima estrofe, o último verso "Narravas", a autora conta uma história, a da experiência de sua voz poética, que é também a descoberta da palavra poética. O tom muda, mas não completamente de modo que poderíamos dividi-lo em outra parte, mas essa ruptura só acontecerá no final da nona estrofe, o que justifica, em nossa leitura, a divisão, a partir da décima estrofe.

Na tese, realizaremos uma análise do poema estrofe por estrofe, já que o poema é longo e complexo, mas antes de passar a esse modo de análise, discorreremos acerca de três imagens fundamentais que o percorrem: a flosa; o mar; e a alteridade ou o tu, sobre o qual expusemos um pouco acima e, ao longo da análise, aprofundaremos essa questão.

A primeira imagem com que nos defrontamos é a da flosa, palavra desconhecida em dicionários brasileiros; mesmo em Portugal, ela não é cotidiana e é desconhecida por muitas pessoas cultas, como pudemos averiguar. Entretanto, por meio de leituras, ou seja, a partir da leitura do poema estudado, descobrimos a pluralidade de significados que a poeta insufla ao significado original, além de dar-nos conta de que o significante lembra o nome da poeta: Fiama. A definição está em nota de rodapé anterior. Ficamos com a definição de pássaro migratório, um dos mais comuns invernantes em Portugal, se distingue pelo seu canto. Essa ave sobrevoa toda a primeira parte do poema, como mostraremos nas citações a seguir: 
Ouves cantar a flosa e erras,/ não é ela, era o mar antes criado,/ era a galáxia, o teu cérebro, aquela que já ouviste ao aprenderes a fala. (verso 1).

... Se ouviste cantar/ a flosa contra o fundo murmúrio/ do mar, foi porque também depois/ o bebeste na matriz da carne/ ou na dos astros - a tua mãe de berço,/ a Natureza no seio falador, no mamilo/ astral, das palavras mar, murmúrio. (verso 10$)^{27}$.

Tão roucas como a palavra flosa,/ as do primeiro dia da tua fala,/ dia a dia, quando antes vagias/ tal como as tuas mães, no berço,/ antes do seio, antes do grande Cosmos."(verso 16).

Flosa, o teu canto é confuso/ como o de minha mãe./ E já uma vez, num verso, eu te pus a cantares-te a ti mesma, mas agora/ é a mim que me falo. (verso 39).

Cantas, ouvido das palavras, tacto,/ flosa, pássaro cantante, depois/ de teres sido o primeiro pássaro. (verso 51).

Três são as palavras comigo -/ a flosa, o mar, e tu. Estou/ ou sou debaixo do fascínio/ deste tríplice tudo. (verso 58).

Ouviste a flosa ser cantada,/ a cantar-se. Agora estás rodeada/ desta língua que nasceu do $a . /$ Inspiras, expiras. Os versos/ só são o que os poetas fundam. (verso 136).

Flosa, mãe, mar, em que versos/ somente sois as palavras minhas? (verso 141).

Estes são todos os versos em que aparece flosa em "Teoria da Realidade, tratando-a por tu”. No primeiro e no décimo versos, a poeta apresenta o canto da flosa, tendo como destinatário o tu. No $16^{\circ}$ verso, flosa está em itálico, a autora chama nossa atenção para o vocábulo e para o som, rouco, como as primeiras palavras pronunciadas por um tu, talvez a própria voz poética. (Aparecem em itálico as palavras mar e murmúrio, verso 10. Assim a poeta destaca a palavra e a sonoridade, leva-nos ao significante, além do significado).

\footnotetext{
27 Os negritos são meus, os itálicos são da autora.
} 
No $39^{\circ}$ verso, compara o canto da flosa ao da sua mãe, ambos confusos, o interlocutor é a flosa. No verso $51^{\circ}$, define quem é a flosa: "pássaro cantante, depois/ de teres sido o primeiro pássaro". No verso $58^{\circ}$, flosa é uma das três palavras que o sujeito poético possui. No verso 136, a flosa canta a si mesma, numa intratextualidade. Percebemos que flosa, pode significar a poeta, assim como pássaros já foram sinônimos de poeta, ou da voz poética, aquele que canta. E, no verso 141, refere-se à palavra flosa como integrante de seu processo de aquisição da linguagem poética, adiciona-a à mãe e ao mar. Flosa vai adquirindo significados ao longo do poema. A poeta retoma cada um e aprofunda, até ser uma das três palavra que lhe pertencem. Fiama expande os vocábulos, tanto em relação aos significados quanto em relação aos significantes.

Pensando no significado de flosa, surgiram questões: a flosa é um pássaro, portanto "canta", assim como o poeta; é um pássaro itinerante, migrante, que está em Portugal no inverno, o que nos remete a mudanças, metamorfoses, transformações, temas recorrentes em sua poética. A autora nos acena com uma peregrinação ou voo. Há duas direções, em seu poema, para cima, para o ar, através da imagem do pássaro e para dentro, ou profundezas, porque vai esmiuçando as palavras, ideias e sentimentos, introjetando-os.

Estendendo o significado de flosa para a espécie, constatamos que, na obra de Fiama, há tipos de pássaros ou aves em poemas, espalhados por sua obra toda, desde os primeiros poemas, que não foram publicados em Obra Breve. Em 1956, por exemplo: "a meditar na ondulação dos pássaros/ que desenham em si o arco/ para atravessar."; em 1958: "a límpida/ rítmica/ gaivota,/ fluida/ na harmonia do vento-mar.// Penetra-me/ um símbolo de infância"; e "No fundo da alma/ só asas fendidas." 28 Em 1961: “Água significa ave/ se/ a sílaba é uma pedra álgida/ sobre o equilíbrio dos olhos". Em "Pássaros na varanda em Londres" (1989): "As aves, como tudo o que muda,/ vêm, afastam-se, transformam-se/ uma na outra. Uma forma contígua,/ em vez de uma forma alheia,/ faz cada ave mudar." (2006, p. 477). Em Sob o olhar de Medeia: "ave que seria sempre símbolo da alma ou vida espiritual." (1999, p. 38). Em, "Canto dos insectos"

\footnotetext{
${ }^{28}$ Retirados do Espólio nessa ordem. Em 1958, Fiama Hasse Pais Brandão não tinha publicado nenhum livro de poesia. Tivemos acesso a uns poucos poemas impressos por ela, os quais nomeou Espólio; saíram como separata da Revista "Ocidente" em 1989.
} 
(1995), escreveu: “As aves são as almas regressadas/ ou que vêm da matéria para nós.” (...) Cada voo entre o poente e o futuro/ está imóvel como nós no Tempo.” (2006, p. 555). Em Cenas Vivas (2000): "Outras andorinhas voltam, não as que/ partiram dos beirais, no Outono./ Mudaram no deserto as suas imagens,/ e as que volteiam hoje sobre esta água/ no passado conheceram outro destino./ Que lugar trarão na memória dos olhos? (2006, p. 614). ${ }^{29}$

As imagens de pássaros sugerem desenhos que se esboçam no ar. Relacionamos a memórias infantis, a perdas (porque estão sempre indo e vindo), a metamorfoses, a mudanças espaciais; estão relacionados também à forma em poesia, instáveis, esvoaçando de lá para cá; simbolizam a vida espiritual, a leveza, a liberação do peso terrestre, de acordo com dicionários de símbolos. Fiama escreveu que "são almas regressadas"; ainda, podemos estabelecer ligações com o tempo, porque são sazonais. Todas essas referências estão em sua poética, então, quando escreve flosa, relacionamos a esse universo.

Pássaros, ave, depois, gaivotas, andorinhas, melro, corvo, cisne etc., cada pássaro traz consigo uma história de aproximações com certos autores que percorrem a história literária. Por exemplo, quando o corvo aparece em um poema, é frequente que o relacionemos ao universo literário de Edgar Allan Poe; o rouxinol a Keats; o cisne a Baudelaire; o azulão a Manuel Bandeira, as andorinhas a Fernando Pessoa, Manuel Bandeira e à própria Fiama Hasse Pais Brandão.

Se retomarmos o verso inaugural da Autora: “Água significa ave” e pensarmos que flosa é uma ave, um terceiro pássaro; constatamos que é uma metáfora em processo de deslocamento. Ainda, retomando o segundo capítulo, e a questão da "fala perfeita", pensamos que perfeito porque está sempre per fazendo, perfeito, em se fazendo perfeitamente.

A imagem mais presente nesse poema é a do mar. Se, a flosa aparece na primeira parte do poema, o mar aparece, com exceção da sétima estrofe, em todas as outras: "o mar antes criado" (verso 2); "Se ouviste cantar/ a flosa contra o fundo

\footnotetext{
${ }^{29} 2006$ é a data da publicação de Obra Breve, poesia reunida de Fiama Hasse Pais Brandão. As datas depois dos poemas é a data da publicação de cada um.
} 
murmúrio/ do mar" (versos 9-10-11); “das palavras mar, murmúrio.” (verso 15); "encastoada na substância do mar,/ agora que puseram o mar todo/ a teus pés"(versos 26-27); "alguém a poisou e ao mar/ debaixo dos meus passos" (versos 29-30); "Este é/ o mar, a fala de quem chamar,/ a meu lado, o mar." (versos 44-45-46); "o tacto do mar" (verso 48); "Perto do mar/ a tua boca toca-lhe e toca-me." (versos 55-56).

Fiama conclui: "Três são as palavras comigo -/ a flosa, o mar, e tu." (versos 57-58). Depois continua: "Foi o mar" (verso 67); "Foi o mar, ó mar salgado" (verso 68); "e de súbito o mar foi o sinal/ da palavra nova" (versos 75-76); "E os meus olhos mostraram também/ ao mar as lágrimas com o $a$ de sal." (versos 80-81); "tu poisaste o teu pé/ nas pegadas do mar" (versos 93-94); "Depois/ da voz cansada, inspira o mar, repara/ nas marcas da água." (versos 112-113-114); "Quando tu me tocaste, no mar,/ assinalavas as tuas marcas," (versos 115-116); "Flosa, mãe, mar, em que versos/ somente sois as palavras minhas?" (versos 139-140); "Estou/ no simples lugar do mar, velha água,/ muralha a bordejar-te." (150-151-152); "Pelo plano do mar correm crianças," (verso 153); "na Graça do mar, que é derramada/ sobre esta língua e os versos." (versos 160-161); “que os lançam/ no concreto, no lúdico mar.”(versos 163164); "O sol brilha, nos telhados do mar," (verso 173); "na cova que cavou, vazou o mar." (verso 175); “ a ver mãos moldarem o mar," (verso 188); “ou de um livro de páginas abertas/ rente ao mar. Por vezes, tu,/ realidade, és um livro, aberto numa página com o mar." (versos 212-213-214-215); "que amaram o mar com a boca/ do canto dos aedos e da escrita,"(versos 218-219); “sou eu/ o artífice deste mar espraiado,"(verso 246); “o mar global é como o ar,/ dá-se a ver na amplidão.”(versos 248-249); “Mas não me oiças negar-te,/ realidade do mar, palavra minha."(versos 253-254); “Chamei-te, outrora, eu, no transe/ do som a pousar no meu mar." (versos 258-259).

O mar é como a coluna vertebral semântica desse poema. É um vocábulo que se quebra e recria, por exemplo, no verso: “o mar global é como o ar,/ dá-se a ver na amplidão”. Na palavra mar cabe o ar, ou seja, na palavra mar está contida a palavra ar.

Outra associação, que a poeta faz, é a da palavra mar com a palavra sal, e por consequência lágrimas e lágrimas de Portugal, ou seja, aqui não se limita apenas à palavra, mas também à substância mar, que tem sal, como as lágrimas. E, por associação, somos levados à história de Portugal, fortemente ligada ao mar e às lágrimas 
dos que vão e dos que ficam, das viúvas, na época dos descobrimentos, ou durante o colonialismo e as guerras em África.

Como metalinguagem em, por exemplo, "Chamei-te, outrora, eu, no transe/ do som a pousar no meu mar." É uma das três primeiras palavras da poeta. Está relacionada à história de Portugal e à literatura portuguesa; aos poetas que ela se refere neste poema: Homero, Camões, Hölderlin, Pessoa; à viagem, deslocamentos, limite de mundos. É quase um mantra, é um signo linguístico e poético. Podemos ouvi-lo e prestar atenção apenas à sonoridade, por outro lado, a semântica de mar é riquíssima, ainda se acrescentarmos que ao ouvir o mar, não é apenas ele que ouvimos, "era antes...". O mar comparece com toda sua complexidade.

Como escreveu Haroldo de Campos, em Galáxias (2004): “esse mar esse mar esse martexto por quem os signos dobram marujando num estuário de papel múrmurrúmor-remurmunhante escribalbuciando você converte estes signos-sinos num dobre numa dobra de finados enfim nada de papel estes signos você os ergue contra tuas ruínas...".

"Este é o mar", lugar de excelência na literatura portuguesa. "Dialogo com o mar, que sempre soa/ para quem carnalmente habita a costa" (2006, p. 566); "e termino o poema com o mesmo/ fogo interior sorvido pela boca/ do verso inicial no pleno mar." (2006, p. 569). Fiama cita os versos de Sophia Breyner Andresen (1995, p. 164), que foram lidos por ela, ainda criança, impactaram-na, e lhe chamaram atenção para a palavra poética ${ }^{30}$ : "E julgo, por fim, ter percebido: desde o primeiro verso sublinhado: 'arranco o mar do mar e ponho-o em mim', afinal, espantosa e magnificamente, até hoje, até Livro Sexto, por exemplo, a grande tentativa é uma demanda una, a da vida poética da autora.” (BRANDÃO, 1988, p. 82). Podemos comparar as palavras de Sophia citadas por Fiama à própria poética de Fiama, apontamos para a intertextualidade com a voz poética de Sophia, diríamos mais do que intertextualidade, chamaremos de influência.

Além das três imagens fundadoras do poema - a flosa, o mar e tu, da qual exploraremos mais oportunamente - apontaremos para outro aspecto importante, o tato.

\footnotetext{
${ }^{30} \mathrm{Em}$ artigo que comentaremos posteriormente.
} 
Em toda poética de Fiama há uma profusão de sensações, principalmente em relação à visão e à audição, também presentes nesse poema, em grau menor, mas é o tato o sentido privilegiado.

O tato está relacionado ao toque, é o sentido que utiliza o corpo, é concreto, como todos os sentidos, talvez o mais concreto. O que o diferencia dos outros sentidos é a aproximação que é preciso ter para existir a sensação, portanto está relacionado à proximidade física, o que traz concretude ao poema.

Se, a proposta da autora é tratar a realidade por tu, ou seja, ser e estar próxima a ela, nada mais percuciente do que privilegiar esse sentido. Assim, é o corpo que experimenta. Vejamos os versos: "tu queres dizê-los/ tacteias, sugas, redizes." (versos 23-24); “alguém a poisou e ao mar/ debaixo dos meus passos." (versos 29-30); "Terceiro nome/ que tem a força para separar,/ de um lugar de mães, o espaço lateral/ de outro, de outrem, o tacto do mar,/ trocado pela tua mão que tacteia./ Cantas, ouvido das palavras, tacto,/ flosa, pássaro cantante, depois/ de teres sido o primeiro pássaro." (versos 45-46-47-48-49-50-51). "Perto do mar/ a tua boca toca-lhe e toca-me." (versos $55-56)$.

E, nas outras estrofes: "Tens de tactear os meus olhos/ com o toque do mar." (versos 73-74); "Meu poeta, quem? Aquele que fala/ com as assonâncias, analogias,/ o uníssono e o tacto," (versos 85-86-87); "tu poisaste o teu pé/ nas pegadas do mar,"(versos 93-94); "Quando tu me tocaste, no mar,/ assinalavas as tuas marcas,"(versos 115-116); “a ver mãos moldarem o mar,"(verso 188); “Som, palavra dada, do abstracto ao tacto/ do meu ouvido.”(versos 234-235); “Criança, a tua mão de areia/ construiu a praia. Os teus dedos sonoros chamam-me agora." (versos 255-256257); “Aceita a água que vem/ para os teus pés," (versos 260-261).

Já no primeiro poema publicado, "Grafia 1", o gestual, a presença das mãos aparece: "as mãos derrubam arestas/ a palavra principia", que podemos relacionar ao poema de Sophia, citado por ela na entrevista comentada. O título do poema é: "As minhas mãos" e os últimos versos: "Arranco o mar do mar o ponho-o em $\mathrm{mim} / \mathrm{E} \mathrm{o}$ bater do meu coração sustenta o ritmo das coisas." (ANDRESEN, 1995, p. 164).

Na entrevista citada acima, Fiama, em sua reflexão sobre a poética de Sophia de Mello Breyner Andresen, escreveu: "Por mim, no poema, acabei hipostasiando os 
termos do dilema: união hipostática de coisa e nome e imagem, mesma substância. Matéria para o tacto, onda sonora para o ouvido, onda cromática para os olhos; três entificações e um só Ser verdadeiro.” (BRANDÃO, 1988, p.82).

Ficamos, então, com as três principais imagens do poema: o mar, a flosa, e o tu. Aliás, as três palavras que a poeta primeiro tem. E o tato para mostrar proximidade e concretude em relação à realidade.

Vamos sondar as imagens que a poeta nos propõe, em etapas, por estrofes.

\section{Primeira estrofe}

Ouves cantar a flosa, e erras,

não é ela, era o mar antes criado,

era a galáxia, o teu cérebro, aquela

que já ouviste ao aprenderes a fala.

Esta ao menos tiveste de a ouvir,

a do primeiro nome, no regaço

da tua mãe equívoca, mulher

e voz, mulher e luz, seio,

rumor, adejo. Se ouviste cantar

a flosa contra o fundo murmúrio

do mar, foi porque também depois

o bebeste na matriz da carne

ou na dos astros - a tua mãe de berço, 
a Natureza - no seio falador, no mamilo

astral, das palavras mar, murmúrio.

tão roucas como a palavra flosa,

as do primeiro dia da tua fala,

dia a dia, quando antes vagias

tal como as tuas mães, no berço,

antes do seio, antes do grande Cosmos.

A palavra que abre o poema é um verbo, na segunda pessoa do singular, no presente do indicativo, que significa e recorre ao sentido auditivo: "ouves". O tu pode se referir à realidade, por causa do título do poema; ao leitor, porque ao lermos nos colocamos no lugar de interlocutor; e também ao eu poético porque a interlocução se faz entre vozes íntimas. Essas possibilidades se mostrarão ao longo do poema. O que nos chama a atenção é a presença da segunda pessoa do singular, portanto há um interlocutor íntimo do sujeito poético.

O significado do verbo, erras, é ambíguo, tanto pode ser o contrário de "acertas", como pode ser usado no sentido de "andar sem rumo certo", "vaguear", e, ainda "espalhar-se". O significado que primeiro nos ocorre está relacionado a erro, mas percebemos que este é ampliado e engloba outras possibilidades. Contudo, o segundo verso limita nossa leitura, é categórico: "não é ela"; a tentação é guardar as outras possibilidades porque é extremamente atraente relacionarmos o ouvir o canto ao vaguear, ou a ave a voar e espalhar o canto e as sementes.

Nega, portanto, a possibilidade de o som ser o que se ouviu, - não é. Retoma com o verbo ser no pretérito imperfeito: era, e com o advérbio de tempo: antes. Evoca a ancestralidade, anterior ao mundo organizado - momento anterior à criação da flosa: "mar antes criado". Eduardo Lourenço, no prefácio de Obra Breve, escreveu: 
Um mundo anterior ao mesmo tempo anterior ao olhar e esperando por ele para ser decifrado. (...) Um mundo anterior ao verbo que o descreve e convoca, que nunca foi nomeado fora da voz que no-lo diz. Melhor seria dizer, do poema que o cria pela sua respiração. (LOURENÇO, 2006, p. 7).

O ouvir o canto da flosa não se limita ao canto da espécie, é um som que circula no tempo e no espaço, na concretude e na memória. Como Lourenço sintetiza sobre a obra de Fiama.

A poeta alude a uma ancestralidade, a um princípio anterior a tudo, ao tema do mito, das transformações quando afirma que "era o mar antes criado" - era o Caos? Em Metamorfoses de Ovídio, nos primeiros versos lemos, em tradução de Bocage: “Antes do mar, da Terra, e céu que os cobre/ Não tinha mais que um rosto a Natureza:/ Este era o Caos, massa indigesta, rude,/ E consistente só num peso inerte.” (OVÍDIO, 2007, p. 39). Por outro lado, lembramos que, no Genesis, o mar fora criado antes que os pássaros, portanto quando a autora escreve: "era o mar antes criado", pode estar se referindo ao momento anterior em que o mar foi criado, e o canto que não é da flosa pode ser também o som do mar, porque este foi criado primeiro, de acordo com o mito da Criação. Então, a poeta nos leva ao momento da Criação, antes das imagens organizadas, devidamente conceituadas. Mas ela não cita um elemento independente de seu contexto cósmico, pois as palavras denotam e conotam uma realidade cósmica da qual fazemos parte. Então, esse momento ancestral refere-se a um momento anterior à criação do sujeito como poeta. Ela compara a ancestralidade do mundo à dela enquanto sujeito poético, desde seus primórdios. É "uma espécie de fenomenologia do falar antes da fala" (LOURENÇO, 2011, p.8).

Se, por um lado, há essa busca da ancestralidade, de um momento primordial de Fiama como sujeito poético, por outro, Bachelard, citado por Barthes (2004, p. 40), escreveu que "a imaginação poética é um poder que desfaz as imagens". Fiama descreveu grandes temas poéticos: por exemplo, o do labirinto, do voo, da ascensão, da queda etc.; ou seja, produz na interioridade do próprio corpo o movimento mesmo da imaginação poética, que é um movimento essencialmente libertador. O que queremos dizer é que não há nenhuma interpretação limitadora nas palavras de Fiama; há, ao 
contrário, uma profusão de possibilidades que se agrega e não se elimina, como aparece nessa primeira estrofe.

Em “Teoria da Realidade", o canto não é anterior ao olhar, mas ao ouvir, há o particípio de criar: criado - "o mar antes criado". Depois: "era a galáxia", outra realidade simultaneamente ouvida, a poeta sugere o espaço - o amplia, sai da terra, refere-se a outra dimensão. Em "galáxia"31 não é o caos; já há uma organização, uma conceituação, embora nebulosa. Então, temos a alusão ao tempo da criação, tempo mítico, e alusão ao espaço sideral, a galáxia - sistema estelar isolado no espaço cósmico, ao qual pertencem o Sol e mais de cem bilhões de estrelas, nebulosas, aglomeradas, poeira e gás: Via Láctea. Portanto galáxia é o espaço nebuloso, também mítico. Podemos acrescentar ainda como um lugar sem centro.

Na primeira estrofe, depois dessas referências, volta para o "teu cérebro", no terceiro verso; retoma o espaço "aqui/ agora”, reduz ao ser, ao cérebro do interlocutor, da voz que ouve esses cantos fundidos, o canto da Realidade. Parte do microcosmo, vai ao macrocosmo e volta.

Parafraseando o poema, parece que ao ouvires (o tu) o som da flosa, não é apenas esse som que ouves cantar, mas também "o mar antes criado", a "galáxia" e "o teu cérebro" e "aquela/ que já ouviste ao aprenderes a fala." Referência ao princípio do tempo do eu poético, novamente. Então, aquele canto ouvido não é só o da flosa, mas é o canto do mar (que foi criado antes), da Galáxia, era o cérebro do interlocutor em que esses cantos se fundiam à fala daquela que ele ouviu, daquela com quem aprendeu a fala. Trata-se de discernir no sujeito poético que aquele canto não é apenas o canto da flosa, mas nele estão fundidas outras vozes, outros cantos.

\footnotetext{
${ }^{31}$ Como curiosidade, associo "galáxia" ao livro de Haroldo de Campos, chamado Galáxias, escrito ao longo de treze anos (1963-1976). Em Portugal, amostras do livro Galáxias foram estampadas no caderno o tempo e o modo do Brasil (Lisboa, Livraria Moraes, 1967) e na efêmera revista Nova, no. 1 (Lisboa, 1975/76), dirigida por Herberto Helder. Severo Sarduy escreveu na orelha da 2a. edição, 2004: "galáxia en que no hay centro, ni siquiera por su ausencia, (...). No se trata pues de un universo en expansión a partir de un big bang inicial, (...), sino de un universo en estabilidad a creación autónoma constante, sin origen y a partir de nada, cuyo suporte funcional es la diferencia y cuyo motor la repetición." (Severo Sarduy, 1972).
} 
Retomando o poema "Teoria da realidade: tratando-a por tu" e ao quarto verso: “aquela/ que já ouviste ao aprenderes a fala.", podemos dizer que há, no diálogo proposto pela autora, no canto da flosa, um resgate à memória porque, quando ouvimos a flosa além de se referir a outro tempo e espaço: "o mar antes criado" e "galáxia"; também se refere à memória, é aquela voz (canto) que já ouviu, na infância, "ao aprenderes a fala". Afinal a poeta partiu do macrocosmo, foi ao microcosmo: "teu cérebro" e chega à memória. Então, ao ouvir a flosa, não escutamos apenas seu canto, mas nos remetemos a uma ancestralidade anterior, à criação do mar, ao espaço cosmogônico, ao universal, ao individual e às memórias.

No canto da flosa, então, está contido todo esse universo que a poeta faz referência, além da memória. Só constatamos e identificamos o canto da flosa porque no nosso universo houve um canto anterior, do contrário nem o perceberíamos. No primeiro momento, assumimos o papel de interlocutor da poeta, porém, entendemos que, a segunda pessoa do singular, o tu, é o sujeito poético porque está se referindo ao seu processo de criação, criação da construção do poético, podemos chamar de sujeito em formação.

A flosa é aquela que canta, podemos relacionar ao canto das Musas em Teogonia, de Hesíodo. Se fosse uma epopeia, seria a invocação, o aedo dirige-se às musas para que o auxiliem na criação de sua obra, no caso, o diálogo se estabelece entre sujeitos e interlocutores presentes no mesmo ser. Há duas situações nesse início de poema: tu ouves e ela canta.

A autora reforça a ideia de ancestralidade, e retorno ao primordial e à matriz, primeiro pelo advérbio "antes", do segundo verso, e depois, por palavras que se referem ao primeiro, ao maternal: "primeiro nome", "bebeste na matriz da carne ou na dos astros"; "a tua mãe de berço"; "no seio falador"; "no mamilo astral”; "as do primeiro dia da tua fala", "as tuas mães"; "antes do seio"; "antes do grande Cosmos".

O último verso, "antes do seio, antes do grande Cosmos.", corrobora a leitura que Fiama fez de Metamorfoses, e de outros mitos da Criação. "Grande Cosmos" é o mundo criado, em harmonia, é um princípio organizador, a gênese do mundo. A palavra pode ser esse princípio organizador.

Essa primeira estrofe busca imagens e palavras para descrever a tentativa de encontro com o momento primordial da percepção da realidade nela, onde e quando 
aconteceu o reconhecimento da palavra anterior à fala poética. Quando a realidade se torna primeiro som, depois palavra. Há uma matriz, mãe, seio falador, no mamilo astral, que possibilita o ouvir e aprender a fala; reconhece os sons ou significantes: "das palavras mar, murmúrio./ Tão roucas como a palavra flosa,/ as do primeiro dia da tua fala,". Mas "Ainda estás muda". O eu poético sabe que ao ouvir "cantar a flosa" não é só ela que ouvimos, mas também "o mar antes criado", a galáxia e o "teu cérebro". Sabe da dificuldade de encontrar sua palavra dentro de tantas referências, mesmo que fundamentais para sua voz poética.

Refere-se à mundividência do sujeito poético, ao olhar, ou ouvir - que vê o mundo e quer descobrir, tirar os véus; desconfia. Mostra-nos como a consciência da percepção do real se gera nele.

Assim como a flosa aparece na primeira parte do poema, há outra imagem fundamental, que acompanha todas as estrofes, é a do mar, que comentaremos mais para frente. Apontamos a questão da ancestralidade em "era o mar antes criado"; é ressaltado também o mar como som peculiar que faz e como significante em: "Se ouviste cantar/ a flosa contra o fundo murmúrio do mar" e "das palavras mar, murmúrio." A poeta atrainos para a sonoridade através da palavra murmúrio próxima à palavra mar, reforça usando itálico nessas duas palavras e através da sequência dos fonemas nasais: "cantar/ a flosa contra o fundo murmúrio do mar"; "no mamilo/ astral, das palavras mar, murmúrio."

Associamos a flosa de Fiama ao rouxinol de Keats, porque existem semelhanças no tratamento dessa imagem e, para corroborar a ideia, sabemos que a autora foi leitora de Keats.

Lembramos do poema: Ode to a nightingale de Keats. Reproduzo aqui a estrofe VII:

Thou wast not Born for death, immortal Bird

No hungry generations tread thee down;

The voice I hear this passing night was heard

In ancient days by emperor and clown:

Perhaps the self-same song that found a path 
Through the sad heart of Ruth, when, sick for home,

She stood in tears amid the alien corn;

The same that oft-times hath

Charm'd magic casements, opening on the foam

Of perilous seas, in faery lands forlorn. ${ }^{32}$

Jorge Luis Borges (1998, p. 104) escreveu sobre esse poema: "Keats, no jardim suburbano, ouviu o eterno rouxinol de Ovídio e de Shakespeare, e sentiu sua própria mortalidade, e contrastou-a com a tênue voz imorredoura do invisível pássaro. (...)”." Assim como Keats ouviu no rouxinol cantado outro rouxinol, eterno, a flosa de Fiama a faz recordar a eterna flosa, "era o mar antes criado". Por um lado, o mar fora criado antes da flosa; por outro, ao ouvir a flosa, não era ela, "era o mar antes criado,/ era a galáxia, o teu cérebro, aquela/ que já ouviste ao aprenderes a fala." No canto dessa flosa, há inúmeras referências pessoais e literárias.

Podemos fazer a associação entre a flosa de Fiama e o rouxinol de Keats porque a flosa no poema não se limita ao tempo e espaço do poema, assim como o rouxinol de Keats. Fiama constata como a realidade é percebida - a busca desse momento inicial.

Para não ficarmos apenas na imagem do pássaro, transcreverei versos de Fiama em que ela tratará da rosa, em "Rosas, rosas e lírios": "Porém, pensar que a rosa apazigua:/ diria que era rosa, una, e que era a espécie.” (2006, p.113). É a questão comentada acima, em relação, aqui, à imagem da rosa: a rosa representa ela mesma, com toda singularidade e unidade, e também a espécie. Acrescento ainda a visão do poeta e do leitor, com suas próprias experiências, assim também a flosa significa além/ aquém do que vemos e/ ou ouvimos.

32 Tradução de Augusto de Campos (1987: 148-149): "Tu não nasceste para a morte, ave imortal!/ Não te pisaram pés de ávidas gerações;/ A voz que ouço cantar neste momento é igual/ À que outrora encantou príncipes e aldeões:/ Talvez a mesma voz com que foi consolado/ O coração de Rute, quando, em meio ao pranto,/ Ela colhia em terra alheia o alheio trigo;/ Quem sabe o mesmo canto/ Que abriu janelas encantadas ao perigo/ Dos mares maus, em longes solos, desolado." 
Fiama foi leitora de Keats, inclusive escreveu seu epitáfio em "Memorando para mim própria pensando em Keats”: “Aquele cujo nome foi escrito na água aqui jaz’/ são palavras de Keats para a sua própria laje.” (BRANDÃO, 2006, p. 601).

Enquanto John Keats ouvia o rouxinol, ao anoitecer de Hampstead, Fiama Hasse Paes Brandão ouvia a flosa cantar no inverno português, em Carcavelos e, nela, o canto de toda a realidade.

Fiquemos com a associação desses dois poetas, no sentido apresentado.

\section{Segunda estrofe}

Ainda estás muda, mas ouves

cantar um nome, ouviste já

dois nomes, tu queres dizê-los,

tacteias, sugas, redizes.

A primeira palavra já a dizes,

encastoada na substância do mar,

agora que puseram o mar todo

a teus pés, e ao dizer-te a palavra,

alguém a poisou e ao mar

debaixo dos meus passos. Alguém

é outra voz, além das vozes

ocultas, maternais, de outrora.

Alguém não é um eco, é a terceira

fala, mensageiro sem início, 
apenas boca presente, junta,

que veio nascer contigo. Nunca

teu gémeo, ou duplo, apenas de um lugar,

ali, alguém no espaço, contigo, a ouvir.

Enquanto a primeira estrofe começa por: "Ouves cantar a flosa, e erras", a segunda começa assim: “Ainda estás muda, mas ouves". O “ouvir” é fundamental nesse diálogo. Há um interlocutor próximo, íntimo da voz poética.

Então, na segunda estrofe, o "tu” que ouviu cantar a flosa, ainda está mudo, mas ouve cantar um nome, já diz a primeira palavra "encastoada na substância do mar", ou seja, o a é a letra que está no meio da palavra mar, assim como a primeira palavra do poeta nascente está encastoada na substância do mar. Com os termos "agora" e o mar que está a "teus pés" traz o momento presente e a concretude, confirma um sentido real. O mar que banha as coisas da realidade envolve tudo. O tu está envolvido pela realidade.

$\mathrm{Na}$ segunda estrofe, marcas da voz ou do sujeito poético aparecem, pela primeira vez, em primeira pessoa, no pronome meus - "meus passos". Surge "alguém" e a voz explica: “Alguém é outra voz, além das vozes ocultas, maternais, de outrora./ Alguém não é um eco, é a terceira/ fala, mensageiro sem início,/ apenas boca presente". Esse alguém passa a fazer companhia ao tu, esse alguém não tem início, boca presente. Quem é esse alguém? A mensagem? E o tu, é a realidade? Sabemos que é alguém que fala. Também é poeta. Penso que pode ser Sophia em Coral. Sophia de Mello Breyner Andresen pode estar entre os poetas que Fiama define como alguém, como terceira fala, como outra voz. É a questão da intertextualidade que nos propõe.

Por que Sophia? Em um artigo que Fiama escreveu em 1988, na revista $A$ Phala - um século de poesia, refere-se ao impacto causado ao ler o livro de Sophia em 1950, ano de publicação de Coral. Descreveu-o assim: "No verão de 1950, uma estranha onda de calor penetrou no interior das águas, pensei nesse momento". Nessa altura, Fiama tinha 12 anos. Ainda no artigo, afirmou que só encontrou a explicação 
poética cinco anos depois, em 1955, quando escreveu sobre seu processo de aprendizagem da língua:

As pequenas criaturas a boiar na superfície do tanque associaram-se, na aprendizagem da língua que a terceira pessoa levava a cabo - eu -, às coisas poéticas descritas pela autora de Coral e chamadas, por vezes, na página branca, peixes.

Era eu que estava a ler, no verso de Sophia, o fenómeno que cinco anos antes me enchera as pupilas - janelas da alma, para Hegel, na Estética - de espanto. Se a poetisa me surgiu logo como intérprete da língua materna quotidiana e escolar, com seu terceiro nome poético - o terceiro nome para todas as coisas -, eu começava, por meu lado, a compreender o seu próprio nome ôntico como filosofia e a realizar o primeiro passo filosófico entre as coisas e os nomes e o primeiro passo metafísico entre os nomes e o Nome.

Eis a aprendizagem fundamental: chamar $E u$ às coisas, minha primeira dívida a Coral.

Eu estava a aprender a língua - nascera em 1938, e nesses verões de cinquenta já lia os poetas para escolher os nomes das minhas imagens e ver, como poetas os haviam visto, os meus fenómenos. Logo vi, portanto, simultaneamente, que Coral além de, por vezes, chamar $e u$ às coisas, assinalava explicitamente - foi assim que eu li os versos dos peixes da prata! - a vaga de calor sensível que envenenara os peixes do meu tanque. Eis outra aprendizagem fundamental: a do livro arbítrio poético, que cada poeta recebe, como herança, da própria Poesia.

Voltando ao Coral, além do que fui sentindo, ou talvez sentindo o mesmo por outras palavras, esse livro mostrou-me logo que a autora não estava segura de muitos nomes da linguagem diária. A começar pelo título que afortunadamente apenas era ambíguo em dois sentidos. (...) Mas os versos, intrinsecamente melodiosos, falam-nos também repetidamente de melodia, melodia, som. Um mesmo verso repete-se, até, em dois poemas: ‘Tem dois búzios de mar sobre os ouvidos'. (BRANDÃO, 1988, p. 80) ${ }^{33}$.

\footnotetext{
${ }^{33}$ Este depoimento está em anexo. Em “A minha Poesia e referências" (1991) Fiama escreveu:" assim, passei anos de simples deslumbramento da leitura de um livro de poesia nacional, o Coral de Sophia de
} 
Embora a poética de Sophia aponte para algumas questões e a de Fiama para outras, o depoimento citado nos leva a analisar proximidades entre elas. Por exemplo, a questão da ambiguidade das palavras foi despertada, na poética de Fiama, através da leitura da poesia de Sophia de Mello Breyner Andresen, tanto que o sujeito poético usa o adjetivo ambíguo para qualificar o que foi gerado pela mãe: "Calada mãe, geraste tudo o que é/ ambiguo.”. É a questão, em poesia, das palavras sugerirem outras ou a questão da polissemia de palavras como mãe, tu e mar. Fiama comenta sobre o título do livro de Sophia: Coral, que "era ambíguo em dois sentidos". Ou seja, a questão, de a palavra poder ser ambígua foi despertada pela leitura do livro de Sophia. Também em relação aos versos melodiosos, por exemplo, no poema estudado, a autora ressalta a sonoridade em "mar, murmúrio", repete os versos: "Foi o mar" (versos 67 e 68). A intratextualidade, que Fiama leu em Coral, ela a pratica em sua poética. A escritora sugere, no texto acima, como se deu sua aprendizagem poética, seu livro arbítrio poético e como Sophia surgiu-lhe como terceiro nome poético, terceiro nome de todas as coisas.

Ressaltamos a importância de: "chamar $E u$ às coisas", "a do livro arbítrio poético" e a do terceiro nome poético, que aparece em "Teoria da Realidade, tratando a por tu”. São os autores que a influenciaram, que ela leu e essa leitura ecoa em sua obra. Está apontando para a questão da influência, como ressaltou Harold Bloom, ou, mais precisamente, da inspiração, como disse Roland Barthes (2005b, p.19):

Ora, o que busco, o que quero, na obra que desejo, é algo que ocorra: uma aventura, a própria dialética de uma conjunção amorosa, em que cada um vai deformar o outro por amor, e de modo a criar um terceiro termo: ou a própria relação, ou a obra nova, inspirada pela antiga.

Ela usa o termo "livro arbítrio", o que nos causa estranheza mas é o termo correto, são suas escolhas literárias. Quanto ao terceiro nome não é o nome puro e

Mello Breyner. A partir de então, desde Coral de Sophia de Mello Breyner, comecei a poder conhecer e ver o real e as coisas de uma forma poética. E desenvolvi a própria teoria da poesia." (ver anexos). 
simples de Sophia de Mello Breyner Andresen, mas a aventura de Fiama Hasse Pais Brandão ao ler Sophia e criar um terceiro termo ou nome, "a literatura não nasce de uma imitação direta, mas da proliferação, da enunciação do mundo como movimento de Espelhos." (BARTHES, 2005b, p. 22).

Antecipamo-nos à segunda estrofe de "Teoria da Realidade", e aos versos: “Alguém não é um eco, é a terceira/ fala, mensageiro sem início,/ apenas boca presente, junta,/ que veio nascer contigo." Na terceira estrofe: "Terceiro nome/ que tem a força para separar,/ de um lugar de mães, o espaço lateral/ de outro" e, na mesma estrofe: "E tu, terceira fala, também/ estranha, equívoca, quando tornas a tua fala um som." Chamanos a atenção a "terceira fala", "terceiro nome" que está presente no texto sobre Sophia.

Surge "alguém", que é a terceira fala. As vozes de outros poetas estão presentes e são fundamentais para a formação da voz poética. Caracteriza a terceira fala como "equívoca", isto é, como passível de apresentar mais de um sentido, compara à "mãe", ambas equívocas. Na terceira estrofe, "Flosa, o teu canto é confuso/ como o de minha mãe.", temos outra comparação entre o canto da flosa e o da mãe do sujeito poético. Aproxima os adjetivos: confuso e equívoco aos termos: mãe, terceira fala e o canto da flosa. Então, temos a ideia de confusão e equívoco ligada à flosa, à mãe e à terceira fala, anteriores ao canto da poeta. Essa ideia marca o estilo de Fiama, são desvios, tentativas de nomeação e renomeação, é assim que ela escreve.

Para aprofundarmos a ideia do que é terceira fala, emprestaremos as palavras de Carlos de Oliveira (2003, p. 44), de seu livro Finisterra Paisagem e Povoamento, (1 ${ }^{\mathrm{a}}$. ed. 1978), onde usa o termo terceira voz:

E a terceira voz? Existe realmente? Eco simultâneo das outras, sopra como o vento, parte as frases em palavras, as palavras em sílabas, as sílabas em gritos (fragmentos de sons). No entanto, o segredo da conversa não se estilhaça. Pelo contrário. Este processo misterioso desvenda-o sem lhe tocar: afasta ou rasga um véu (depende da intensidade) e o equívoco ( a sua imagem) surge compreensível. 
Curioso é observar que tanto Fiama, quanto Carlos de Oliveira utilizam os vocábulos: terceira voz e equívoco. A poeta usa "equívoco" como adjetivo, caracterizando a mãe e a terceira fala; enquanto no texto de Carlos de Oliveira, equívoco é substantivo. Parece que o equívoco, no texto de Carlos de Oliveira, surge compreensível se ouvirmos a terceira voz, que cruza com as vozes dos outros.

A terceira voz é a voz que se revela nos poemas, não é o poeta, ou seu passado, ou a língua de seus ancestrais, é a terceira voz, ou terceira fala. Não está nem em uma margem, nem na outra, mas na terceira margem. "Alguém é a terceira fala (...) que veio nascer contigo. (...) alguém no espaço, contigo a ouvir”.

O poema apresenta desde o primeiro verso a presença do outro, do tu, por consequência, a possibilidade de diálogo. Podemos pensar nos diálogos de Platão, que oscilam entre a narrativa, o lirismo e o drama, rompendo a regra rigorosa que prescrevia, outrora, a unidade do estilo. Num sentido moderno, os diálogos de Platão são uma mistura de vozes, são o que Baktin chamou de dialogismo. Baktin, de acordo com Barthes (2005, p.38): "Mikhail Baktin (1895-1975) pensou a linguagem e a criação literária menos como um código do que uma elaboração de uma intersubjetividade; a obra é uma polifonia, o dialogismo é o próprio princípio de toda a literatura.”

Confirmando o que Baktin afirmou, nessa estrofe, há uma interposição de vozes que fica evidente no verso: "Nunca, teu gêmeo, ou duplo, apenas de um lugar,/ ali, alguém no espaço, contigo, a ouvir." O diálogo se instaura com marcas de espaço. As pessoas podem ser: teu gêmeo, ou duplo, alguém e contigo. Os espaços são: um lugar, ali, no espaço. E o verbo é: ouvir. A marca de tempo é: nunca.

Nessa segunda estrofe, precisamos nos deter na questão do tempo. Temos os advérbios que se contrapõem, ainda e já, embora os dois estejam relacionados ao presente: "Ainda estás muda", “ouviste já/ dois nomes" e "A primeira palavra já a dizes". Parafraseando, ainda estás muda, mas já ouviste dois nomes, e já dizes a primeira palavra. Ou seja, o advérbio ainda, sugere que haverá, no futuro, um canto, mas ainda não aconteceu. O que aconteceu foi que ouviu dois nomes e disse a primeira palavra. A contraposição está entre as ações: estar muda, ouvir e dizer. Na primeira estrofe há o uso de antes se referindo ao anterior. O tempo já não é mais esse anterior, começa com o ainda, há uma expectativa que é sugerida pelo advérbio e acontece o 
ouvir e o dizer da primeira palavra. Essas ideias são reforçadas porque ela mantém a mesma estrutura nas duas estrofes. A realidade não se reduz ao presente. A realidade é tempo, e por isso talvez se possa ter tanta intimidade com ela, ela está ou é desde que a pronunciamos.

Outras marcas de tempo nessa estrofe são: agora e outrora. "agora que puseram o mar todo/ a teus pés", "Alguém/ é outra voz, além das vozes/ ocultas, maternais, de outrora.". O mar, imagem fundamental desse poema, foi colocado "aos teus pés", no presente; as vozes maternais pertencem, nessa estrofe, ao passado. Em relação ao nunca, outra marca de tempo, está relacionado a alguém, aos sujeitos que aparecem no poema; esclarece que nunca será "teu gêmeo".

Em relação às marcas de tempo, há uma linearidade, do passado para o presente, há uma comparação intrínseca entre nascimento e crescimento do ser humano e o aprendizado da palavra poética. Enquanto na primeira estrofe, predomina o antes: "era o mar antes criado"; "antes vagia"; "antes do seio"; "antes do grande Cosmos". Nessa estrofe, predomina o já: "Ouviste já"; "já a dizes”. Enquanto, na estrofe anterior, se falava de momento primordial, e só havia o ouvir e o vagias, nessa estrofe, há o dizer da primeira palavra.

Há um diálogo entre o tu e o eu, sujeito poético presente, com marcas de primeira pessoa do singular: "a teus pés, e ao dizer-te a palavra,/ alguém a poisou e ao mar/ debaixo dos meus passos." As marcas do sujeito poético, como primeira pessoa do singular, aparecem na segunda estrofe, enquanto as do tu, desde o princípio. O tu ocupa um espaço temporal maior, existe desde que começou esse poema. O sujeito poético, como primeira pessoa, começa a se manifestar, na segunda estrofe. Entretanto há a terceira pessoa, o alguém, "é a terceira/ fala, mensageiro sem início,/ apenas boca presente”. O alguém está além do tempo e espaço, atravessa os tempos. Seu corpo não existe mais, existem apenas suas palavras.

Nas estrofes que estudamos, há preponderância de um diálogo, a questão do sujeito é colocada e a do tu transposta, há referência a espaço pelas marcas presentes: um lugar, ali, no espaço. E o verbo é o ouvir, depois dizer. Então temos marcas de espaço, sujeito e interlocutores, é uma situação de comunicação. Há um locutor que fala 
com um tu, que pertence a um lugar; há um alguém que ouve juntamente com o interlocutor - tu.

Paul Celan, em $O$ Meridiano, discurso de agradecimento do Premio Georg Büchner, disse:

O poema torna-se - e em que condições! - o poema de um sujeito que insiste em ser um sujeito de percepção, atento a todos os fenômenos, e interrogando e apostrofando esses fenômenos: e torna-se diálogo, muitas vezes um diálogo desesperado.

Só no espaço desse diálogo se constitui o que é apostrofado, e se concentra à volta do $\mathrm{Eu}$ que a ele se dirige e nomeia. Mas essa entidade apostrofada, como que transformada em Tu pela nomeação, introduz também nessa presença o seu Ser-outro. Até no aqui e agora do poema - e o poema dispõe sempre apenas deste único e pontual presente -, até nesta imediaticidade e proximidade ele deixa falar aquilo que é mais próximo dele, desse Outro: o seu tempo.

Quando assim falamos com as coisas, confrontamo-nos sempre com a questão de saber de onde vêm e para onde vão elas: uma questão 'em aberto', 'que não leva a conclusão nenhuma', que aponta para um espaço aberto e vazio e livre - estamos muito longe, 'lá fora'. O poema, creio, procura também este lugar. (CELAN, 1996a, p. 57-58).

O sujeito poético ainda está mudo, mas ouve um nome. Começa a dizer a primeira palavra, relacionada à mar. A voz poética continua em formação e há a percepção da terceira fala, as vozes de outros poetas, da importância dessas vozes para sua formação como sujeito poético.

\section{Terceira estrofe}

Flosa, o teu canto é confuso

como o de minha mãe. 
E, já uma vez, num verso, eu te pus

a cantares-te a ti mesma, mas agora

é a mim que me falo. Este é

o mar, a fala de quem chamar,

a meu lado, o mar. Terceiro nome

que tem a força para separar,

de um lugar de mães, o espaço lateral

de outro, de outrem, o tacto do mar,

trocado pela tua mão que tacteia.

Cantas, ouvido das palavras, tacto,

flosa, pássaro cantante, depois

de teres sido o primeiro pássaro.

E tu, terceira fala, também

estranha, equívoca, quando tornas

a tua fala um som. Perto do mar

a tua boca toca-lhe e toca-me.

Começa o diálogo com a flosa e, por meio do adjetivo "confuso", relaciona o canto da flosa à mãe, que é equívoca. Em, "E já uma vez, num verso, eu te pus/ a cantares-te a ti mesma, mas agora/ é a mim que me falo.”. Fiama refere-se a versos do poema "Canto dos insectos", do livro Cantos do Canto (1995): "A flosa canta a sua identidade/ sem saber que é única neste espaço/ em que as aves, os animais e o poeta/ enquadram os insectos, em fase larvar./ Canto os que vão procriar na terra/ fermentada e os que já pairam aqui/ desde que me senti tão similar.” (2006, p. 555). Ou seja, em 
"Teoria da Realidade", a poeta comenta esse outro verso, onde a poeta pôs a cantar a flosa; aqui, vai falar sobre a formação de sua voz poética.

"Flosa, o teu canto é confuso/ como o de minha mãe", a poeta compara o canto da flosa ao da mãe, ambos confusos. Neste sentido, lembramos o que Fiama escreveu em Sob o olhar de Medeia: "Quando se calava ninguém existia” (1999, p. 61); "a mãe sempre parca em palavras" (1999, p. 63). A mãe da protagonista, na narrativa, é calada, parca em palavras, enquanto no poema, o canto da mãe é confuso, ou seja, não se distingue, não se capta com nitidez. A existência da personagem só poderia existir a partir do canto da mãe. Mãe aparece desde a primeira estrofe: "da tua mãe equívoca".

Nesta estrofe, o diálogo continua. Se, na primeira estrofe, a mãe é equívoca, agora o canto da mãe é confuso como o da flosa, que já havia anunciado como tal, aqui aparece o "terceiro nome/ que tem força para separar,/ de um lugar de mães, o espaço lateral /de outros". Não estamos mais no mesmo lugar, há o terceiro nome. Além do canto da mãe, há outras interferências.

Por um lado, há um ritmo marcado pelo som /t/: "Terceiro nome/ que tem a força para separar,/ de um lugar de mães, o espaço lateral/ de outro, de outrem, o tacto do mar,/ trocado pela tua mão que tacteia." Esse som transmite a força que separa, delimitando o espaço.

Por outro lado, há uma concretude que se estabelece pelo tato: "o tacto do mar,/ trocado pela tua mão que tacteia" - interessante o movimento que aparece nesse verso, o tato do mar é trocado pelo tato de tua mão ${ }^{34}$. O espaço ampliado se concentra em "tua mão que tacteia", mostra o gesto hesitante da mão. O som do "t" causa uma quebra que, ao mesmo tempo, tem uma força sonora e lembra o tato relacionado ao palato, a língua bate nos dentes, o toque da língua no céu da boca.

O poema continua: "Cantas, ouvido das palavras, tacto,/ flosa, pássaro cantante, depois/ de teres sido o primeiro pássaro./ E tu, terceira fala, também/ estranha, equívoca, quando tornas / a tua fala um som. Perto do mar/ a tua boca toca-lhe e toca-

\footnotetext{
${ }^{34}$ Agradeço a Gastão Cruz sua leitura precisa, uma vez que fiquei na dúvida entre as palavras trocado e tocado: "o tacto do mar/ trocado pela tua mão que tacteia.".
} 
me." O tato é privilegiado e os adjetivos: confuso (o canto da flosa), estranha e equívoca (a terceira fala), que já apareceram para caracterizar "a tua mãe".

Nesta estrofe, o tu se manifesta como terceira fala. O ritmo é marcante. "Este é o mar". O lugar está denominado. "Perto do mar/ a tua boca toca-lhe e toca-me." Ou seja, se aqui é o mar, perto daqui, a terceira fala toca o mar e toca o sujeito poético. A terceira fala escreve sobre o mar e com isso toca o sujeito poético. O mar está presente, já estava em Sophia, a terceira fala, a fala do poeta circula e toca-lhe também, hipostasiando-a. Continua o percurso da descoberta de sua voz poética, consciente de outras vozes (terceiro nome), da concretude das palavras, aparente na sensação do tato que traz para o presente, para o concreto. A fala é agora um som que toca o mar, a outra voz e a dela.

Quanto ao tato, há muitos versos de Fiama espalhados por Obra Breve, ficamos com dois: "Oxalá eu fosse algum dia cega para os olhos,/ visse apenas o tacto, o ouvido, o gosto." (2006, p. 297), de Área Branca (1978). Em Cenas Vivas (2000): “Hoje ou agora, os meus olhos/ são somente como o tacto: apalpam,/ marcam, com a sua secreção,/ o rebordo de cada objecto, dos seres,/ o limite de uma crónica dos dias." (2006, p. 632).

O tato é um dos sentidos em que usamos o corpo, as mãos para perceber o objeto. É o que apela para a materialidade, a concretude, o imanente. É o gestual, presente nas artes teatrais e na dança. É o espaço do corpo. "A pele tornada espaço". (GIL, 2005, p. 47).

E o tempo não existe quando tudo se reúne.

Mas as frases de todos estão no lugar, meus poetas,

Sendo o olhar sempre o puro tacto, quando o som

Sai desta boca, sopro, e toca em sons e seres.

A faixa solar vermelha é um profundo fundo, só sonoro

E tangível na boca.

(Brandão, 2006, p. 707) 
A terceira fala toca o sujeito poético e o mar. Como interseção, entre o sujeito poético e a terceira fala, há o mar.

\section{Quarta estrofe}

Três são as palavras comigo -

a flosa, o mar, e tu. Estou

ou sou debaixo do fascínio

deste tríplice tudo. (Agora

tenho em mim o tempo instilado

pela fala mútua e pelo ouvido.)

E com as três palavras posso

ouvir essa poderosa voz,

que era, além, um poeta,

depois de, como eu, ter bebido

o leite da palavra. Foi o mar.

O sujeito poético tem três palavras consigo: a flosa, o mar e tu. As três principais imagens desse poema, com toda a polissemia dessas palavras. Com as três palavras pode ouvir essa voz poderosa que era um poeta, depois de, como sujeito poético, ter bebido o leite da palavra.

Essas palavras fazem a síntese do que até agora foi apresentado, anunciam a visão de mundo dessa poeta que percorre a estrada de conhecimento e reconhecimento da palavra poética, da sua palavra poética. 
Três é um número fundamental universalmente, é a perfeição, a totalidade, de grande expressão em todas as tradições, tanto no Cristianismo ( a divina trindade), como na Cabala ( a lei do ternário), para ficarmos apenas nessas. De acordo com Chevalier \& Gheerbrant (2002, p. 899): “o três exprime uma ordem intelectual e espiritual, em Deus, no cosmo ou no homem. Sintetiza a triunidade do ser vivo ou resulta da conjunção de 1 e de 2, produzido, neste caso, da União do Céu e da Terra.”. Nesse poema, aparece como numeral cardinal e ordinal.

Retomando as três palavras "fundadoras" e os significados, temos, em uma breve síntese: a flosa representa mais que um pássaro migratório português; o mar é elementar no imaginário lisboeta, tanto em relação à experiência da autora como na de outros poetas que a inspiraram, e está relacionado à história de Portugal. O tu, por fim, realiza o diálogo, do mais banal ao mais profundo, representado pelo amor. Às vezes, podemos relacioná-lo à realidade, em outras ao leitor e ao sujeito poético. Depois, na nona estrofe, versos 141 e 142, o tu será substituído por mãe: "Flosa, mãe, mar, em que versos/ somente sois palavras minhas?",

Agora o sujeito poético nascente tem três palavras: "Três são as palavras comigo -/ a flosa, o mar, e tu." Sente-se fascinada com a sensação de totalidade representada pelo número três: "Estou/ ou sou debaixo do fascínio/ deste tríplice tudo." Estou ou sou é uma questão da transitoriedade, enquanto o estou representa o momento presente, o sou continua no tempo, portanto sugere uma relação de tempo e espaço. Normalmente, a fascinação costuma acabar, dura pouco, no poema, o sujeito poético é fascinado ou está fascinado pelo sentido das palavras, de como podem representar a totalidade, como o número três, e como essas palavras que já têm representam uma totalidade de mundo. A questão está nas palavras que ele têm e com a simbologia do três, que experimenta como unidade.

O sujeito poético explica todo seu processo criativo: "( Agora/ tenho em mim o tempo instilado/ pela fala mútua e pelo ouvido.) Sua voz se faz pela fala mútua, compartilhada - pelo diálogo e pela escuta, desde o "Ouves cantar a flosa".

"E com as três palavras posso/ ouvir essa poderosa voz," Essa poderosa voz refere-se a "um poeta,/ depois de, como eu, ter bebido/ o leite da palavra." Como o sujeito poético, bebeu o leite das palavras, na primeira estrofe, e na vida. "Foi o mar." 
Repete o verso: "Foi o mar", como lhe tinha chamado a atenção no poema de Sophia. A assonância se faz pela repetição do verso e por: as, três, palavras, posso, essa, voz. Na sexta estrofe, ressaltará o poeta que "fala/ com as assonâncias, analogias,/ o uníssono e o tacto".

O sujeito poético tem as três palavras, já é e está fascinada "debaixo deste tríplice tudo", já existe por si mesma, tem "o tempo instilado pela fala mútua e pelo ouvido", e pode ouvir "essa poderosa voz" de outros poetas. Termina com o verso "fundador": "Foi o mar". Assim também começa a próxima estrofe à maneira de um "leixa-pren", confirmando a importância da palavra e da substância "mar".

\section{Quinta estrofe}

Foi o mar, ó mar salgado,

e quantas das águas serão

as lágrimas de Portugal. Agora

tens de saber o que podemos ser:

águas, lágrimas, o Portugal.

Tens de tactear os meus olhos

com o toque do mar. Era criança,

e de súbito o mar foi o sinal

da palavra nova, o ser da água

ou das águas, similares

no $a$ vivo, a mais audível

nascente do alfabeto, o eco. 
Nesta estrofe, o poeta revelado é Fernando Pessoa de Mensagem. O que podemos ser? águas, lágrimas, o Portugal. Era criança e o mar foi o sinal da palavra nova. É o ponto de partida, o "spunto" de sua poética e desse poema, que é uma arte poética.

Fiama dialoga com a tradição poética portuguesa: "ó mar salgado,/ e quantas das águas serão/ as lágrimas de Portugal." Refere-se ao poema "Mar Português", "X”, de Fernando Pessoa, do livro Mensagem: "Ó mar salgado, quanto do teu sal/ São lágrimas de Portugal!”, que, por sua vez, retoma o episódio do Velho do Restelo, de Camões em Os Lusíadas. Há um retoque em relação ao verso pessoano. Enquanto, em Mensagem, o verbo está no presente: são, referindo-se ao mar das descobertas, onde muitos filhos de Portugal morreram, no poema que estudamos, o verbo está no futuro. atualizando a história portuguesa. Quando o poema foi escrito, as lágrimas estão relacionadas às guerras coloniais e às perdas que houve em Portugal. Podemos ler “quantas das águas serão/ as lágrimas de Portugal”, não como futuro propriamente dito, mas como valor hipotético: quantas das águas não serão as lágrimas de Portugal, ou ainda, quanto haverá de lágrimas e quanto mar! Então Mensagem e Os Lusíadas apresentam-se como Livros-Chaves, pois, na denominação de Barthes (2005b, p.114): "Livro-Chave: aquele que parece permitir a compreensão de um país, de uma época, de um autor."

Há uma afirmação: “Agora/ tens de saber o que podemos ser:/ águas, lágrimas, o Portugal.” É preciso “estar presente", não saudar um tempo glorioso, esse não existe mais. É preciso renascer, assim como a poeta. "Tens de tactear os meus olhos/ com o toque do mar." Essa estrofe, por meio do verbo ser, em diferentes tempos verbais, trata da questão do ser, do nascimento, do renascimento, de uma nação, de um ser, de um poeta. A ideia de princípio aparece pelas palavras: criança, palavra nova, nascente do alfabeto, no $a$ vivo. O $a$ é a primeira letra do alfabeto, o primeiro som, podemos associá-lo ao som primordial. Além das três palavras que lhe pertencem, a poeta apresenta-nos outra referência histórica e poética: Fernando Pessoa e a história de Portugal.

"Tens de tactear os meus olhos/ com o toque do mar" - tactear e toque representam atitude concreta, física e o mar é o estopim para o mergulho na palavra 
poética, desde criança, como ela escreve nos versos seguintes: "Era criança,/ e de súbito o mar foi o sinal/ da palavra nova, o ser da água/ ou das águas, similares / no $a$ vivo, a mais audível/ nascente do alfabeto, o eco.”Ou, também como Fiama contou sobre o impacto que a poesia de Sophia teve sobre ela, quando criança: "uma estranha onda de calor penetrou no interior das águas." A inspiração da poética de Sophia na poética de Fiama se nota, além das anotadas acima, pela metáfora do mar, das águas.

Conferimos a importância outorgada ao primeiro, ao primordial através da imagem de criança, pela palavra nova e pela primeira letra do alfabeto, "o a vivo"; a surpresa, representada por súbito, que, de alguma forma, está relacionada ao não esperado, não previsto, portanto visto/ ouvido pela primeira vez. Criança traz como atributo a ideia de renascimento.

Ao longo do poema, a palavra "mar" é-nos mostrada como uma realidade, depois um lugar, ou cenário; depois como palavra; como se a realidade engendrasse poesia no sujeito poético e consequentemente no leitor. Nessa estrofe acontece essa transformação através da palavra mar.

Temos a imagem de um nascimento através da água/ mar. E o som que assimila como um sinal deste "nascimento" é o $a$, primeira vogal, o primeiro som, presente na palavra mar, em água, em sal. É o som de abertura, por isso associamo-lo ao "spunto" de sua poética, assim como aos versos inaugurais: "Água significa ave”, em “Grafia 1", publicado em 1961, primeiro verso, do primeiro poema, de Obra Breve Poesia Reunida, citado no segundo capítulo desta tese.

\section{Sexta estrofe}

E os meus olhos mostraram também ao mar as lágrimas com o $a$ de sal.

E o inteiro ouvido engendrou

a máxima palavra Portugal, 
tu, realidade, meu poeta.

Meu poeta, quem? Aquele que fala

com as assonâncias, analogias,

o uníssono e o tacto, os nomes

naturais matrizes guardadas

por sua mãe. O eu mais rápido,

criança que saiu do próprio berço

e se torna, ela mesma, elemento, pela fala,

ao ouvir palavras, das três

palavras minhas. Tão de repente,

realidade, tu poisaste o teu pé

nas pegadas do mar, disseste

águas, exorbitaste dos olhos,

e repetiste: lágrimas. Chamaste

a coroa das palavras, neste lugar:

a língua, no tempo de Portugal.

Esta estrofe é continuação da anterior, começa com E, enquanto a anterior termina por eco. "E os meus olhos mostraram também/ ao mar as lágrimas com o $a$ de sal." Há uma associação de ideias, pela matéria e pela palavra, assim como o mar tem sal, as lágrimas também, e, mar, sal e lágrimas têm o $a$ inicial. Portugal aparece como significante, rimando com sal, e por analogia, além de rimar com sal, também significa lágrimas e perdas, dentro do conteúdo semântico confirmado por esse poema e pelo engrandecimento da palavra ao longo da história literária. Sal também é o que dá sabor 
aos alimentos. Novamente a palavra, além do significante, traz um conteúdo que não se resume ao que se escuta ou se lê.

Há três palavras em itálico, destacadas: uma na estrofe anterior, o $a$, e águas e lágrimas. Uma palavra desemboca na outra, o a é inicial, reaparece em águas e lágrimas. É material poético, formação de poesia. O a é abertura e fechamento destas palavras.

Só nessa sexta estrofe, depois de lermos as cinco primeiras, aparece a palavra realidade, que nomeia o poema, em dois versos: "tu, realidade, meu poeta."; "Tão de repente, realidade, tu poisaste o teu pé/ nas pegadas do mar". É tratada por tu, demonstrando intimidade. No primeiro verso mencionado, realidade está vinculada a Portugal e a poeta, no segundo, está próxima, é tão concreta e próxima que tem pé, deixa pegadas, mesmo que no mar, portanto efêmeras. Podemos ler mar como metáfora também para a realidade.

Depois de teres tateado "os meus olhos" com o toque do mar, na estrofe anterior, nessa: "os meus olhos mostraram também/ ao mar as lágrimas com $a$ de sal." Os olhos do sujeito poético mostrarão as lágrimas ao mar, a relação se inverte, relacionando com o verso: "e quantas das águas serão/ as lágrimas de Portugal." O sujeito poético se junta às lágrimas de Portugal. Mostra suas lágrimas, mas não são lágrimas por uma dor física ou emocional. Sua emoção se origina na linguagem, na poesia. É “o $a$ de sal”, o $a$ inicial, ou seja, é a linguagem, que lhe fará verter lágrimas e mostrá-las ao mar.

Depois do tato e dos olhos, agora é o órgão da audição que "engendrou/ a máxima palavra Portugal", é o escutar Portugal, a sonoridade da língua e as questões pátrias. Portugal como palavra poética, como linguagem, como destino ou fado e como lugar.

Nessa estrofe, denomina a realidade, como "meu poeta", "Aquele que fala/ com as assonâncias, analogias,/ o uníssono e o tacto, os nomes/ naturais matrizes guardadas/ por sua mãe." Novamente a questão da mãe e da matriz, que é um tema da primeira estrofe. Surge, então, finalmente, a fala. Segue as pegadas de Fernando Pessoa em "Mar Português" (1996, p. 58) e em "Horizonte" (1996, p.48): "Ó mar anterior a nós, teus medos/ Tinham coral e praias e arvoredos." Retomemos o segundo verso do 
poema: "não é ela, era o mar antes criado". O mar, nesses dois versos, no de Pessoa e no de Fiama, o mar anterior a nós e o mar antes criado se assemelham; podemos dizer que, aqui, a autora refere-se ao mar de Fernando Pessoa.

Há a mesma questão de ver ao longe e depois nos aproximarmos e conseguirmos definir as linhas, as cores e sons e depois: "E, no desembarcar, ha aves, flores,/ Onde era só, de longe a abstracta linha.// O sonho é ver as formas invisíveis/ Da distancia imprecisa e, com sensíveis/ Movimentos da esprança e da vontade,/ Buscar na linha fria do horizonte/ A arvore, a praia, a flor, a ave, a fonte - / Os beijos merecidos da Verdade.” (PESSOA, 1996, p.48). Percorrendo esse poema de Fiama, vamos aproximando-nos mais da "terra firme" e vemos, ou escutamos, com mais nitidez; o nevoeiro se esvai. O sujeito poético está mais perto da realidade, da concretude.

"O eu mais rápido,/ criança que saiu do próprio berço/ e se torna, ela mesmo, elemento, pela fala,/ ao ouvir palavras, das três/ palavras minhas." Criança simboliza a possibilidade e o sujeito poético e é precoce. A partir da fala, ou seja, da expressão verbal, depois de aprender as três palavras do sujeito poético, se torna ela mesma poeta, se emancipa.

Em "Catábase e Peregrinação", a criança aparece, em maiúscula: "A Criança antes de ver não soube ver/ a aurora tingir e o dia amanhecer."; "Chamaram-na só com o seu desejo,/ igual ao da Criança que já vira/ o amor antes de ver o Mundo."; "Sou eu que sou Criança”. ( 2006, p. 684-685). Criança é uma metáfora de poeta.

"Tão de repente,/ realidade, tu poisaste o teu pé/ nas pegadas do mar, disseste/ águas, exorbitaste dos olhos,/ e repetiste: lágrimas. Chamaste/ a coroa das palavras, o nome/ de todas as palavras, neste lugar:/ a língua, no tempo de Portugal.” A poeta repete o processo do primeiro poema “Grafia 1”: “Água significa ave/ se/ a sílaba é uma pedra álgida/ sobre o equilíbrio dos olhos/ se/ as palavras são densas de sangue/ e despem objectos/" (1996, p. 15). A poeta se dá conta do poder das palavras, e de como uma palavra, ou às vezes, um som leva a outra palavra, a outro som que significa e sensibiliza. Esse procedimento é característico do estilo de sua poesia. O lugar está limitado pelo espaço e pela língua - Portugal. A poeta se localiza. O lugar é a língua e o tempo é Portugal. 
Em "O triplo nome Sophia” (1988, p. 82), Fiama depõe sobre o fazer poético e a questão dos sentidos, da coisa e do nome:

Matéria para o tacto, onda sonora para o ouvido, onda cromática para os olhos; três entificações e um só Ser verdadeiro. Simplesmente, os nomes são mais portáteis do que as coisas, mais leves, são miniaturas, frágeis mnemônicas. Terceiros entre os meus olhos e as coisas. (...). Vejo só o meu passado. Escrevo sobre ver-me. Pintar verbalmente a partir do ar que engulo. Desde uma determinada acumulação, numa determinada idade, não podemos engulir ar sem sons ou palavras - música ou fonemas. Toda respiração da maturidade é feita de O+P. $P$ por palavra, tal como, com escândalo, traduziu Erasmo Ao princípio era a palavra, colocando-a na terra, não para ser orgulhosamente roubada a Deus, mas, talvez, recusada aos senhores da terra e entregue aos Poetas e aos Teósofos (da sophia divina), como consolo da ausência do Nome.

É uma outra maneira de expor os meandros da criação poética.

\section{Sétima estrofe}

$\mathrm{Tu}$, realidade, és nome de ti

e do que os poetas fundam,

depois de terem a fala perfeita.

Tens na inspiração do ar o $a$ total

que une em si a boca dos poetas

tal como, em mim, o Camões ao de Estugarda.

Este fundou a fala já falada,

o canto refeito, que é legado.

Aquele leu o já lido, dobrou 
o antigo canto clássico. Mas,

ó minha palavra muda, pensada,

detém-te. Já falas nos poetas,

porém, em ti, só tens o ar,

além das tuas três palavras. Depois

da voz cansada, inspira o mar, repara

nas marcas da água. Narravas.

Os dois primeiros versos remetem-nos aos versos de Friedrich Hölderlin, no poema "Lembrança", de Hinos Tardios, reproduzimos a última estrofe na tradução de Maria Teresa Dias Furtado (2000, p. 119 -123):

E agora para a Índia

Partiram os homens

Além, do ventoso promontório

Junto aos montes de vinhedos, de onde

Desce o Dordonha

E juntando-se ao esplendoroso

Garona em amplidão marítima

O caudal termina. E o mar

Tira e dá memória,

E também o amor se apodera em fim dos olhos.

E os poetas fundam o que permanece.

Fiama aproxima seu poema ao do autor de Hipérion pelo último verso do Hino. Heidegger o imortalizou numa leitura hoje considerada clássica. Para Hölderlin, o que 
permanece na poesia é o que existe. Em Fiama, os poetas fundam a realidade só depois de terem a fala perfeita.

Para Hölderlin, os poetas fundam o que perdura. Heidegger considera a obra de Hölderlin como a poematização da "essência da própria poesia". Aprofundaremos esse conceito através do estudo que Marco Aurélio Werle fez de Heidegger sobre a poética de Hölderlin:

A noção de fundação poética pode ser tomada como a mais perfeita expressão do ser do poeta: "Mas a suprema expressão da essência do poeta, ele a anuncia no verso final da última estrofe do poema 'Recordar': "Mas, o que permanece, fundam os poetas".

Segundo Heidegger, "por um lado, fundar significa projetar adiante, em sua essência, o que ainda não é... levar o projeto à palavra...; por outro, designa fundação: reservar e salvar isso que assim foi antecipado e fundamentado enquanto uma recordação que permanece na essência aberta do ser, a cujo recordar um povo sempre novamente necessita se referir".

A primeira dessas duas vias aponta para 'um abrir caminho', dar um passo à frente, ao passo que a segunda aponta para um resguardo do que foi aberto. A primeira via ainda permanece quase totalmente mergulhada na indiferença da origem, ao passo que a segunda já requer um dizer estabelecido, algo que está mais próximo do povo sob esses acenos (dos deuses), isto é, um mostrar, um apontar, pelo qual os deuses se abrem... Poesia é fundação, fundamentação efetiva do que permanece. O poeta é o fundamentador do ser.

O dizer do poeta é fundação ... no sentido da sólida fundamentação da existência humana sobre seu fundamento.

O ato poético surge, assim, como uma tomada de decisão, relativa a um novo início histórico: 'poetizar - em latim dictare - significa assentar, ditar para que algo seja assentado. Dizer algo que antes não havia sido dito. Por isso, há no dizer poético um autêntico começo. (...) O iniciar constitui, assim, o aspecto inusitado da operação do poeta: a poesia autêntica sempre significa uma instauração que rompe com a mera continuidade. (WERLE, 2004, p. 82-84). 
Por meio dessa reflexão sobre o verso de Hölderlin, podemos entender com maior clareza o que é "que os poetas fundam, depois de terem a fala perfeita". O poeta não canta meramente o que está à frente, precisa de uma sólida fundamentação na existência humana. Há a questão do tempo, vem do passado, através da palavra recordar e projeta adiante, vai em direção ao futuro. A poesia não se resume ao presente.

Podemos associar, ou melhor, agregar, a essa ideia, a epígrafe de Rilke do começo deste capítulo, que também questiona a arte poética e o ser poeta colocando a experiência do autor, que está além das lembranças, como fundamental para a poesia.

Para discutirmos a questão da "fala perfeita" de Fiama, citaremos Rosa Maria Martelo (2004, p. 180-182), que escreveu "Fiama e a 'fala perfeita", sobre uma leitura do livro Cenas Vivas:

Linguagem e paisagem reúnem-se para transformar o real nesse mundo habitável, que a poesia transporta como se lhe coubesse por inteiro a inteira memória das imagens: "Tu, realidade, és nome de ti/ e do que os poetas fundam,/ depois de terem a fala perfeita”.

A imagem ( o que a poesia recolhe ou funda), se não substitui a visão do concreto na sua pura exterioridade, acompanha-a sempre num jogo de evocações e, por conseguinte, instaura uma relação de pressuposição recíproca.

O que pretendo dizer é que o olhar raso procurado em Cenas Vivas tem por detrás uma elaboradíssima experiência de leitura e de escrita que o subordina ao conhecimento da poesia, à vivência quase corporal dos sons e do sentido. (...), não devemos esquecer que esse olhar, que voluntariamente se sustém perante a evidência do real, apenas se tornou possível por ter atrás de si quarenta anos de uma biografia de poeta ciente da imensa herança proporcionada pela tradição artística, que Fiama ama com o mesmo deslumbramento com que vê voar os pirilampos.

Fiama não reduz a realidade ao presente, a realidade é tempo. A palavra que cria não vem do acaso, nem de hoje, ela é flosa e mar, lágrimas e sal, partidas e chegadas. Não existe um agora sem outrora. 
Heidegger escreveu sobre a poesia de Hölderlin: "La poesia despierta la aparencia de lo irreal y del ensueño, frente a la realidad palpable y ruidosa en la que nos creemos en casa. Y, sin embargo, es al contrario, pues lo que el poeta dice y toma por ser es la realidad." (HEIDEGGER, 2001, p. 143).

O poeta se destitui do convencional, inaugura, funda a realidade.

Referiremos agora a um aspecto peculiar de Hölderlin, observado por José Paulo Paes, na introdução de sua tradução de Poemas de Hölderlin. Chamou-nos a atenção sobre a questão da intimidade e do uso dos pronomes de tratamento, questão do poema que estudamos de Fiama, que desde o título de "Teoria da Realidade - tratando-a por tu", apresenta a marca do diálogo e da intimidade pelo uso do pronome pessoal: tu.

Hölderlin tratava sistematicamente os seus visitantes com extrema reverência (Vossa Alteza, Vossa Graça, Vossa Santidade), no final da vida. Roman Jakobson dedicou um minucioso estudo aos chamados "poemas da loucura" e, diante desses pronomes de tratamento que Hölderlin usava, disse que tinha por objetivo manter o mundo exterior à distância, assim como a adoção de um cognome era uma "tentativa de excluir o próprio eu do colóquio e mais tarde até dos escritos” (PAES, 1991, p. 52).

Se, por um lado, Hölderlin tratava os visitantes com reverência e com isso demonstrava o desejo de manter o mundo exterior à distância, por outro, chama intimidade ao que mantém as coisas separadas em conflito, mas que igualmente as reúne. A manifestação de pertencimento a esta intimidade acontece mediante a criação de um mundo, assim como por seu nascimento, sua destruição e sua decadência. Ao contrário desse Hölderlin, que se mantém à distância, Fiama quer proximidade, ao menos com a realidade.

A questão do diálogo é estudada por Heidegger na poética de Hölderlin:

Hagamos resaltar luego, en estos versos, lo de inmediato referido en el contexto hasta aquí discutido: 'Desde que somos un diálogo'... Nosotros los hombres somos un diálogo. El ser del hombre se funda en el habla; pero ésta acontece primero en el diálogo. (...). 'Desde que somos un diálogo...'. Desde que los dioses nos llevan al diálogo, desde que el tiempo es tiempo, el fundamento de nuestra existencia es un diálogo. La 
proposición de que el habla es el acontecimiento más alto de la existencia humana ha obtenido así su explicación y fundamentación. (HEIDEGGER, 2001, p. 134-136).

Como ponto de encontro entre a poética de Fiama e a de Hölderlin podemos aponta a importância da pátria, no poema analisado: "as lágrimas de Portugal”; "o Portugal"; "a máxima palavra Portugal"; "no tempo de Portugal". Hölderlin era visto como um poeta nacionalista. Retomemos o estudo de Paes sobre Hölderlin, na questão sobre nacionalismo, sobre a pátria, "o retorno à pátria" e relacionaremos à poética de Fiama:

Em sua análise e interpretação de 'Lembrança', Heidegger mostra que para o poeta 'a viagem ao estrangeiro é uma condição essencial para que se realize o regresso à pátria, regresso que o faz entrar na lei própria do seu canto poético. Mostra, outrossim, o filósofo serem 'os navegantes' mencionados na primeira estrofe os 'poetas vindouros da Germânia' que 'dizem o Sagrado' e fundam 'a história de sua pátria' ou polis como o 'lugar que o Sagrado assinala à história'.

Heidegger considera o fundar a essência mesma da poesia, que, numa definição hoje famosa, ele conceitua como a 'fundação do ser pela palavra'.

Os homens vivem comumente na apatridade porque, distraídos pelos cuidados miúdos do dia-a-dia, descuram da 'verdade do ser'. Já o poeta, ao regressar do estrangeiro à pátria, volta ao natal - lugar e momento da criação, origem onde o ser se entremostra na sua essência à iluminação poética. Trata-se, em suma, do lugar do universal, pois o conceito de pátria não tem nenhum sentido restritivamente nacionalista na poesia holderliana. (...). Mas o vislumbre do ser só se dá na linguagem em que o poeta o afeiçoou; o poema só existe em sua forma originária, esvaíndo-se na paráfrase explicativa. Daí ser a origem ou pátria um lugar lingüístico: na linguagem se abre a clareira do ser, a qual é por sua vez o lugar do sagrado, ou seja, do transcendente. Por dizer o divino, o poeta é profeta: vaticínio tem a ver com vate. (PAES, 1991, p. 39-41).

Numa leitura desavisada, poderíamos interpretar as referências de Fiama a Portugal, como uma poesia nacionalista; depois da leitura dessa formulação de Paes, 
estenderemos a leitura que Heidegger fez sobre "o retorno à pátria" à poética de Fiama. Antes de Heidegger, Hegel também compartilhava a ideia de que toda viagem em direção a um princípio é uma volta ao lar, é o encontro com a língua nacional. Em função disso Fiama refletiu:

E desenvolvi a própria teoria da poesia, a pouco e pouco: fui percebendo, ou antes, vendo as metáforas e as imagens dos poetas clássicos portugueses (Nobre, Cesário, Miranda, etc.) e fui, para sempre, aprendo a sua língua, o seu léxico. Dessa leitura intensa de autores portugueses recebi o que considero hoje o fundamento da poesia - a língua nacional. Sim, a língua! Isto é, as palavras, as coisas, e o coração que as vê. (...) a língua fala e vê as coisas. E dessa língua, comum e simultaneamente literária, língua não cega, língua que vê (continuamente engendrando metáforas e imagens) parti para a língua dos poemas, a língua literária. (BRANDÃO, 1991, p.2)

Voltando à questão da "fala perfeita", lembramos do poema de Wallace Stevens em que usa o termo "sentido claro das coisas":

After the leaves have fallen, we return

To a plain sense of things. It as if

We had come to the end of the imagination,

Inanimate in an inert savoir.

It is difficult even to choose the adjective

For this blank cold, this sadness without cause.

The great structure has become a minor house.

No turban walks across the lessened floors.

The greenhouse never so badly needed paint.

The chimney is fifty years old and slants to one side. 
A fantastic effort has failed, a repetition

In repetitiousness of men and flies.

Yet the absence of the imagination had

Itself to be imagined. The great pond,

The plain sense of it, without reflections, leaves,

Mud, water like dirt glass, expressing silence

Of a sort, silence of a rat come out to see,

The great pond and its waste of lilies, all this

Had to be imagined as an inevitable knowledge,

Required, as a necessary requires. ${ }^{35}$

Este poema de Wallace Stevens é da última fase do poeta. O sentido claro das coisas é em si mesmo metafórico; a univocidade da linguagem não é mais que um sonho. Kermode (1993, p.196), analisando o poema, escreveu: "Ele é parcialmente cônscio do extraordinário esforço que se exige até para imaginar, e achar uma linguagem para isso - o sentido claro das coisas, e sustentar tal linguagem pelo momento mais breve que seja: deve-se tentar, ele parece dizer, mas é impossível, esse esforço para observar o "nada que não está ali e o nada que está"”.

\footnotetext{
35 “Após a queda das folhas, retornamos/ A um sentido claro das coisas. É como se/ Tivéssemos alcançado o fim da imaginação,/ Inanimados em um savoir inerte.// É difícil até escolher o adjetivo/ Para este frio vazio, este pesar sem causa./ A grande estrutura tornou-se uma casa menor./ Nenhum turbante atravessa o exíguo piso.// A estufa nunca precisou tanto ser pintada. A chaminé tem cinqüenta anos, pende para um lado./ Um esforço fantástico falhou: uma repetição/ Na repetitividade de homens e moscas// No entanto a ausência de imaginação teve/ Ela mesma de ser imaginada. O grande tanque,/ O sentido claro dele, sem reflexos, folhas,/ Lodo, água como vidro sujo, que expressa uma sorte// De silêncio. Em que um rato sai para ver/ O grande tanque e o seu ermo de lírios, tudo isso/ Teve que ser imaginado como um saber inevitável,/ Exigido, como uma necessidade exige." (trad. de Sebastião Uchoa Leite in: KERMODE, Frank. Um Apetite de Poesia. São Paulo: EDUSP, 1993, p. 195-196).
} 
A "fala perfeita” é a voz do poeta: "O grande tanque e o seu ermo de lírios, tudo isso/ Teve que ser imaginado como um saber inevitável,/ Exigido, como uma necessidade exige." Fiama e Wallace Stevens olham também para as ruínas, enquanto Heidegger, analisando a poesia de Hölderlin, vê o poeta como um vate. Não podemos esquecer a associação feita anteriormente com a flosa e a ave do verso "Água significa ave", a flosa é o terceiro pássaro, também terceira voz, portanto é uma metáfora de deslocamento, então, perfeito porque está sempre per fazendo, em se fazendo perfeitamente.

Vale ressaltar que Fiama usa o termo fala invés de escrita, ou mesmo, poesia, como Mallarmé, ao se referir à sua produção, ou a uma teoria poética. Eduardo Lourenço esboçou um pensamento em relação a esse termo que traremos a este estudo:

A fala surge como segunda criação do já criado, não sei se no seu caso lucrecianamente sem criador, mas exigindo para o ser, ao fim de si mesma, essa segunda visão em que o poeta, sem ser o deus dela, é um interminável eco desse labirinto sonoro da natureza e a par disso o decifrador das suas mensagens, ao mesmo tempo evidentes e enigmáticas, mas todas a única fala onde nos falamos para nos falar, e em sentido mítico existirmos na plenitude dessa fala absoluta próxima do silêncio e mesmo do nada que é só outra evidência de não sermos deuses.

O que é então a poesia como fala, a mais rente à realidade que nos tem a nós conscientes de não sermos nada, ou mesmo do nada de tudo. (...). A poesia de Fiama não ficou nunca prisioneira desse nada escrito no coração da realidade como sombra da nossa fraternidade com a morte, como Antero nos descreveu. Nela a vida, a nossa, é breve, e na sua infinidade é tudo o que pode ser sendo vida. (LOURENÇO, 2011, p.8).

É uma questão fundamental na poética de Fiama, a intimidade com a realidade. O poeta dialoga com a realidade, ciente da brevidade da vida que abarca a infinidade "que pode ser sendo vida".

Faremos um cruzamento entre os poetas que associamos. Por um lado, Fiama e Hölderlin, por outro, Wallace Stevens e Fiama, que se aproximam da ideia sobre o poeta e a dificuldade em sustentar o sentido claro das coisas. 
Voltando aos versos de "Teoria da Realidade: tratando-a por tu", leremos: "Tens na inspiração do ar o $a$ total/ que une em si a boca dos poetas/ tal como, em mim, o Camões ao de Estugarda."

Estugarda é o aportuguesamento de Stuttgart, cidade próxima àquela em que Hölderlin, nasceu ${ }^{36}$, viveu, conviveu com outros poetas e intelectuais e também imortalizou num poema. Portanto, Fiama se refere a ele. Ao deslocar o nome do poeta ao lugar em que viveu, a poeta privilegia o tempo e espaço do autor e nos remete a eles. Isso nos mostra que para ela os lugares são contemplados, assim como o tempo.

Sobre o $a$ : "no $a$ vivo, a mais audível/ nascente do alfabeto, o eco"; " ao mar as lágrimas com o $a$ de sal"; "Tens na inspiração do ar o $a$ total/ que une em si a boca dos poetas"; "Agora estás rodeada/ desta língua que nasceu do $a$."; "Juncaste a praia do $a$ das palavras/ portuguesas, tu que conheces já/ o primeiro som da vida."; "Canto o coral do $a$, o som ritual."

$\mathrm{O}$ a é a primeira letra do alfabeto, é a primeira vogal, é um som inicial para os bebês, então, por associação, nesse poema, o a representa o som poético inicial. Nas primeiras estrofes, não aparece este $a$ inicial, o tu estava mudo (“Ainda estás muda", na $2^{\mathrm{a}}$. estrofe). Na $7^{\mathrm{a}}$. estrofe o $a$ é incorporado ao sujeito poético e ao tu é nesse $a$ que se unem as bocas dos poetas, no caso, Camões e Hölderlin. No sujeito poético, se unem a boca de Camões e a de Hölderlin, da mesma forma que, em relação ao tu, que decodificaremos como o tu poético, se unem as bocas dos poetas.

"Este fundou a fala já falada,/ o canto refeito, que é legado." Refere-se a Hölderlin e à sua atenção aos estudos do mundo helênico. Por exemplo, a ação narrativa de Hiperíon está ambientada na Grécia contemporânea do escritor, pelas alturas de 1770, quando da guerra russo-turca, mas era pela Grécia antiga que ele realmente se interessava; amava a Grécia com uma unção religiosa única. A lembrança dos templos em ruínas, tudo quanto restava do mundo dos deuses, punha nele um matiz de

\footnotetext{
${ }^{36}$ Friedrich Hölderlin nasceu em Lauffen-sobre-o-Neckar. A aldeia ficava, como o próprio nome diz, à margem do rio Neckar, perto de Stuttgart, pertencia ao condado de Württemberg, na região sudoeste da Alemanha conhecida por Suábia.
} 
melancolia. No prefácio da penúltima versão de Hiperíon declarou: "A Grécia foi meu primeiro amor e creio poder afirmar que será o meu último.”

"Aquele leu o já lido, dobrou/ o antigo canto clássico." Alude a Camões, ou seja, leu as epopeias clássicas, também retomou os gregos e escreveu Os Lusíadas, uma epopeia humanista.

“Mas,/ ó minha palavra muda, pensada,/ detém-te." Nesta estrofe, aparece a primeira pessoa em: "tal como, em mim, o Camões ao de Estugarda." E aqui, o sujeito poético dialoga com sua palavra que ainda é muda, só pensada. Pede calma.

O interlocutor nesse poema vai mudando. No começo do poema, o tu refere-se ao sujeito poético que ouve a flosa, que tem mãe de berço, a Natureza, que está em formação, em metamorfose e que, na segunda estrofe, continua muda. Na terceira estrofe, a flosa é o interlocutor; passa a ser a terceira fala e a primeira pessoa aparece como sujeito, enquanto que na segunda estrofe, a primeira pessoa revela-se apenas como pronome possessivo acompanhado de passos: "meus passos". Na sexta e na sétima estrofes, o tu é a realidade. A que enuncia o poema se aproxima do sujeito poético até virar seu interlocutor. $\mathrm{O}$ tu, assim como a realidade, ganha significados.

"Já falas nos poetas,/ porém, em ti, só tens o ar,/ além das tuas três palavras." $\mathrm{Tu}$, aqui se refere à palavra muda, e à palavra do poeta que se adianta e menciona os poetas que fazem parte de sua experimentação poética. Ao já desse verso se contrapõe o ainda da segunda estrofe: Ainda estás muda, mas ouves/ cantar um nome" e se une à continuação: "ouviste já/ dois nomes"- (mar e murmúrio). Enquanto na segunda estrofe, “estás muda"; nesta "falas". O ar é o mesmo de: "na inspiração do ar o $a$ total". E as três palavras são: "Flosa, mar e tu" que se transformarão em: "Flosa, mãe, mar", na nona estrofe.

"Depois/ da voz cansada, inspira o mar, repara/ nas marcas da água. Narravas." A voz está cansada, por tanto pensar e relembrar? A voz cansada "inspira o mar", inspira se relaciona à "inspiração do ar o $a$ total”. O $a$ que está em mar. Afinal "o mar foi o sinal da palavra nova, o ser da água/ das águas, similares/ no $a$ vivo, a mais audível/ nascente do alfabeto, o eco.” Repara nas marcas da água é o que fica, afinal: “o que perdura, porém, fundam os poetas". Até aqui, a autora conta uma história, a da experiência de sua voz poética. $\mathrm{O}$ tu é o sujeito travestido de poeta. 


\section{Oitava estrofe}

Quando tu me tocaste, no mar, assinalavas as tuas marcas, as palavras: águas, ó águas!

Depois das três palavras, deixaste-me falar comigo, e eu, cansada, palavra após palavra, ouvi um poeta, mais dado à realidade, a ti, ó realidade! Este era, em si, sem nunca saber do de Estugarda.

E dele, por ele, refundei a língua em que Portugal me falava: mãe tão longe já da minha fala, mãe mutilada, porque a fala-língua já não é clara, e aquelas palavras, as três de toda a realidade, agora são as estrofes dos meus versos. Minha realidade, tu não sabes como o Camões, nos seus dez cantos, te deixou presa entre dois tempos. 
Relacionamos "assinalavas as tuas marcas" com "repara nas marcas da água”, na sétima estrofe. $\mathrm{O}$ tu, aqui, se refere à realidade como toque da poesia, como sentido do tato, o que traz proximidade e concretude, deixa marcas e palavras: "águas, ó águas." O símbolo da transformação, da mutabilidade, ou, como disse Tales de Mileto (624 a.C. - 547 a.C.): "a água é o elemento primordial de todas as coisas, e que a terra flutua sobre a água." Também Nietzsche escreveu: "a água é a origem e a matriz de todas as coisas. Será mesmo necessário deter-nos nela e levá-la a sério? Sim, (...) porque nela, embora apenas em estado de crisálida, está contido o pensamento: Tudo é um." ${ }^{37}$ Água expressa também o puro e a obtenção e o restabelecimento do estado de pureza.

"Depois das três palavras, deixaste-/ -me falar comigo, e eu cansada,/ palavra após palavra, ouvi um poeta,/ mais dado à realidade,/ a ti, ó realidade!", relacionaremos essa interjeição, com: “ó águas”, e, na estrofe anterior: ó minha palavra muda”. A interjeição é um apelo, um chamamento em que a voz poética se denuncia. O sujeito poético apela para a realidade, para as águas e para a palavra muda. Há referência ao diálogo eu-tu que se instaura desde o início do poema. Depois da influência sugerida pelos poetas e principalmente por Sophia, reconhecida através da palavra mar, assinalando o lugar: "no mar", o sujeito poético não ouve mais essa fala, ouve outro poeta, "mais dado à realidade".

Outra relação que poderemos fazer entre os versos é: "e eu, cansada", com a "voz cansada", da estrofe anterior. Podemos ressaltar o advérbio de tempo depois em: "Depois da voz cansada", com o "depois das três palavras". Predomina o advérbio depois que contrapõe ao antes da primeira estrofe: "quando antes vagias"; "antes do seio". Nesse poema, não existe um agora sem outrora.

No mesmo verso, há afirmação e confirmação da primeira pessoa: “deixasteme falar comigo, e eu, cansada/" - me, comigo, eu. A comunicação foi interrompida e a voz está cansada. Ainda assim ouviu, ouviu "um poeta,/ mais dado à realidade,/ a ti, ó realidade!”. O ó é uma interjeição e como em todas as interjeições há um apelo, um

\footnotetext{
${ }^{37}$ Citado por Marise Moassab Curioni in: HÖLDERLIN, Friedrich. A Morte de Empédocles. São Paulo: Iluminuras, 2008. P.45. Curioni continua: “Hölderlin adere, de forma incontestável, à crença nos vários ciclos de vida, passando por sucessivas purificações." (2008, p. 46).
} 
chamamento, uma proximidade pela emoção e pela tentativa de diálogo, confirmando a proposta da poeta.

Então, depois de descobertas, embates, epifanias, "mar, flosa e tu", diálogo com outros poetas, tudo isso desencadeou em poesia, em "fala perfeita"; a partir da interrupção do diálogo, "deixaste-me falar comigo", a voz poética se volta metalinguísticamente para o seu próprio fazer poético.

"Este era, em si,/ sem nunca saber do de Estugarda./ E dele, por ele, refundei a língua/ em que Portugal me falava: mãe/ tão longe já da minha fala, mãe mutilada, porque a fala-língua/ já não é clara, e aquelas palavras,/ as três de toda a realidade,/ agora são as estrofes dos meus versos."

O poeta que "era, em si, sem nunca saber do de Estugarda" é Camões, e por ele, o sujeito poético refundou a língua. Fundar, no sentido que falamos acima: "Tu, realidade, és nome de ti/ e do que os poetas fundam".

Na estrofe anterior, há "o canto refeito, que é legado." Nesta estrofe, "refundei a língua". O prefixo reaparece para confirmar a recriação, a poesia nasce de outros cantos, cada poeta precisa refundar a língua. Aprendeu a língua materna e ao ler Camões refunda a língua. Já há a fala e, duas vezes, o advérbio já: “tão longe já da minha fala"; "porque a fala-língua/ já não é clara". A língua de Camões está longe da dela, porque há uma distância temporal. A língua se modifica - a mãe - "mãe-língua" e "mãe-pátria", "mãe mutilada" porque é a condição da língua. O sujeito poético assume, finalmente, as estrofes do seu verso, ainda apenas com as três palavras.

"Minha realidade, tu não sabes/ como o Camões, nos seus dez cantos,/ te deixou presa entre dois tempos." Os dois tempos: tempo das descobertas, imortalizado por Camões em Os Lusíadas, e o de hoje, da leitura de Camões e o desejo de escrita. A primeira pessoa aparece no pronome possessivo, apropria-se, assim, da realidade. Assim como Camões não sabia que Os Lusíadas seriam imortalizados, a realidade do sujeito poético também não sabe se será imortalizada.

A partir dessa estrofe, a oitava, o sujeito poético assume sua condição de autor, e com isso enfrenta a questão da autoria e das influências. George Steiner (2001, p. 31) escreveu que "o artista 're-conta'; ele estabelece o inventário do existente." 
O princípio central da tese de Harold Bloom (1991, p.62) é:

A influência poética - quando envolve dois poetas autênticos, fortes - procede sempre por uma desleitura do poeta anterior, um ato de correção criativa que é, na verdade, e necessariamente uma interpretação distorcida. A história das influências poéticas produtivas, que é a história da tradição central da poesia do Ocidente a partir da Renascença, é uma história da angústia e da caricatura autoprotetora, da distorção, do revisionismo voluntarioso e perverso, sem o que a poesia moderna, como tal, não poderia existir.

No poema de Fiama, é exposto o passado poético, até "atualizado" em "ó mar salgado,/ e quantas das águas serão/ as lágrimas de Portugal.”, na quinta estrofe, mas, nos parece que não há angústia da influência, apenas constatação. O passado poético não é um obstáculo à criação do novo.

\section{Nona estrofe}

Ouviste a flosa ser cantada,

a cantar-se. Agora estás rodeada

desta língua que nasceu do $a$.

Inspiras, expiras. Os versos

só são o que os poetas fundam.

Flosa, mãe, mar, em que versos

somente sois as palavras minhas?

Tu deste-me as palavras novas 
da tua fala escassa, calada

pelo escorrer do leite. Depois,

a língua mudou-te as dimensões,

e cada verso é uma linha tua,

em que eu te fundo. O que sou,

ao chegar a um limite da fala,

a um verso, que os poetas fundam?

Mas deixo o abstracto, a galáxia,

o cérebro e até um verso. Estou

no simples lugar do mar, velha água,

muralha a bordejar-te.

“Ouviste a flosa ser cantada,/ a cantar-se." Voz passiva, o poeta/ tu canta a flosa e ela canta a si mesma. O tu é o mesmo da estrofe inicial, o diálogo é com seu sujeito poético. Se, num primeiro momento, o tu ouve a flosa, num segundo, o sujeito poético pôs a cantar a flosa, agora a flosa canta a si mesma. A flosa volta a ser apenas a ave.

O verbo está no pretérito perfeito, ou seja, já aconteceu, o canto começou. Estamos no presente marcado pelo advérbio - agora: “Agora estás rodeada/ desta língua que nasceu do $a$." Está imersa na língua portuguesa de seu tempo, já a reconhece e conhece a origem, o $a$; assim como o $a$ está rodeado em mar, por consoantes. O poema não se reduz ao presente, a palavra criada não vem do acaso, nem de hoje.

“Os versos só são o que os poetas fundam”. Marca de uma mudança, enquanto anteriormente, a realidade é o nome do que os poetas fundam; agora os poetas inauguram só os versos, que fazem parte da realidade. O acento está na palavra só, ou 
seja, nada tão importante. Aliás, os poetas escrevem, ou fundam versos, apenas isso, sem filosofar, portanto retomam o concreto.

"Flosa, mãe, mar, em que versos/ somente sois as palavras minhas?" As três palavras do sujeito poético sofreram uma transformação. Até esse verso, as três palavras eram: "flosa, mar, tu"; aqui as três palavras são: "flosa, mãe, mar". O tu se metamorfoseou em mãe. O acento é na transformação do tu em mãe; do diálogo, representado pelo tu, à matriz, simbolizada pela mãe, também como língua.

Após viver descobertas e diálogos, quando teve ou terá sua própria voz? A voz poética pergunta ao tu: “em que versos/ somente sois palavras minhas?” É a questão da individuação, da autenticidade de suas palavras, do questionamento de se livrar das influências, mesmo sabendo-as fundamentais para a formação da sua voz poética. É a angústia da influência, comentada por Harold Bloom. É a questão de as palavras que usa - e que no idioma pertencem e são usadas por todos - assumirem uma personalidade própria, destacarem-se como da voz poética. Quando terá sua voz própria, é o que se pergunta. Camões é parafraseado e incorporado ao texto, e depois de Camões, Sophia, como voz feminina. Assume a autoria por meio de Camões e de forma mais sutil, de Sophia.

"Tu deste-me as palavras novas/ da tua fala escassa, calada/ pelo escorrer do leite. $T u$, neste verso, pode se referir à realidade. $\mathrm{O}$ escorrer do leite está relacionado à abundância: há oposição entre a escassez, por uma lado, e por outro, a abundância. O mais interessante é que a escassez está justificada pelo escorrer do leite: "da tua fala escassa, calada/ pelo escorrer do leite". O "escorrer do leite" tem a ver com a proximidade do estágio inicial da vida, o início da vida poética, e, de fato, a poesia de Fiama, inicialmente, era contida, versos curtos, poemas sintéticos, sobretudo em Morfismos, de 1961.

"Depois,/ a língua mudou-te as dimensões,/ e cada verso é uma linha tua,/ em que eu te fundo." Os versos mudam de dimensão e a poeta adquire a "fala perfeita" porque funda a realidade: "Tu, realidade, és nome de ti/ e do que os poetas fundam,/ depois de terem a fala perfeita." A poeta funda a realidade a partir das palavras. Para chegar até essas palavras foi um longo percurso. 
"O que sou,/ ao chegar a um limite da fala,/ a um verso, que os poetas fundam?" Outra pergunta se faz, em relação aos sujeitos e personae poéticos. É uma pergunta existencial, o eu existe, como poeta e como pessoa, faz parte da realidade e faz parte da poesia.

"Mas deixo o abstracto, a galáxia,/ o cérebro e até um verso." Retoma o princípio deste poema: "Ouves cantar a flosa, e erras,/ não é ela, era o mar antes criado,/ era a galáxia, o teu cérebro, aquela/ que já ouviste ao aprenderes a fala." As questões abstratas deixarão de ser exploradas e ela anuncia onde está: "Estou/ no simples lugar do mar, velha água,/ muralha a bordejar-te.” Não está no mar, mas "no simples lugar do mar”. Há uma comparação entre ela e o mar, uma comparação não perfeita porque está no lugar, não é o mar. O sujeito poético marca o lugar em que está, o espaço. Os elementos semânticos, que sugere, são próprios do ambiente marinho. A imagem é de um lugar que pode ter intempéries, quase violento, "muralha a bordejar-te". É a imagem do embate com a língua. O lugar do mar não nos parece simples, como o sujeito poético colocou, é um lugar honrado, majestoso. Bordejar-te: navegar em zigue-zague na realidade?

Assim acaba a primeira parte do poema porque a poeta anuncia que deixará o abstrato, a galáxia, o cérebro, até um verso e começa a construir um lugar, um espaço concreto, que é a praia. Já está preparada para a vida poética, tem as palavras. Criou uma intimidade com a realidade que está no lugar do mar, há uma transposição. Aos poucos nos mostrou seu aprendizado e desenvolvimento poético, ainda procurando palavras e permanecendo no abstrato.

Na segunda parte do poema, que principia, em nossa leitura, na estrofe décima, o fazer poético está relacionado ao lúdico, ao brincar, os elementos são os brinquedos de crianças na praia. Começa na décima estrofe e vai até o fím.

\section{Décima estrofe}

Pelo plano do mar correm crianças, 
como eu, na sua fala, e os barcos

estão a ser chamados por um nome.

Toda a longa costa continua

Portugal, em lágrimas de sal.

Vai alto o sol, renova-se

o real pelos meus olhos, fitos

na Graça do mar, que é derramada

sobre esta língua e os versos.

Balbuciando, assim os poetas nascem

das mulheres-braços, que os lançam

no concreto, no lúdico mar.

Plano nos remete à horizontalidade, ao espaço dimensionado por um desenho mesmo que imaginário. Há uma comparação entre o movimento do sujeito poético, ao fazer o poema, na fala, nos remete à verticalidade, e o correr das crianças pelo plano do mar, na praia. O movimento se dá pelos planos horizontais e verticais: o plano do mar, ou do papel, por um lado, e o do sujeito poético e das crianças, por outro. As crianças e a literatura nomeiam os barcos. A palavra crianças está no sentido adâmico, inaugural, tanto que nomeiam os barcos, como Adão, no Paraíso, nomeou os seres. Podemos concluir que criança é metáfora de poeta, aquele que nomeia os seres, então, os poetas escrevem sobre o mar como o sujeito poético na sua fala, na sua poesia.

No quarto e quinto versos, o sujeito poético retoma os versos "Agora/ tens de saber o que podemos ser:/ águas, lágrimas, o Portugal." (versos 70, 71 e 72, da $5^{\mathrm{a}}$. estrofe), numa relação intratextual. A questão do tempo se coloca pela palavra continua e se prolonga pela palavra longa, trazendo uma ideia de continuidade pela sonoridade da nasal e por analogia ao conteúdo dessas palavras. Por meio dessa intratextualidade 
alcançamos a intertextualidade com os poetas mencionados no poema: Pessoa de Mensagem e Camões. Na 5a . estrofe, "águas, lágrimas, o Portugal” são palavras que o sujeito poético adquiriu e se consolidaram pela tradição, aqui, essa ideia de continuidade perpetua.

Somos situados em relação ao tempo no poema: "vai alto o sol", essa imagem se completará com: “O sol brilha, nos telhados do mar", na décima segunda estrofe. É o dia que vai se esvaindo e podemos relacionar o caminhar do sol ao tempo vital do sujeito poético. O real é renovado pelos olhos do sujeito poético que está maduro e consciente, já tem a fala poética e reconhece a Graça do mar. É como se o mar proporcionasse uma Graça, o dom das palavras, na língua portuguesa. Esse dom é esparramado na língua. $\mathrm{O}$ olhar do sujeito da enunciação está fito na Graça ${ }^{38}$ do mar e o mar derrama essa Graça sobre esta língua, a portuguesa e a de seus versos.

Enquanto nos versos anteriores, temos a ideia da continuidade, aqui aparece a renovação. É o pêndulo da criação: por um lado, a tradição, por outro, a renovação. O sujeito poético renova o real pelos seus olhos que fitam a Graça do mar que é derramada sobre esta língua e os versos. O mar tanto faz parte de elemento da tradição como do elemento da renovação; assim a realidade toma uma nova forma, ou melhor, abrange mais elementos. O novo poeta amplia, dessa maneira, os versos na língua portuguesa.

Os poetas não nascem com a "fala perfeita", mas nascem balbuciando e aprendem, com a experiência, a nadar/criar, são lançados no "lúdico mar". Os poetas são lançados no concreto, por mulheres-braços. O sujeito poético nos conta como nascem os poetas. Relacionando a criação com o concreto, que é reforçado pela palavra mulheres-braços, e com o lúdico, adjetivo de mar, mais uma característica de mar. $\mathrm{O}$ real e a criação poética estão relacionados com o concreto e com o lúdico. O mar faz parte da realidade e da criação poética.

\footnotetext{
38 Dom que Deus concede aos homens e que os torna capazes de alcançar a salvação. Também é um bairro de Lisboa, onde morou Sophia de Mello Breyner Andresen.
} 


\section{Décima primeira estrofe}

Que, em jogos, seguem as pegadas

de outros, que as seguem de outros,

já tu sabes. É a terceira voz,

que te revelo agora ser a voz

de poetas, seguida marca a marca.

Juncaste a praia do $a$ das palavras

portuguesas, tu que conheces já

o primeiro som da vida.

A estrofe começa pelo pronome que, sugerindo-nos continuidade, o sujeito da oração está na estrofe anterior, são poeta(s) nascente(s). A imagem de seguir as pegadas é uma imagem para a intertextualidade, que Fiama imortalizou num verso: "Existimos sobre o anterior" (2006, p. 173). Ela aparece aqui na metáfora dos jogadores/ poetas que seguem as pegadas uns dos outros. Os poetas estão em jogos - relação entre o lúdico e a criação artística. Continuamos com a imagem da praia, com as pegadas e os passos, o tato, por associação. Fiama faz sobreposição entre uma imagem concreta: a praia e o mar e outra remota, com o tempo anterior, o passado. Essa imagem de pegadas é visual e nos transporta, através das pegadas, a um passado, a outros tempos e versos. O advérbio de tempo já é utilizado novamente, não se está mais na busca, agora se sabe. $\mathrm{O}$ interlocutor sabe, sabe o quê? Que a criação poética não nasce do nada, ou apenas da experiência daquele poeta, mas também da leitura e experiência de outros poetas anteriores.

O lúdico e o jogo estão presentes na imagem da poeta. Citamos Johan Huizinga, através de $O$ Tabuleiro Antigo, de Maria Helena Nery Garcez (1990, p. 3537- 38): 
(...) Todo jogo é capaz, a qualquer momento, de absorver inteiramente o jogador.

Reina dentro do domínio do jogo uma ordem específica e absoluta. E aqui chegamos a sua outra característica, mais positiva ainda: ele cria ordem e é ordem. Introduz na confusão da vida e na imperfeição do mundo uma perfeição temporária e limitada, exige uma ordem suprema e absoluta. (...). É talvez devido a esta afinidade profunda entre a ordem e o jogo que este, como assinalamos de passagem, parece estar em tão larga medida ligado ao domínio da estética. Há nele uma tendência para ser belo (...).

(...) reconhecer o jogo é, forçosamente, reconhecer o espírito, pois o jogo, seja qual for sua essência, não é material. Ultrapassa, mesmo no mundo animal, os limites da realidade física. Do ponto de vista da concepção determinista de um mundo regido pela ação de forças cegas, o jogo seria inteiramente supérfluo. Só se torna possível, pensável e compreensível quando a presença do espírito destrói o determinismo absoluto do cosmos. A própria existência do jogo é uma confirmação permanente da natureza supralógica da situação humana. Se os animais são capazes de brincar, é porque são alguma coisa mais do que simples seres mecânicos. Se brincamos e jogamos, e temos consciência disso, é porque somos mais do que simples seres racionais, pois o jogo é irracional.

Fizemos essas citações para pensarmos que não é aleatória a relação da criação poética com o jogo, com o lúdico, é uma relação estabelecida pela tradição literária. Por exemplo, Ricardo Reis, em “Os Jogadores de Xadrez”, associou essas duas questões, como foi apontado por Garcez, no trabalho citado.

"É a terceira voz,/ que te revelo agora ser a voz/ de poetas, seguida marca a marca." Terceiro nome, terceira fala, agora é a terceira voz, é a voz de poetas, que é seguida, "marca a marca", depois de fundarem a poesia. Como num espelho, essa estrofe reflete estrofes anteriores em que o sujeito poético já tratou das influências: terceiro nome (v.45), terceira voz (v.167) e terceira fala (v.33, v.34 e v.53). São dobras da "fala". O sujeito poético nos revela quem é a terceira voz: é a voz dos poetas fundadores de poesia, é a voz dos poetas "maiores", no vocabulário de Harold Bloom. Roland Barthes (2005 b, p.22) cita um haicai de Issa e o comenta: 
A criança que o imita

É mais maravilhosa

Do que o verdadeiro alcatraz.

Há o alcatraz, a criança e o poeta: este não imita a criança que imita, ele o diz, ele o enuncia, ele o profere: a literatura não nasce de uma imitação direta, mas da proliferação, da enunciação do mundo como movimento de Espelhos.

O sujeito poético está respondendo à questão da influência e da imitação, uma questão da poética desde Aristóteles, que já refletira e tratara acerca disso.

Colocada de outra forma, podemos entendê-la como a terceira voz, a terceira realidade - comentada por João Barrento (2000, p. 275) -, "que emerge e se insinua entre duas presenças - no encontro amoroso; na estrutura da metáfora; nas figuras do paradoxo, da antítese ou da ironia romântica; no jogo entre narrador e autor na ficção". Jorge Fernandes da Silveira (2006, p. 33) escreveu: "Fiama está entre a palavra e as coisas. É neste entrelugar, com uma maneira muito íntima de falar do intervalo, que ela deixa que se publiquem os seus poemas."

Podemos, ainda, incluir o leitor, que Fiama nomeia: “e que só deve ler-me quem não tema reconhecer-se como leitor único". (2006, p. 235); ou: "Entre todas as presenças, eu esperei/ a do leitor. Quis ver-lhe os cílios/ tremerem com a mancha poética.” (2006, p. 612). Sobre essa questão, Jorge Fernandes da Silveira se pronunciou (2006, p.33):

É através da apresentação do "leitor único" que aprendo a ler a imagem do Amor Único. A meu ver, é uma figura sem representação, ou melhor, de representação discreta na obra de Fiama, visto que, como pura imagem nascida na interlocução entre os gestos de leitura e de escrita, ela está em permanente estado de criação. O Amor Único é um bem que se conquista por meio da troca de afetos entre o escritor e o leitor. 
Como se o leitor precisasse conhecer e reconhecer a terceira voz para assim participar do encontro. O texto poético cria essa terceira voz e a escritura surge como a terceira margem, a partir da leitura do "leitor único".

A ideia de continuidade, proposta na estrofe anterior, é confirmada aqui pelo verbo seguir: "seguida marca a marca"; "seguem as pegadas/ que as seguem de outros".

"Juncaste a praia do $a$ das palavras/ portuguesas, tu que conheces já/ o primeiro som da vida." Há o interlocutor, o tu, que passou pelas experiências mencionadas anteriormente, e, nessa estrofe, já conhece o primeiro som da vida e juncou a praia de $a$, o a inicial e o da língua portuguesa. O sujeito poético retoma o $a$, que está em: "no $a$ vivo, a mais audível/ nascente do alfabeto, o eco."(v.78 e v.79); "E os meus olhos mostraram também/ ao mar as lágrimas com o $a$ de sal.”(v.80 e v.81); "Tens na inspiração do ar o $a$ total/ que une em si a boca dos poetas." (v.102 e v.103); "Agora estás rodeada/ desta língua que nasceu do $a$. ." (v.135 e v.136); "Canto o coral do $a$, o som ritual.”(v.248). Essa imagem de juncar a praia, ou seja, espalhar o $a$ inicial da criação, provoca a possibilidade da difusão da criação poética. O sujeito poético, além de adquirir a "fala perfeita", espalha a palavra criativa pela praia. O tu, agora, é um desdobramento do sujeito poético, como na primeira estrofe.

A presença do já corrobora a continuidade de um movimento que fora iniciado. No verso anterior, há o agora, portanto saímos do passado, do momento primordial e estamos no presente com a urgência do já. A praia está plena do $a$ primordial e das palavras portuguesas. Quanto ao interlocutor, o $t u$, podemos entendê-lo como a voz poética e o leitor, que já conhecem o primeiro som da vida, descrito no poema. $\mathrm{O}$ verbo juncar, na segunda pessoa, é significativo. $\mathrm{O}$ tu, ou outro, ou realidade, aquele que ouve cantar a flosa, um nome, o primeiro som da vida, fecunda a praia com o $a$ primordial. Há a ideia de espalhar, de forma aleatória e fecundante; a praia é o lugar da criação, é o lugar intermédio - acaba a terra e começa o oceano, o mar, o outro mundo. Ela é o finisterrae. 


\section{Décima segunda estrofe}

O sol brilha, nos telhados do mar,

ó meu coveiro, e uma criança,

na cova que cavou, vazou o mar.

Não eu, mas outra criança-mundo

a começar. Os baldes da infância,

as bolas, os arcos, são jogos

de palavras. Mas aqui, no chão da praia,

se eu disser a minha língua solitária,

crianças abandonam o seu riso,

crianças duvidam do jogar.

Calo-me, e toda a praia está

entre tempo e lugar, solar,

vital, grega, pujante. Vem,

e os banhos teus, realidade!

Também aqui estarás, se eu me calar,

a ver mãos moldarem o mar,

ou se algum poeta loquaz se calou

desde a idade clássica. Mas tu erras,

temente não queres sair jamais

fora da minha boca, e se aceitas 
a dos clássicos, apagas-lhes as marcas.

Realidade, tu tens o teu princípio,

estendes-te, avolumas, estás,

mas não recuas, nem que os poetas

te chamem à sua língua antiga.

Estamos no mesmo lugar: na praia, e o brilho do sol reflete na superfície do mar: "nos telhados do mar", é uma tarde luminosa. Tarde porque na estrofe anterior o sol "vai alto", continuamos num refluxo coerente, numa linha do tempo. Podemos fazer esta leitura porque "o sol brilha, nos telhados do mar" - temos uma imagem que poderia ser do amanhecer ou do crepúsculo, pelo brilho na superfície do mar; os raios estão em posição oblíqua em relação à superfície do mar. No próximo verso há uma interjeição, $o$, e depois nos surpreendemos com a menção ao coveiro, aquele que abre uma cova no cemitério, ou que promove o fim de alguma coisa. Como imagem, podemos dizer que o mar enterra o sol, no crepúsculo. Há o pronome pessoal referindo- se à primeira pessoa: meu. O sujeito poético passa a dialogar com o coveiro, o seu coveiro; logo após, surge a imagem de uma criança que cava na praia, faz buracos "inocentes". Cavou tão profundamente que o mar vazou. A criança também é a imagem do poeta, o espaço é a praia, o lúdico está presente na criança que faz uma cova. Aqui temos presente a morte, representada pelo coveiro e pelo sol que brilha obliquamente; por outro lado, a imagem da criança que sempre renova o espaço. A relação que faz entre uma criança que cava a areia até encontrar água e esses versos, "e uma criança,/ na cova que cavou, vazou o mar.”, relacionando a criança ao poeta, que cava, procura palavras na profundidade e encontra o mar, melhor, vazou o mar, ou seja, é uma imagem para visualizarmos a criação que transbordou. O mar também é representante da realidade, o poeta está concretamente próximo à realidade, a manuseia, ele exercita seu fingere ${ }^{39}$, usado por Fernando Pessoa em "O poeta é um fingidor".

\footnotetext{
39 Fingere: modelar na argila; em seguida, por extensão, "modelar" (no sentido físico e moral), "imaginar" e "representar" (daí, por exemplo, o nosso "fingir").
} 
Podemos notar a questão da obliquidade pela posição do sol. A obliquidade parece ser uma proposta da poética de Fiama. Há uma antítese entre a imagem do coveiro - morte, e a imagem da criança - vida. Nesse poema, o coveiro também é a criança que cavou a areia, ou seja, no mesmo ser, há vida e morte, por extensão, na criação, há vida e morte.

Fiama usa o pronome pessoal e a interjeição para aproximar o sujeito poético ao coveiro: "ó meu coveiro". Há relação com a morte, com transformação, com o tato, o coveiro cava, usa as mãos, o tato. E, o poeta: "as mãos derrubam arestas/ a palavra principia."

Como dissemos anteriormente, criança é a personagem de "Peregrinação e Catábase", cujos versos iniciais são: "A Criança antes de ver não soube ver/ a aurora tingir e o dia amanhecer.” Maria Teresa Dias Furtado, no prefácio de Elegias do Duíno, de Rainer Maria Rilke, relaciona a imagem da criança com a do herói:

A criança que ainda não distingue categoricamente o seu eu das coisas e o mundo interior, ilimitado, da sua fantasia da realidade exterior, está tão próxima do modo de existência "aberto" como o herói que vigorosamente quer e actua e os que morrem jovens (...) porque passam de um estado ainda próximo do das crianças, portanto ainda sem habituação ao "mundo interpretado", directamente para a morte. (FURTADO, 2002, p.25).

A imagem de criança é a possibilidade e a esperança, por um lado, e, por outro, a inocência: ainda não sabe, não conhece, não experimentou, não tem intimidade com a realidade, por não distinguir ainda seu eu das coisas, é mais aberta às descobertas, "está tão próxima do modo de existência 'aberta'". No poema, o sujeito poético se coloca também como criança em: "Não eu, mas outra criança-mundo/ a começar". O poeta carrega a criança em si, mais do que isso, o poeta é criança.

O recomeçar e o renovar estão presentes na palavra criança, confirmados por “criança-mundo/ a começar", como significado. Outra imagem que Fiama já havia colocado e reafirma é a relação entre o fazer poético e o lúdico, corroborado pelos 
elementos do mundo da criança na praia e do lúdico: "baldes, bolas, arcos" e os relaciona a "jogos/ de palavras." O fazer poético é ludo, jogo e os baldes, bolas e arcos são metáforas para os gestos do fazer poético.

"Mas aqui, no chão da praia,/ se eu disser a minha língua solitária,/ crianças abandonam o seu riso,/ crianças duvidam do jogar." A realidade empírica contrapõe-se às palavras do sujeito poético. Se a poeta disser a sua língua solitária, não há ouvidos que compartilhem essa poesia, nesse lugar. Sua voz poética causa estranhamento. O leitor único não está na multidão. É a consciência da solidão do poeta, sobretudo a partir de Charles Baudelaire.

"Calo-me, e toda a praia está/ entre tempo e lugar,/ solar, vital, grega, pujante." A praia parece mais uma imagem da poética de Sophia de Mello Breyner Andresen, solar, pujante, grega. Para sugerir essa imagem "equilibrada", "solar", apolínea, a voz poética precisa calar. A paisagem aparece como estrutura de sentido. A praia está entre tempo e lugar: em algum tempo e lugar indeterminados. $\mathrm{O}$ adjetivo grega é inesperado e traz a poesia de Sophia, ao mesmo tempo que evoca a infância da poesia ocidental.

"Vem,/ e os banhos teus, realidade!/ Também aqui estarás, se eu me calar,/ a ver mãos moldarem o mar,/ ou se algum poeta loquaz se calou/ desde a idade clássica." A realidade é clamada, se aproxima da ideia da praia, do mar. A realidade não deixará de existir se ela se calar e ficar apreciando a praia. O tato está presente em: "mãos moldarem o mar". É a concretude. Este verso é reflexo de: “As mãos derrubam arestas/ a palavra principia”, porque mar é a possibilidade de criação, podemos constatar que as mulheres-braços lançam os poetas ao lúdico mar; se a criação é lúdica e o mar é lúdico,

então o mar é potencialidade de criação. As mesmas mãos que derrubam arestas para a palavra principiar são as que moldam o mar. As mãos moldam o mar: moldar está relacionado à modelagem, ao fingere mencionado acima, à criação através das mãos, mas moldam o mar, que não tem forma, é água. Então, as mãos têm uma ação concreta e outra poética. São poemas que são feitos tomando o mar como mote. No primeiro verso, há um chamamento, um clamor pela realidade e pela renovação, representada por "banhos". A realidade estará aqui, se a poeta se calar "ou se algum poeta loquaz se calou desde a idade clássica." É uma reabilitação da realidade, porque não precisa do poeta para existir, como no poema mencionado de Hölderlin. O poeta não é um 
demiurgo, o mensageiro dos deuses. Parece que há interlocução com Camões, poeta loquaz, é uma relação entre o literário e o mítico.

"Mas tu erras,/ temente não queres sair jamais/ fora da minha boca, e se aceitas/ a dos clássicos, apagas-lhes as marcas." Erras, relacionamos com: "Ouves cantar a flosa, e erras", o primeiro verso desse poema. Como já dissemos, erras tem a conotação de enganar-se, mas também pode estar relacionada a viajar, no sentido de errância, a errante, que já foi metáfora de poeta. Assim como a flosa, uma ave errante. O interlocutor, o tu percorre os caminhos do poema. O poema de Fiama sugere movimento. O tu, aqui, pode ser a realidade como matéria poética, tem medo de ser cantada, aceita os cantos clássicos, porém apaga-lhes as marcas. A imagem que permanece é a da praia e a das pegadas que ficam e se apagam, é uma imagem para a intertextualidade, deixam e apagam marcas. Fiama escreve sobre o presente, apesar de toda a história, o passado, as heranças.

"Realidade, tu tens o teu princípio,/ estendes-te, avolumas, estás,/ mas não recuas, nem que os poetas/ te chamem à sua língua antiga." Os princípios da realidade estão relacionados aqui à poesia. Os poemas e a realidade se estendem, avolumam-se, estão, são as diversas poéticas que, ao longo da história, existem, perduram ou mudam.

\section{Décima terceira estrofe}

Sim, os clássicos chamaram-te, e eu

li que antes da voz dos clássicos,

a Via Láctea, ninho de galáxias,

o Cosmos, o Caos, estiveram mudos.

Falaram-te os poetas gregos, poetas lidos. 
Ler faz embater a fala nas palavras

que são ouvidas no ouvido.

Ouves palavra-eco que vêm

para mim de novo, se essas

crianças repetirem crianças.

Elas levam o balde cheio de água

para encher a maré, levantam

a barbacã de areia, seguindo o plano

dado pela voz de alguém do meu início

ou de um livro de páginas abertas

rente ao mar. Por vezes, tu,

realidade, és um livro, aberto

numa página com o mar.

E a pura mãe folheia-te?

É uma continuação de um diálogo. Antes que os poetas clássicos, os gregos, escrevessem, não sabíamos da via Láctea, nem do Cosmos, nem do Caos, nem existíamos. Os poetas clássicos deram voz ao Cosmos, ao Caos e à via Láctea; escreveram sobre a realidade, chamaram-na, ou seja, buscaram representá-la. Poetas gregos canonizados são referências para nós, são os "fundadores" da nossa cultura ocidental. Notamos que as imagens da primeira estrofe, mar, galáxias, cérebro, depois Cosmos se repetem aqui. A estrofe começa com uma resposta afirmativa a uma suposta pergunta sobre a questão da poética clássica, a segunda pessoa refere-se à realidade: "os clássicos chamaram-te". Antes de serem cantadas, a Via Láctea, o Cosmos e o Caos não se pronunciavam, ou seja, o sujeito poético anuncia que a voz dos poetas é fundamental para a realidade existir para aquele que lê, ao menos a realidade mais distante, em 
relação ao tempo e ao espaço. Os poetas gregos escreveram sobre a realidade, criaram os mitos e fazem parte do legado literário e do "livro arbítrio" do sujeito poético.

O verbo "embater" chama a atenção; é uma descrição contundente do ato de ler, é ativo; o sujeito poético descreve o processo da leitura, as palavras levantam-se das páginas e passam a ser ouvidas. $\mathrm{O}$ ato de ler impulsiona as palavras por meio da fala, “que são ouvidas no ouvido", esse processo, mesmo que silencioso, reverbera um movimento intenso. Outra palavra que chama atenção nesses versos é "palavras-eco". O movimento surgido a partir da leitura se estende às crianças presentes. Se recorrermos à analogia entre criança e poeta, é a repetição que os poetas fazem dos poetas que trazem ritmo ao poema. A questão da extensão do tempo está aqui: o movimento surge no tempo, através da leitura. Portanto, seguindo o raciocínio, a leitura dos clássicos chega até o tempo da poeta e ao nosso, que retomamos a leitura. Em relação ao espaço, percorremos desde a Antiguidade até o espaço presente no poema e o encontro se dá na praia, com as crianças brincando. O sujeito poético se situa: "Estou/ no simples lugar do mar, velha água, muralha a bordejar-te." E o eco reverbera: "crianças, crianças", é a imagem do eco, que é também o movimento da leitura. A imagem do eco é a da repetição e da permanência de algo antigo, que já aconteceu e as marcas do ritmo do poema.

Então, além da leitura, as crianças/ poetas e seus sons criam a possibilidade poética. Por um lado, a poesia lida - a cultura literária, e por outro, a realidade e os ritmos presenciados pelas crianças/ poetas, a intimidade com as palavras e os sons.

"Elas levam o balde cheio de água/ para encher a maré, levantam/ a barbacã de areia, seguindo o plano/ dado pela voz de alguém do meu início/ ou de um livro de páginas abertas rente ao mar." Estamos na mesma cena, o litoral; lembrando que o litoral é um lugar de transição entre a terra e o oceano: há movimento de ir e vir. O plano é a linha do litoral, a que margeia a areia, é o "plano do mar" onde correm crianças, é o "plano/ dado pela voz de alguém do meu início", pode ser plano no sentido de projeto. As personagens são as crianças que brincam na areia, fazendo muralhas de areia e poços; seguem a tradição passada pela experiência e pela leitura. O brincar é a criação poética, a realidade representa matéria poética, ou o movimento que fazem: "Elas levam o balde cheio de água para encher a maré" - elas levam o balde e enchem a 
maré. Marca um ato ancestral e é a imagem da realidade inflando, crescendo. Ao mesmo tempo, temos a questão da presença do passado, marcado "pela voz de alguém do meu início" e que chega ao presente. Barbacã ou muro, muralha é recorrente na poética de Fiama. Neste poema podemos ler: "muralha a bordejar-te" e "levantam/ a barbacã de areia"; mostra uma separação, uma divisão. Há uma tensão (com/contra) aqui entre a voz poética e a escrita. "Elas levam o balde cheio de água/ para encher a maré”. Santo Agostinho, às avessas, no limite entre o literal e o litoral, ou o literário no limite entre o biográfico e o bibliográfico.

"Por vezes, tu,/ realidade, és um livro, aberto/ numa página com o mar./ E a pura mãe folheia-te?" A realidade é um livro aberto, onde todos podem ler, ou quem quiser ler pode fazê-lo. Está aberto aleatoriamente, "numa página com o mar". A pura mãe pode ser a língua mátria ou a criação poética. $\mathrm{O}$ ato de folhear traz a questão do aleatório. A realidade existe, é um livro aberto, ou seja, é só olhar e o livro está aberto numa página com o mar. O mar está presente, afinal o mar proporciona a graça da criação poética. É uma cena onde há movimento entre as páginas abertas de um livro e a pura mãe que folheia o livro/realidade. Mostra-nos uma intimidade entre a pura mãe, o livro folheado, a praia e nós, leitores, que espiamos essa cena.

\section{Décima quarta estrofe}

Falemos mais dos gregos,

que amaram o mar com a boca

do canto dos aedos e da escrita,

e com os barcos, que apontavam

pelas linhas dos códices, na singradura.

Ó realidade homérica, tu és

pelos tempos traída, pelas línguas, 
e eu, que medeei da fala para a leitura,

eu leio as epopeias para ti.

Se fosse tu, digo-te, a primeira

após a fala, e a palavra de poeta

seguida pelos poetas, seguidora

de todos, quero louvar-te a ti. Sabes

o que é canto, tu? A medida contada?

A harmonia flui do meu ouvido,

o falado pela ordem das sílabas,

as pausas, vogais entoadas. Som,

palavra dada, do abstracto ao tacto

do meu ouvido. Manhã, infância

em que a mãe de luz embala

as palavras no canto. Afinal,

mãe tripla, a do leite, a da fala,

a do número. Eu, depois desses poetas,

sei, tu não, que recupero

a perda da nascente da tua água,

a mina da voz, soterrada.

Calada mãe, geraste tudo o que é

ambíguo. Este falar, ouvir, ler, cantar,

tu não no-los deste, sou eu 
o artífice deste mar espraiado,

da praia que contorna Portugal.

Canto o coral do $a$, o som ritual.

Os gregos amaram o mar e o cantaram. A cultura grega se construiu pelo mar. O poeta, agora, é Homero. A palavra singradura mostra a relação com o tempo e com a viagem marítima, duas marcas da poesia grega. A realidade muda, pelo passar dos tempos e pelas traduções e mudanças de sentido na língua.

Através de Homero e das leituras dos gregos, o sujeito poético passa a meditar no Cosmos, também como matéria poética.

O diálogo continua, há um novo chamamento: "Ó realidade homérica", relaciona-se a: "ó mar salgado"; “ó minha palavra muda”; “ó águas!”; “ó realidade”; “ó meu coveiro". Nesta estrofe, o diálogo se estabelece com a realidade homérica.

Questiona a realidade sobre o que é canto e o que é medida contada. A realidade não sabe o que é medida contada, o sujeito poético sabe. A realidade existe sem saber que existe.

"A harmonia flui do meu ouvido,/ o falado pela ordem das sílabas,/ as pausas, vogais entoadas. Som,/ palavra dada, do abstracto ao tacto/ do meu ouvido." São os poemas escutados, as epopeias, o sujeito poético percebe a harmonia dos poemas, o quanto foram importantes na sua formação e como é preciso conhecer os sons e os ritmos das palavras para escrever poemas. Depois do longo percurso de aprender a falar as palavras poéticas, o sujeito poético se depara com a importância do ritmo das palavras. Enquanto na estrofe anterior, o ato de ler não tem sujeito, "Ler faz embater a fala nas palavras/ que são ouvidas no ouvido", mas se percebe o som, aqui, há o sujeito poético que lê e percebe a harmonia dos sons, "eu leio as epopeias para ti. (...) A harmonia flui do meu ouvido".

"Manhã, infância/ em que a mãe de luz embala/ as palavras no canto. Afinal,/ mãe tripla, a do leite, a da fala,/ a do número." Retoma a expressão "mãe de luz", anteriormente: "da tua mãe equívoca, mulher/ e voz, mulher e luz, seio". Retoma as 
primeiras impressões poéticas, nas palavras que remetem ao primordial: manhã, infância, mãe. E acrescenta a mãe do número, a da medida contada.

"Eu, depois desses poetas,/ sei, tu não, que recupero/ a perda da nascente da tua água,/ a mina da voz, soterrada." O sujeito poético recupera a matéria a ser poetizada, "a mina da voz soterrada", o lugar de onde flui a criação poética.

Reivindica para si a criação poética. Não é a realidade, nem a mãe (nenhuma das três) que dará ao sujeito poético o falar, ouvir, ler, cantar; será ele, o sujeito poético, agora poeta quem cantará, por sua vez, o mar, a praia, Portugal. O poeta é que é o artífice do canto.

“Canto o coral do $a$, o som ritual.” Coral é uma palavra ambígua, como o que a mãe gera. Pode ser conjunto de muitas vozes, pode ser arrecifes, pode ser a secreção desses animais aquáticos usada para fazer joias e ainda é o título do livro de Sophia de Mello Breyner Andresen, que despertou “o sentido" para a poesia, na infância de Fiama. Numa única palavra, Fiama usa um amálgama de significados, polissemia própria da poesia. Já o ressaltamos desde a primeira estrofe. É o ritual da poesia, que começou no $a$, desde o verso inicial “Água significa ave”, onde $a$ inicial também está presente.

\section{Décima quinta estrofe}

O mar global é como o ar, dá-se a ver na amplidão.

Dela recebe a fala com a voz, as palavras, altas, irreais.

Mas não me oiças negar-te, realidade do mar, palavra minha.

Criança, a tua mão de areia construiu a praia. Os teus dedos sonoros chamam-me agora. 
Chamei-te, outrora, eu, no transe

do som a pousar no meu mar.

Aceita a água que vem

para os teus pés, recebe a luz, colhe

as pequenas algas. São-te dadas

pelo passado tempo, ainda

recordado, em ti, por mim, realidade.

As imagens são ligadas à marinha. O espaço se amplia, o sujeito da enunciação recebe a fala e as palavras. A poeta conquistou a palavra, a realidade do mar e o mar são palavras de Fiama. O sujeito poético não vai negar nenhum poema dele. O poeta/ criança construiu o poema. A realidade chama a poeta, ela conquistou a palavra poética e a oferece à realidade e a nós, leitores. Recebemos seu poema como a água chega-nos na beira do mar e colheremos as algas. Nesse gesto transparece delicadeza e silêncio.

Essa estrofe é uma síntese do poema. O mar que aparece em quase todas as estrofes, aqui está caracterizado como global. É o lugar onde o poema está imerso, é a paisagem do poema, e ao mesmo tempo, é como o ar, que está em todos os lugares, está em tudo que tem vida. Se retomarmos a questão da realidade, que nomeia o poema, e sabendo que o mar também é realidade, percebemos a intensidade e a proximidade dessa imagem para Fiama. O sujeito poético, o tu com todas suas conotações e o leitor estão mergulhados e imersos na realidade. A imagem de mar, reforçada por global, comparada e igualada ao ar é a totalidade, no sentido empírico, não como completude; ou seja, tanto em profundidade - do mar, como em altitude - do ar, estamos imersos na realidade, encastoados pela realidade. Somos a realidade. Dessa situação, ou consciência, é que existe o poema, que também é realidade.

O verbo ouvir aparece ao longo do poema inteiro. "Não me oiças negar-te,/ realidade do mar, palavra minha." O sujeito poético não negará nem as primeiras palavras suas, nem a realidade, nem o mar como realidade. 
O tato está conotado em "a tua mão de areia/ construiu a praia" e "os teus dedos/ sonoros chamam-me agora." A imagem da criança, que lemos como poeta continua nessa estrofe, com o acréscimo de outra questão fundamental para esse poema: o uso dos pronomes, o eu e o tu; assim como a realidade, que se amplia até ser o todo, o eu e o tu também são ampliados e estão em movimento no poema inteiro.

$\mathrm{O}$ tu, o interlocutor presente no poema inteiro, vai se transformando e adquirindo possibilidades, sendo nomeado. O poema é um diálogo explícito, primeiro entre uma voz poética e um sujeito poético, ou seja, há um diálogo da voz poética com o sujeito poético, o tu, inicialmente é o receptor que ainda não é poeta, que ainda não fala, portanto ainda não é um sujeito. Há um desdobramento do eu poético, que persegue sua voz poética desde o início, desde seus balbucios. Depois, o tu refere-se à realidade, à realidade homérica, realidade do mar, ao leitor, ao sujeito poético, ao poeta. ${ }^{40}$

Nessa estrofe há: "Mas não me oiças negar-te,/ realidade do mar, palavra minha."; "Os teus dedos/ sonoros chamam-me agora."; "Chamei-te, outrora, eu, no transe/ do som a pousar no meu mar./ Aceita a água que vem/ para os teus pés, recebe a luz, colhe/ as pequenas algas. São-te dadas/ pelo passado tempo, ainda/ recordado, em ti, por mim, realidade." O eu e o tu se confundem, se entrelaçam, se duplicam e multiplicam. A realidade incha e engloba inclusive o sujeito poético.

O verbo chamar que marca o diálogo se faz presente ao longo do poema e nessa última estrofe, além de vários "chamamentos" ao longo do poema: "ó minha palavra muda” (v.109); “águas, ó águas!” (v.117); “ó meu coveiro” (v.174); “ó realidade homérica”(v.222). É o poema de um sujeito que insiste em ser um sujeito de percepção, torna-se um diálogo, muitas vezes um diálogo desesperado, como disse Paul Celan, em palavras citadas anteriormente.

Há contraposição temporal entre: "chamam-me agora" e "Chamei-te outrora". O sujeito poético chamou a criança para habitar o poema, na décima estrofe. Agora os dedos sonoros da criança/ poeta a chamam, os dedos sonoros também são da realidade

\footnotetext{
${ }^{40}$ Caberia uma retomada das palavras citadas neste trabalho de Paul Celan, em seu discurso.
} 
do mar. A poeta, além de conquistar a palavra poética, conquistou a realidade: "a pousar no meu mar". E a poeta chama a realidade, em mão dupla.

Os versos "Aceita a água que vem/ para os teus pés, recebe a luz, colhe/ as pequenas algas." são espelhamentos de "A primeira palavra já a dizes,/ encastoada na substância do mar,/ agora que puseram o mar todo/ a teus pés, e ao dizer-te a palavra,/ alguém a poisou e ao mar/ debaixo de meus passos." (v. 25 a v.30). e "Tão de repente,/ realidade, tu poisaste o teu pé/ nas pegadas do mar"(v.93 a v.95). Nos versos dessa última estrofe, aparecem verbos no modo imperativo, o sujeito poético está incisivo no pedido de aceitação. O interlocutor é a realidade; a alteridade do poeta que se inicia na arte poética; o leitor. É outra cena, silenciosa, introspectiva. A imagem é a do mar que vem até a praia e molha os pés das crianças.

O sujeito poético pede que a realidade aceite a água que vem para os pés, recebe a luz e colhe as algas. É um oferecimento, um pedido de aceitação, de redenção. Conclui: As algas são "dadas pelo passado tempo", retoma o advérbio ainda, recordado. O tempo é passado e é recordado pelo sujeito poético, "em ti, realidade". Fiama oferece a preciosidade da palavra poética adquirida. Podemos retomar o soneto de Camões: "Transforma-se o amador na cousa amada/ (...)/ O vivo e puro amor de que sou feito/ como a matéria simples busca a forma." Se pensarmos a "cousa amada" como a palavra poética e o amador como o poeta e a matéria simples é a palavra que busca a forma poética, a poesia. Assim, percebemos uma relação intrínseca nesses poetas, uma intertextualidade profunda. Conferindo ainda com Camões o sentido de tensão (com/ contra) do literário ( o poético) entre o mítico e o histórico, a terceira fala.

Fiama não reduz a realidade ao presente, a realidade é tempo, e por isso é possível ter tanta intimidade com ela; ela está ou é em nós assim que a pronunciamos. E a palavra que cria não vem do acaso, nem de hoje, ela é flosa e mar, lágrimas e sal, partidas e chegadas. Não existe um agora sem outrora. Fiama usa agora, outrora, mas não usa o sempre. A eternidade está fora do humano. "No princípio era o Verbo" e por ele as coisas foram criadas, isto é, o Tempo, o Real humano, pela palavra, começo e fim, vida e morte. 


\section{Conclusão}

O movimento é a única realidade essencial

Fiama Hasse Pais Brandão

Agora que não há mais

aproximação nem distância,

os alegres cacarejos ao meio-

- dia outrora,

antes do primeiro verso

voltam no fim do ciclo

para o regresso de mim mesma.

Fiama Hasse Pais Brandão 
Os primeiros contatos com a poesia de Fiama Hasse Pais Brandão foram de estranhamento. Havia um movimento, as palavras criavam algo movente, que se deslocava o tempo todo, sendo impossível abarcá-las.

Foi preciso desfocar as imagens e as palavras, fazê-las abrangerem significados sugeridos para adentrar nessa poesia.

Esse movimento tem uma intensidade, tanto vertical como horizontal, isto é, as palavras traçam um espaço entre o presente e o passado, dirigindo-se ao futuro e, por outro lado, as palavras ampliam os significados convencionais, quebram qualquer expectativa predefinida, o que causa surpresa porque o seu leitor sabe que a matéria poética de Fiama é o real, o que pertence à terra, o presente, de onde tira suas palavras e cenas. Por um lado, quebra a expectativa de signos preestabelecidos, por outro, trabalha com signos bem conhecidos, sua matéria poética é a realidade.

Se começarmos nossa leitura da obra de Fiama pelos últimos livros, por exemplo, pelos poemas de Cenas Vivas, é possível nem nos apercebermos do movimento intenso que esses versos nos provocam. Parecem poemas tão singelos, com temas cotidianos, com cenas bucólicas, das quais cada um de nós tem alguma referência. Podemos nos perguntar, então por que esses poemas nos afligem tanto? Pelo movimento que propõem, pelos desarranjos, pelo movimento interno do poema, um abranger de espaços e tempos. As palavras refletem-se uma nas outras até "parecer que já não têm cor própria e são apenas transições de uma gama", como disse Mallarmé, citado por Blanchot (1984, p.236).

Luís Miguel Nava escreveu sobre Área Branca, um juízo que aplicaremos também para Obra Breve - poesia reunida, de Fiama: "A multiplicidade de planos que nesta obra se interceptam e confundem não é de molde a encorajar a sua travessia: levála a cabo implica pôr em causa a própria identidade." (NAVA, 2004, p.219). Por isso a resistência inicial, ao mesmo tempo em que a leitura passa a ser instigante.

A poeta dá continuidade ao primeiro verso, expande sua obra e a torna Obra Breve: "os pequenos livros de meus poemas reúnem-se de uma forma contígua - tal como foram vividos (...). Na verdade, cada livro tinha sido apenas um corte - a poesia vai sendo escrita, transformada, recordada, ao correr do tempo todo." (BRANDÃO, 2006, p.12). 
Depois de muitas releituras e de fazermos múltiplas relações, adentramos no universo de Fiama, os poemas se tornaram muito vivos, se transformaram cada um deles em cenas vivas. A matéria poética se fazendo carne; por isso houve até sensação de enjoo. Foi a questão do foco, precisamos aumentar esse foco, aliás, desfocar as imagens que pululam em Obra Breve. Em seus livros cada poema é uma releitura de sua obra, e de outros autores, ao mesmo tempo em que apresenta uma versão particular, inovadora e mutante, de cada palavra, de cada verso, de cada espaço, de cada tempo, ou poema. 
Anexos 


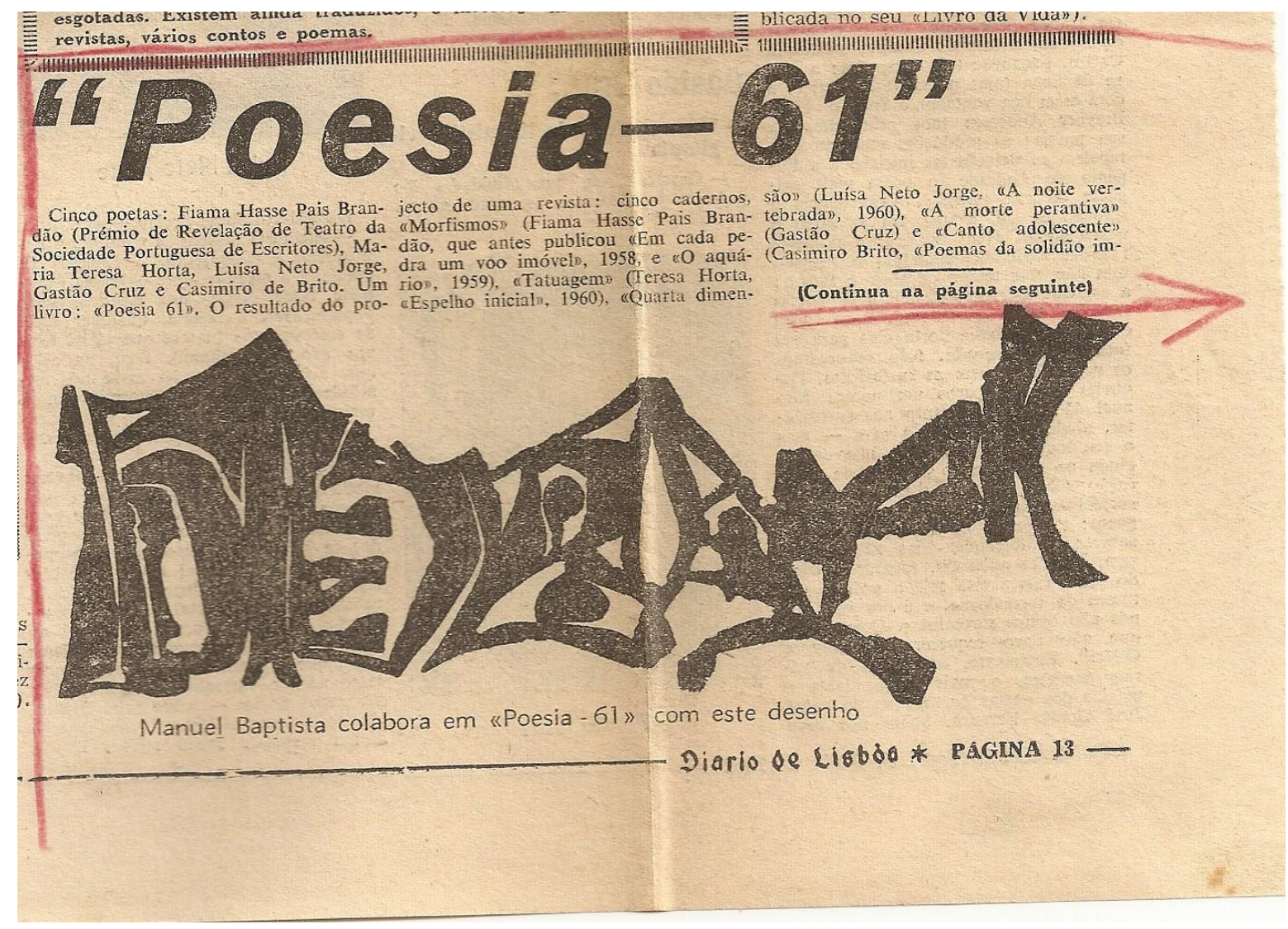

Figura 1 - Entrevista dos autores de "Poesia 61" para o Diário de Lisboa, 25 de maio de 1961 


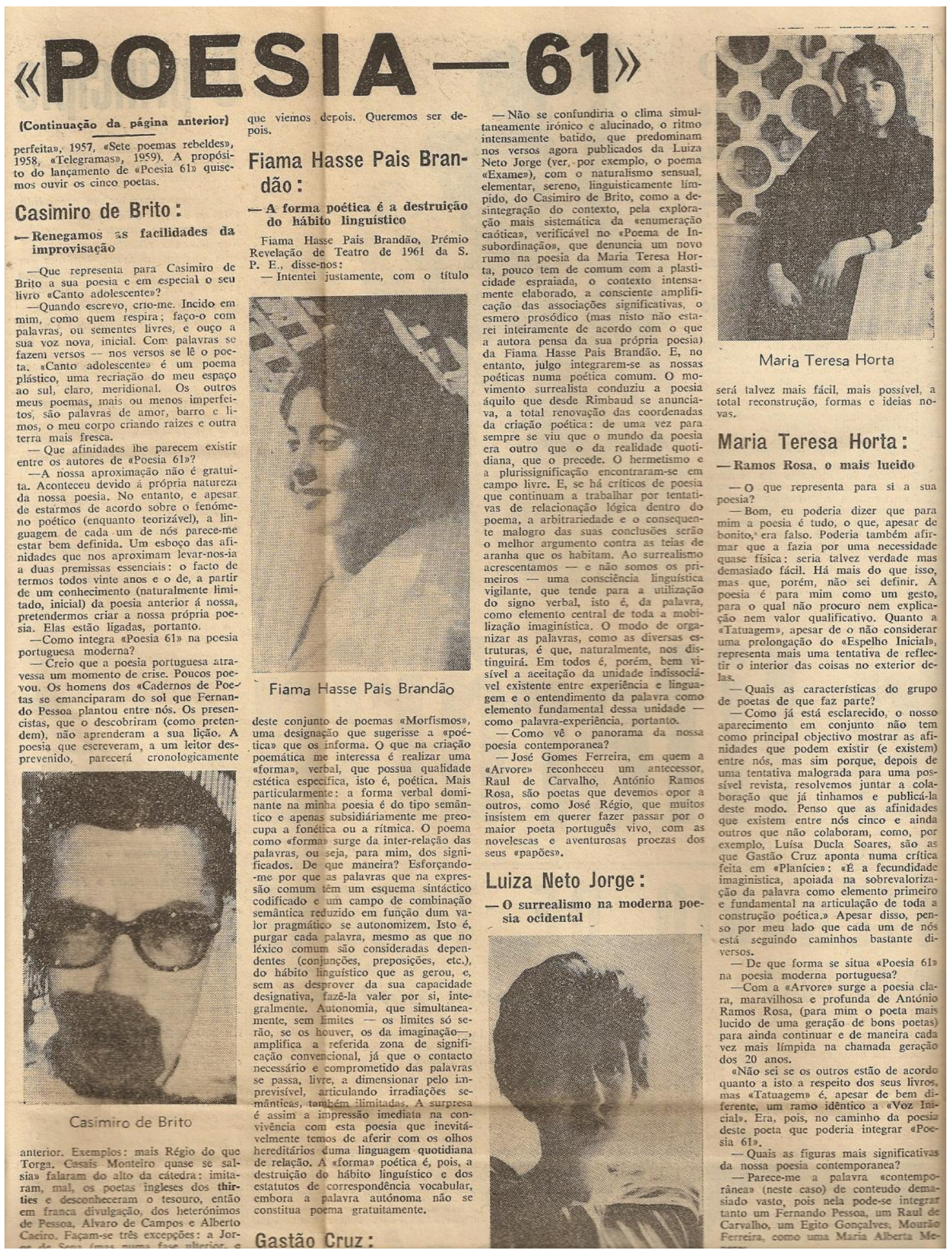

Figura 2 - Entrevista dos autores de "Poesia 61" para o Diário de Lisboa, 25 de maio de 1961 


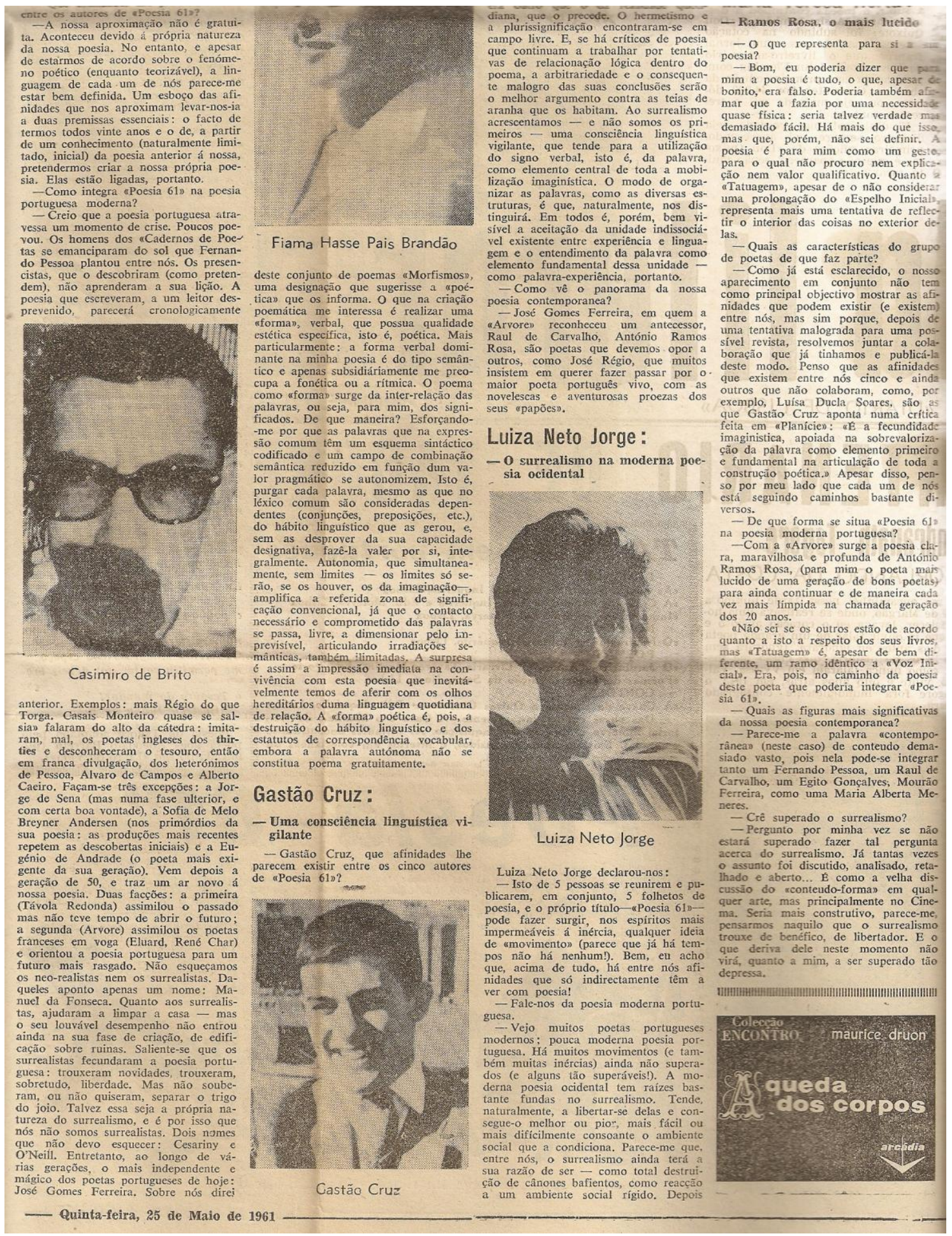

Figura 3 - Entrevista dos autores de "Poesia 61" para o Diário de Lisboa, 25 de maio de 1961 
Prefácio de Homenagemàliteratura - de Fiama Hasse Pais Brandão

Reconsiderar:

1.a consciência do sujeito social psíquico

2. a primeira pessoa narrativa

3. a narração linear para a máxima leitura unívoca

4. o aprofundamento da personagem literária ou simbólica,

5. a absoluta unicidade do Autor,

6. a absoluta necessidade do Autor,

7. o total esoterismo de cada autor no reino dos indivíduos,

8. a textualidade fechada e oculta.

9. Isto é, uma obra tão unívoca que seja maximamente opaca,

10. isto é, uma obra tão opaca que rejeite leituras.

11. ou seja: que coloque a crítica ao seu serviço,

12. sendo a crítica um privilégio e não uma missão pública, sequer universitária,

13. tendo abandonado os modernos propósitos prosélitos de postular uma obra aberta

14. para as massas de leitores da cultura de massas

15. ou democrática.

16. Levando a crítica a desistir de proclamar a abertura da obra

17. no inconfessado intuito político de rasurar a unicidade

18. texto - Autor

19. de modo a beneficiar as massas com uma leitura por leitor

20. e cumprir assim os programas políticos que desde o séc. XIX

Figura 4 - Prefácio de Homenagemàliteratura de Fiama Hasse Pais Brandão, 1976 
21. confundiram a contagem por cabeça económica com a consciência e a expressão da unicidade

22. do indivíduo, não só no plano da moral social

23. como no plano único da própria linguagem num sentido lato

24. dos seres naturais individuados

25. designados por humanos, que, podendo comummente

26. usufruir das diferenças das suas sínteses ou conglomerados históricos per capita

27. foram no entanto induzidos a acreditar

28. que a comunidade só pode disfrutar de obras com alto coeficiente de apropriação comum.

29. Assim perante a resistência psíquica e política das também modernas estruturas herméticas

30. que relevaram de um alto propósito de individuação simbólica, sobretudo na zona da mítica sensorial e, nesta, sobretudo na série ou teoria da mítica Visual,

31. os estudos pagaram à moral política o seu jus

32. concedendo à obra o estatuto de autónoma em relação a si própria

33. sendo de cada leitor a sua leitura e tendo, post scripta, a obra intenção omissa.

34. A leitura tal como outro objecto social seria multiplicável

35. e reproduzir-se-ia.

36. Mas nada impede, no entanto, a não ser a vigilância ou poder político, que os objectos sociais voltem a ser únicos.

37. mesmo antes de chegada a fase da abundância.

38. Também antes de chegados à fase antropológica da abundância de indivíduos 39. fortemente individuados pelo seu aprofundamento da história em todos os sectores do conhecimento - míticas e técnicas - ,

Figura 5 - Prefácio de Homenagemàliteratura de Fiama Hasse Pais Brandão, 1976 
40. ou seja peças únicas de uma cultura popular que seja

41. aliás tal como esta sempre tem sido na sua tradição de séculos,

42. maximamente diferenciada, esotérica, extremamente concentrada

43. no seu índice (baixo, no passado) de síntese histórica,

44. nada deve impedir que se conheça, até lá, nas obras já individuadas,

45. em que o processo histórico não se retardou,

46. se legitimamente considerarmos o seu realizado tempo histórico como o tempo possível do processo histórico

47. retardado para os grupos sociais por todo e qualquer poder político -

48. nada deve, pois, impedir que se conheça a implícita coesão hermética

49. que nelas existe pela síntese pessoal do pensamento e das práticas históricas chamada Autor.

Prefácio à Homenagemàliteratura de Fiama Hasse Pais Brandão

Editora Limiar, Porto, 1976.

Figura 6 - Prefácio de Homenagemàliteratura de Fiama Hasse Pais Brandão, 1976 


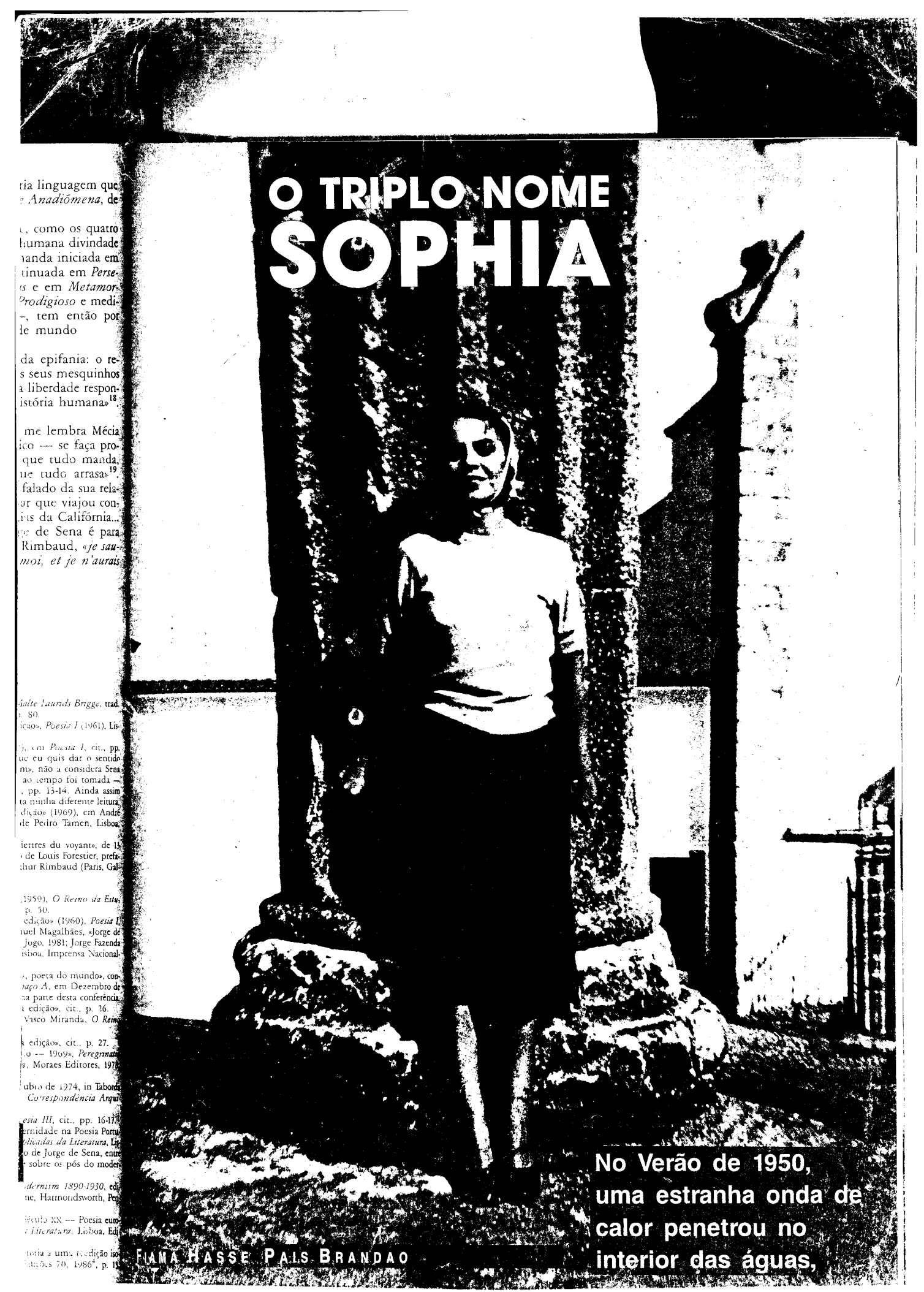

Figura 7 - A Phala - Um Século de Poesia, 1988 


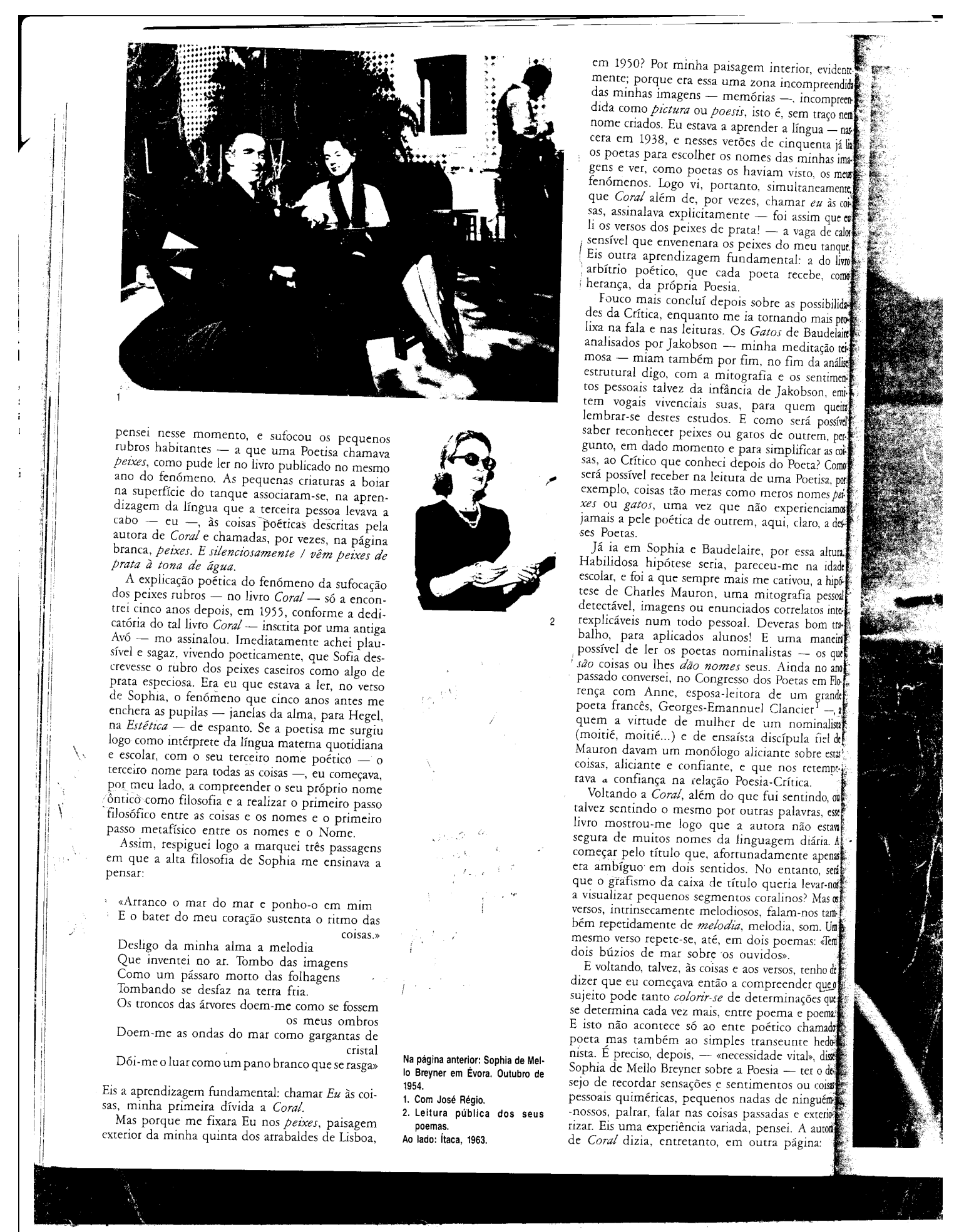

Figura 8 - A Phala - Um Século de Poesia, 1988 


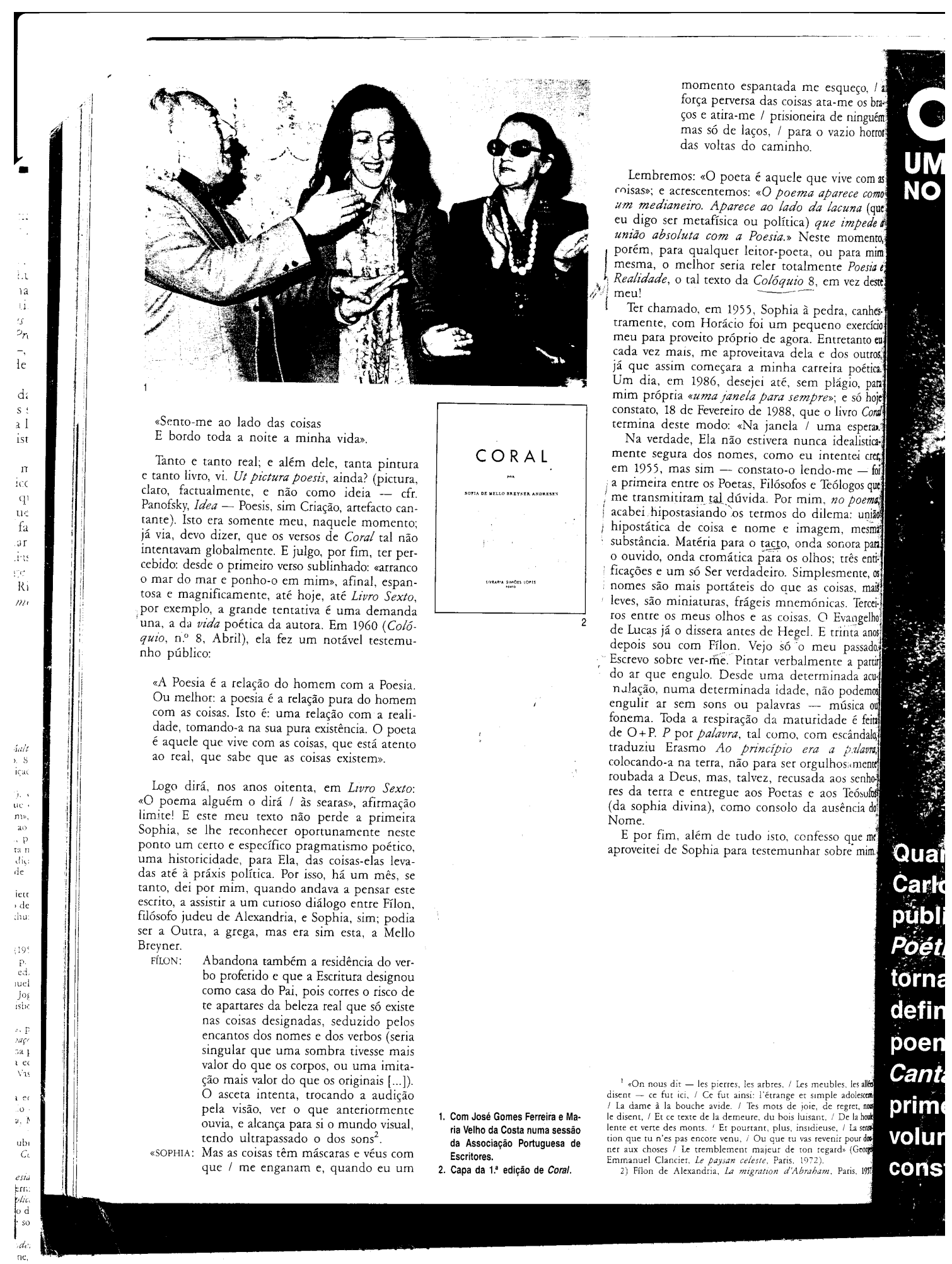

Figura 9 - A Phala - Um Século de Poesia, 1988 


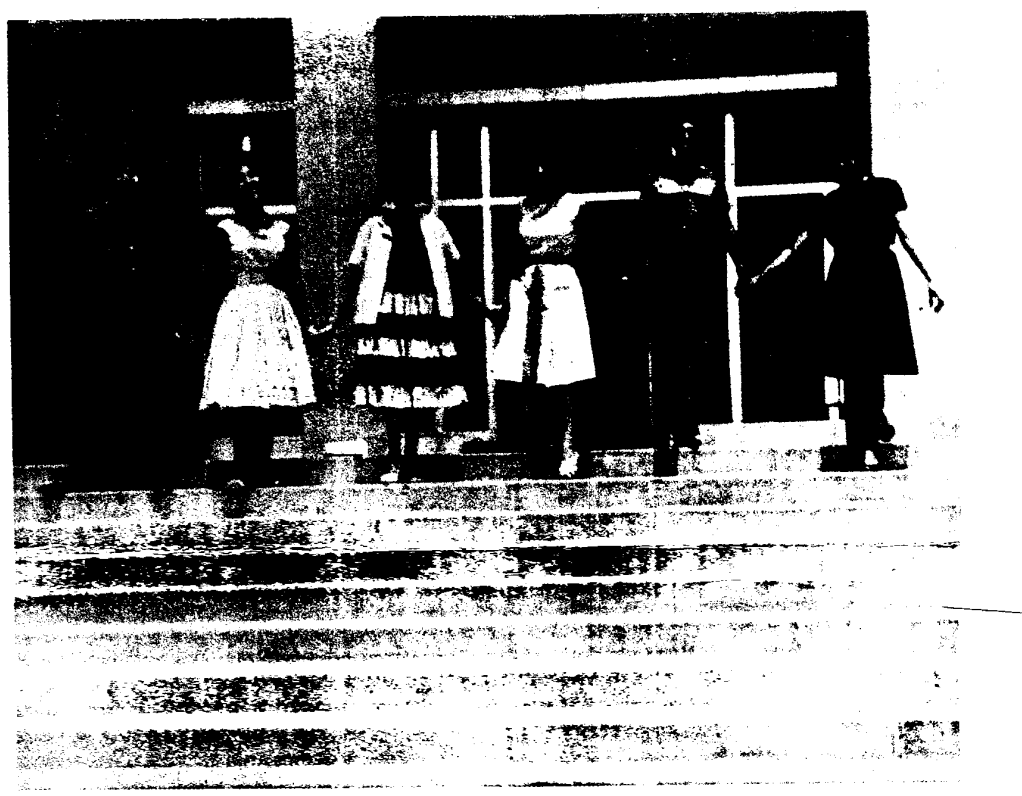

GASTAO CRUZ, FIAMA, LIZA NETO JORGE, LUISA DUCLA SOARES, FERNÃO PERESTRELO E DULCE POMBEIRO. LISBOA 1959.

\section{TRESS ROSTOS \\ FIAMA HASSE PAIS BRANDÃO}

Três livros num só mostram-nos uma mesma-nova Fiama. Três perguntas lhe fizemos. Seguem-se as três respostas dadas por quem andou no patamar da Poesia 61 .

- Quase trinta anos depois poder-se-á falar de Poesia 61 como um movimento, um grupo, reunido pelas circunstâncias político-culturais e mesmo universitó rias, uma simultânea e imediata opção estética, uma autoproclamação? Que raizes e ramos chamarias para melhor inserção da Poesia 61 na poesia portuguesa?

- Bastante poeira universitária nos olhos, sim, mas não foi isso que nos aproximou. A Teresa e o Casimiro não vinhem de circuitos universitários, por exemp. Sobretudo estava enta la em baixo, no plo. Sobretudo Algarves, a sombra para todos tutelar do grande autodidacta poético Ramos Rosa. Tínhamos uma enorme euforia e apetência pelas férias algarvias, poético-musicais, na ilha de Faro, de água verde e azul claríssima na ponta que está livre da terra - a todos nos banhava. Também ć em Lisbo procurávamos mar - uma vez às seis da madrugada, no raiar do crepúsculo matinal, fomos todos para o alto da Boa Viagem ler em voz alta, olhando a barra, a "Ode Marítiman, em 60 , creio, comovidíssimos.

Quanto a outras circunsta cialides, já dej e não dei já dei e não dei azão a Gaspar Simoes numa entreista que peço que leiam, em 86, Maio julgo, no Semanario. Não gosto de falar de poesia e de literatura, muito menos repetir. Estávamos datados: queriamos fazer algo contra os poetas retóricos sociais post-Novo Cancioneiro e contra os retóricos vivenciais post-Presença. E liamos mal Mallarmé, etc., etc. Já tentei trazer à mesa esta meia mea culpa. E creio que qualquer de nós, no livros subsequentes, na década de sessenta, se «relancous de novo, cada um no seu caminho novamente intencional e inicial. Eu, em Barcas Novas, repeguei um certo lirismo cadenciado, que vinha fazendo, pus na praça o eu (que algum de nós omitira em 61

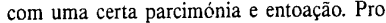
pus toadas de teor histórico e pequenas impressões liricas. Dos pouquíssimos papéis que guardo, procurando há pouco tempo algum poema da tão saudosa Luiza (que encontrei!) descobri que tenho uma mão cheia de coisas de 57-60 todas desse teor lírico. Por alguma, a tal, razão não as publiquei (algumas sairam em jornais em 58-59); tivesse-as eu publicado no caderno Poesia 6l, e hoje haveria mais coesão na minha obra.

- Como evoluiu desde então a tua poesia? Este Três Rostos tem ainda algum do olhar de então?

- O meu poema começou curto, leve, cadenciado, depois foi pausadamente aumentando em largueza de versos e comprimento de poemas, até fiz uns rectângulos gráficos estróficos pelo meio - ut pictura poesis. Em 86, no livro Âmago I - Nova Arte, o poema encurtou de novo e ell tornei-me outra vez mais mimosa para com ele com certos cuidados que a respiraço cura requer. Por diversas maneiras, tenho piraçao curta requer. Por diversas manciras, tenh estaco sempre a dizer o mesmo: da pequena vida do contimento cicunsancial ao Conhecinento. Tive um livio lirico frontal, logo en 60, chamado (Este) Rosto. Agora que tenho meio século de idade, já m lembro tanto e muito do passado mais distante. Assin estou a escrever muito sobre eu-passadamente. Talvez tenha três rostos - um virado para trás, outro no meio, para o presente, outro ainda vivo, para o futuro. No papel, são três livros.

Figura 10 - A Phala, no 15, 1989 


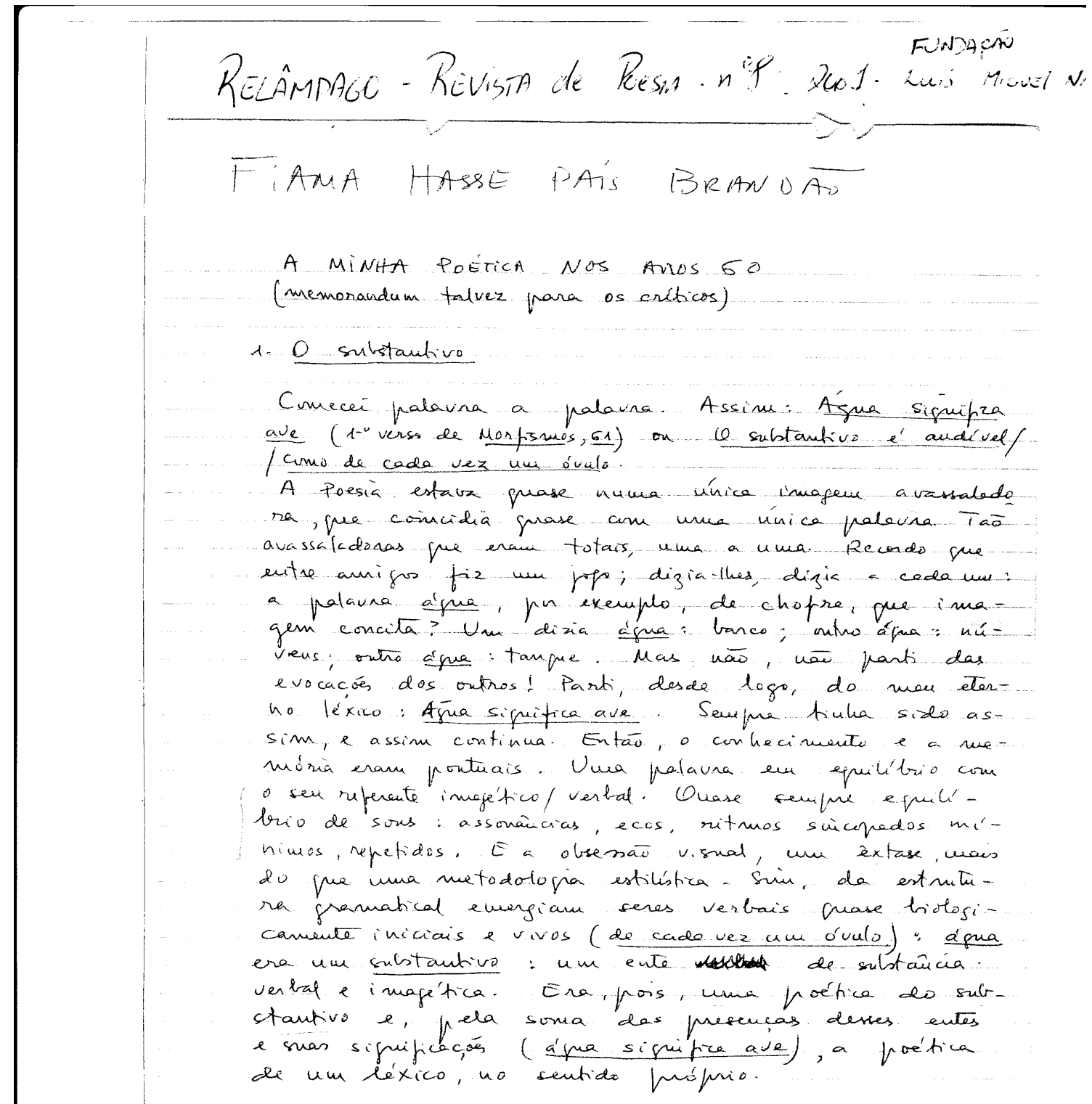

Figura 11 - Relâmpago - Revista de Poesia, no 8, 2001

170 


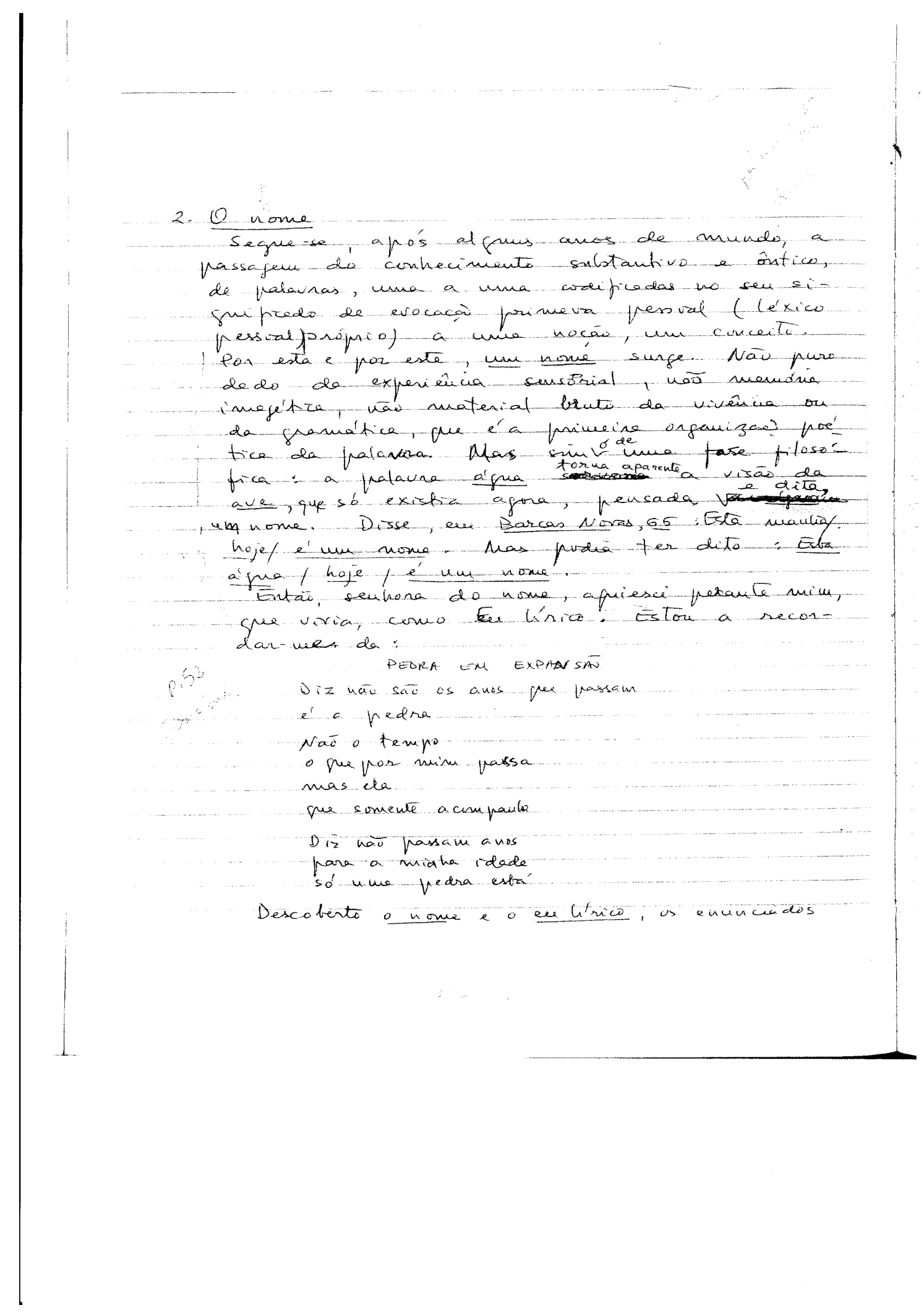

Figura 12 - Relâmpago - Revista de Poesia, no 8, 2001 


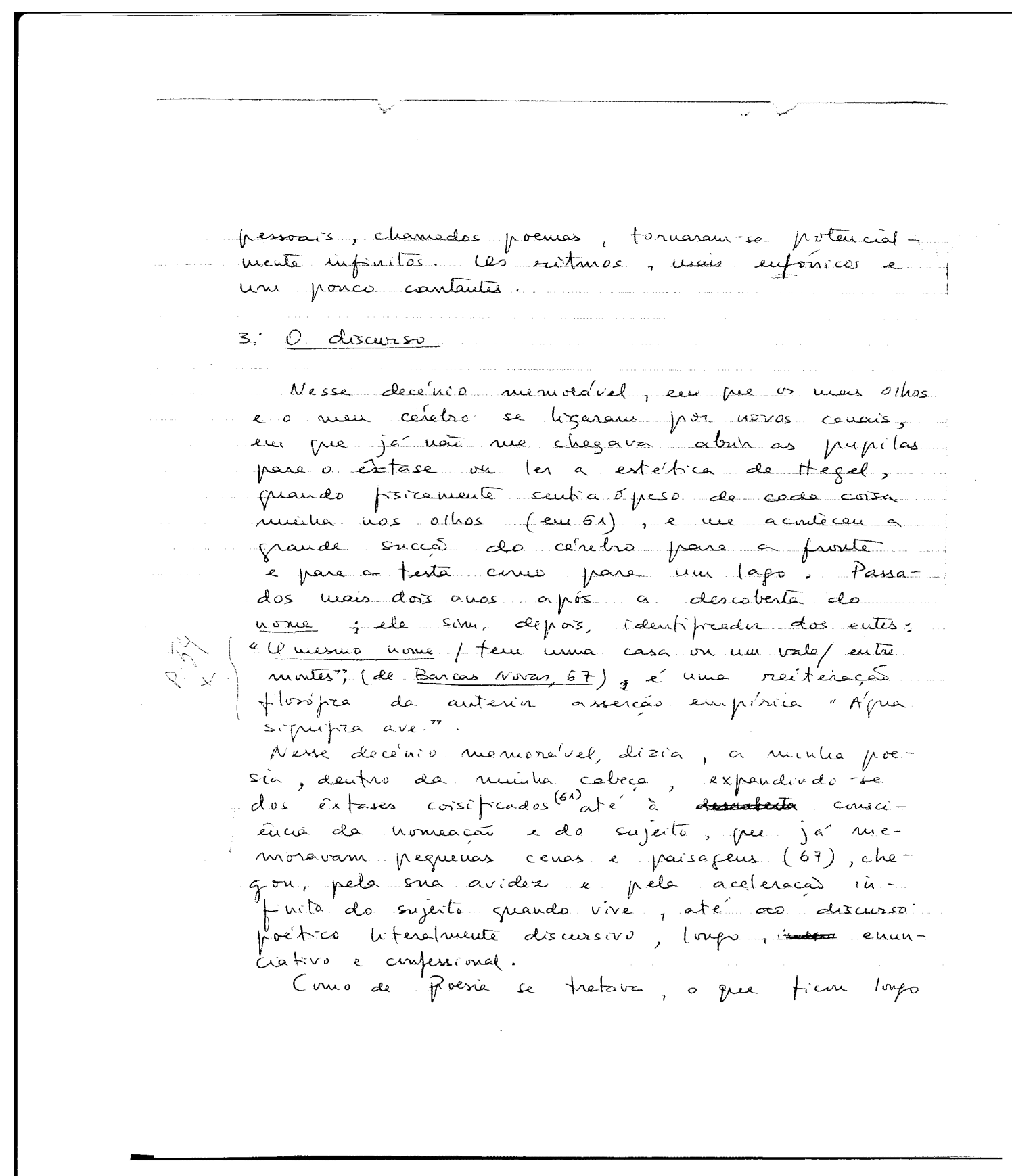

Figura 13 - Relâmpago - Revista de Poesia, no 8, 2001 


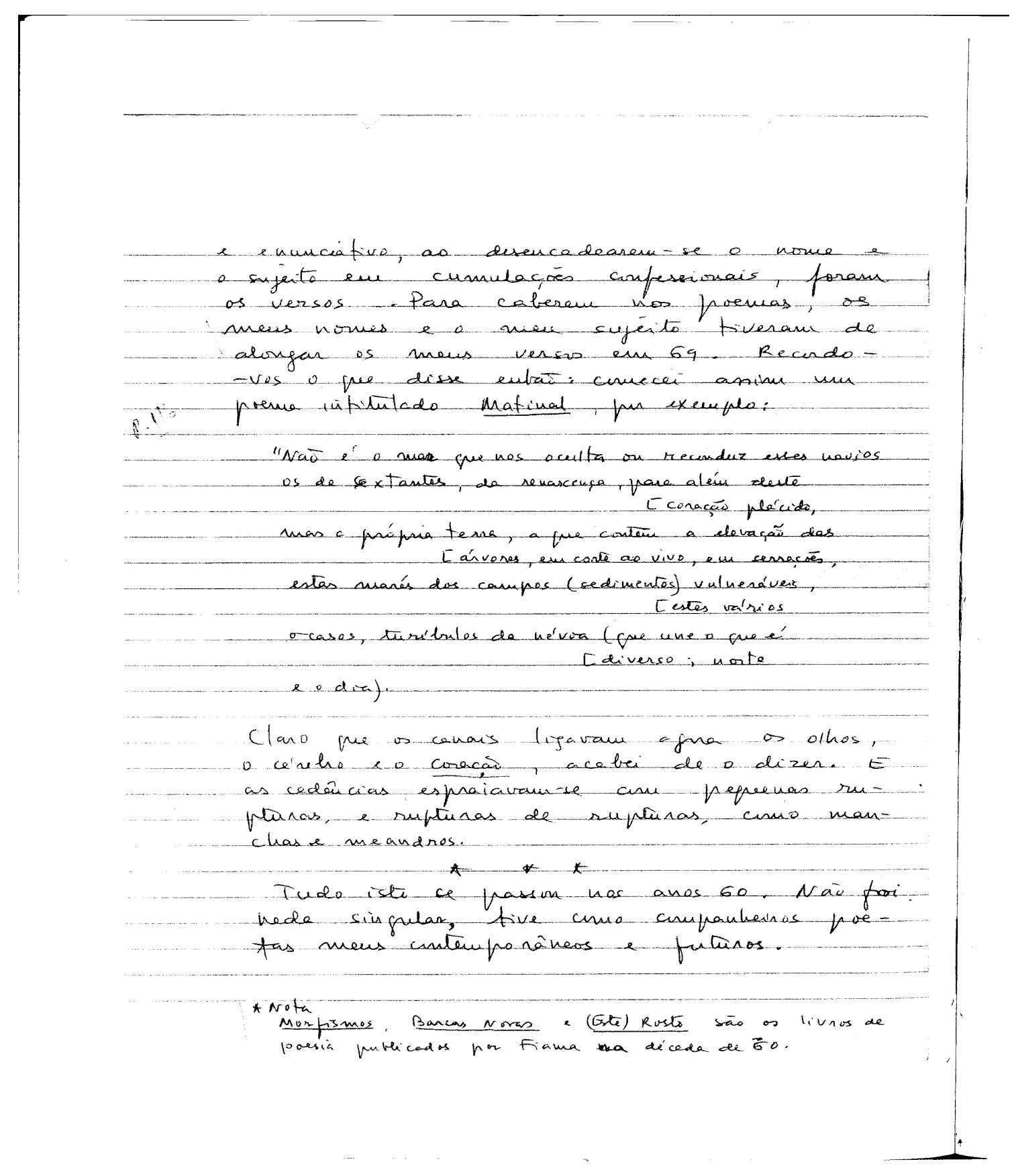

Figura 14 - Relâmpago - Revista de Poesia, no 8, 2001 


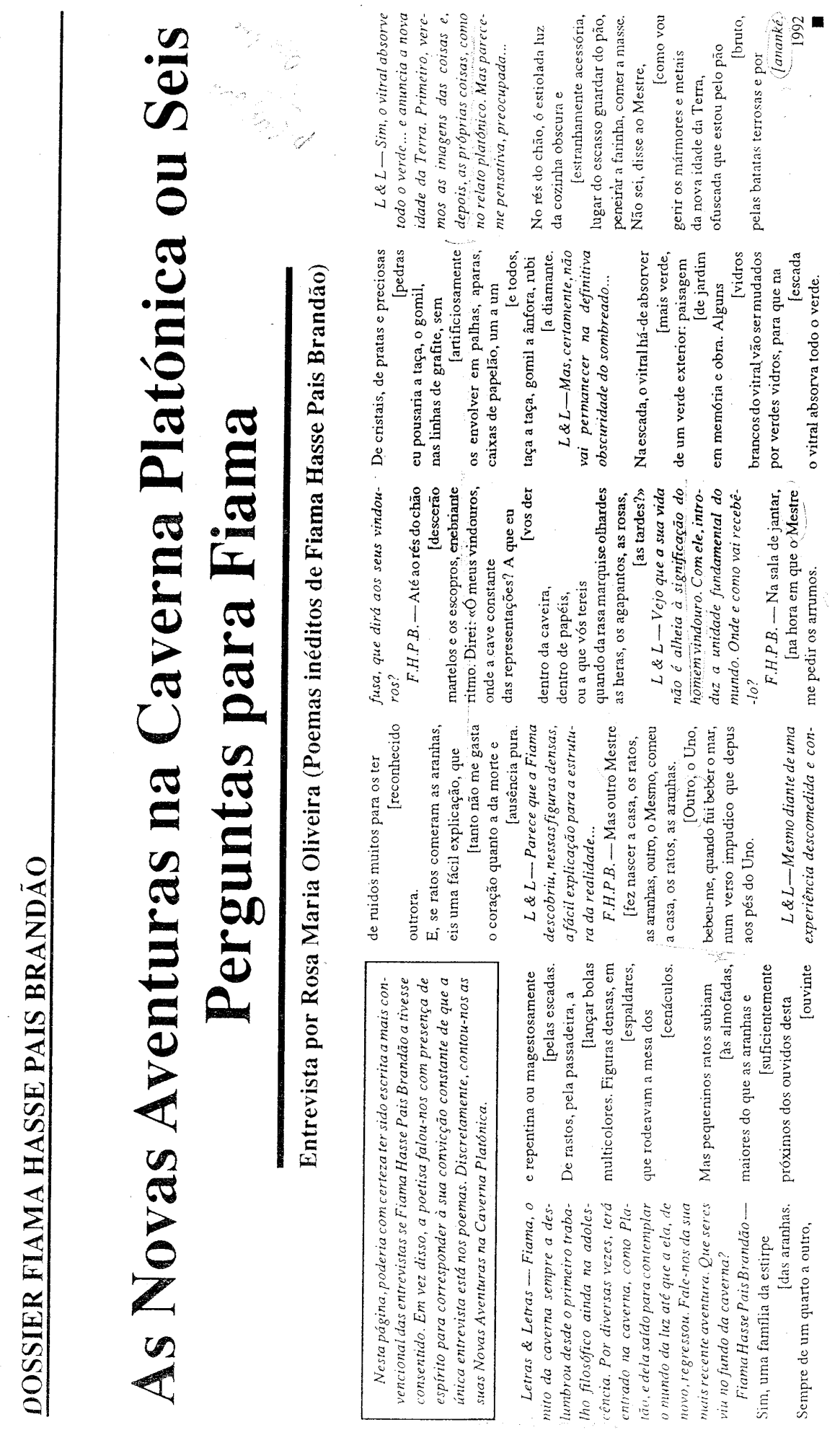

Figura 15 - “Dossier Fiama Hasse Pais Brandão” - Letras\&Letras, n81, 1992 


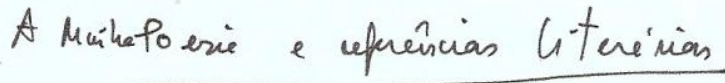

A minke posic teru reforencias continuedas explicitas e inplicitas a nutrus poetas propu tir a partic da ceitüre de seus premas gre en cunker a Poesiz. Antes de a ver uar crizas on no men íntivero, ouri-a em poernas.

Q primeino preme ve cunbeci, onvie decosei

(no auteintizo sentids literal) $p_{i}:$ Le $C_{a c}$ dit. Lamatrine. A minke humito aloz avó, crue sue loze branca, rentava-mo intequlmente, ve muika infanive. Eutas, o poevua le lac era afenas une ruisica, ume canto. Náo o indría no men real imediato. Nem a minke tenra issfaücie, nem o terue do poesure (le lac: o rio do tempo, "O'. trupps susperds ton vol) we permitiam passar desse preme à percepea / visaó do real. Das teve influence culturel, solve nuin, mais fue en teorie de música. Assim, a mustice lidede do decessilato prancer somede à musicali$d a d e$ das contiluas populares portucuesas - que une caseina do centro do pás cautava, ene iufuidas vellodias, av lony defotia - assims, passci anos de simples smoridedes pothicas, ate' que alcaucei o destumbramento da leiture de un lisro de

Figura 16 - Manuscrito de Fiama Hasse Pais Brandão, 1991 
poesia netional, Conal de soplià de Mello Brequer.

A partin de entä, desce Cond de Sophie de Mello Rrequer, crmecei a proter contrecer a vees real e as coisas de una forma prétice. E desenvolvi a pró. priá teorie de poesia, a poucs e pouco: fui perce ferinando, $m$ autes, veuds as nuetźfonas e as imegens dos pretas clánicus pontupuses (Nobe, Cesánis, Miraude, ck.) e fri, pare sempre, appendo a sua lúfue, sen léxico. Desia litura intusa dos au to res puntufuses recebio pee corsidero hoje o funda meuts da presia - a límpa nacional. Sin, a línsua! Isto $e^{\prime}$, as palavras, ar crijas, eo conaca que ar vê. Ume ensaista porturgês, Fruando Gui

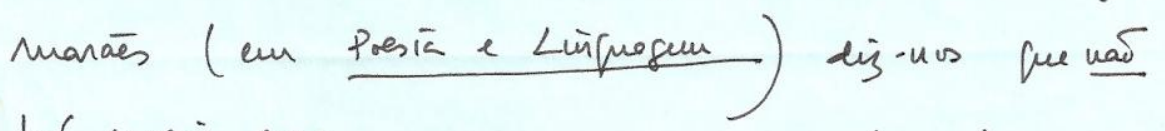
hé poesia uga; nav hé I'́rgna cega: a lingue fala e vè as coisas. E dessa lúgue, cormunu e simultäneamente litere'rie, I mique nat uga, Imige que vê (contimamente engendrands nutz'foras \& ine seus) parti pare a bigue des presuas, a I'úgua literária.

Assim, depiss de misha aprendizagen notural

Figura 17 - Manuscrito de Fiama Hasse Pais Brandão, 1991 
entre c famitie, a criadagem e os protas puturueses, chequei, pele force da compulsāo escotar, ż presic ennpreia. Felizmente, subliuho, nà só a poesia emopeia curtur forênea. fortíssime base porturpege, fui entā dielogar

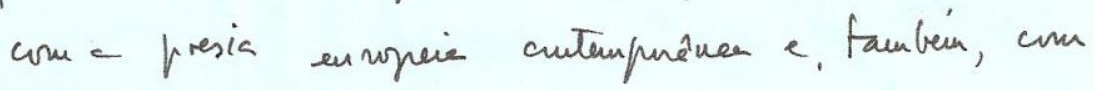
a fresie autge preco-lativa e judeotristä, a Prithe. Teuto de acentuan beur exta vasagem de autor eru autor, mais conso unu afrender da vide do gre como una aprendigageur livresca. Eu, quando li e quasto leis un preta, von aborveudo serupue c sue teonè do real, a sue expressividede en ceus sentimentos.

Ass poetas juntaram-se, evidentervente, os filo' sofo, was e'des poetas gue un talo hoje. Ao escrever poesia, en, necessaviemente, teria de expremir, entre as vivênias de nuika vida, essa experiêurio da leitura-convivio. Posso distinguir duas e'pocas enseuciais nessa

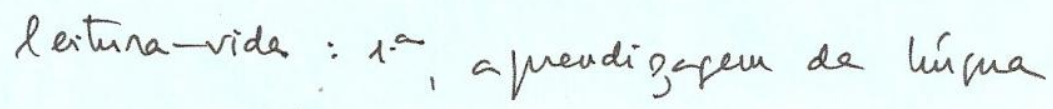
com is pretas portugueses; 2-; quendizasem do pensamento - e das ideologian - viétio -

Figura 18 - Manuscrito de Fiama Hasse Pais Brandão, 1991 
3

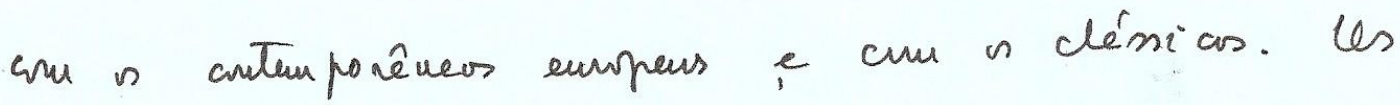
curtunporâneos, ne etcira de Mollarmé - o preta dn caligramas de pregmentacas verbal ensinaram-me s gue en desiguo pn ideolo. gias poeticas, que animilu temponeniamente \& depois abaudruei. Na époce das ideolosias - la terre est blare comme une orange de Ébard, e une dentelle s'abolit daus le donte de deallar мeí, enuncian une proframa de neetéfras frequentámas, hav comexas, u um contexto de fraquentacas cognitiz cinteuprosence - ve époce das ideologias, digo, a minke presic sopren un tempo de ranepaces verbal, une perda da língra. Porein, repidenueute, a foncéa do classismo das paudes epopeias, do paude Linisuo bucólico, aliade a frice de gexedar tredical auglo. gerwânica ( sen es quecer os craudes pretas americours) e ao vigor da tredicán portuguess venceraur, une veg maise de uvo, a ideologia passagire do poema cons true'do en sis mate'ria verbal.

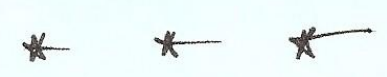

Figura 19 - Manuscrito de Fiama Hasse Pais Brandão, 1991

178 
$\varphi$

Dene diál. fo, on taluy unouloge, isto e', ei tudo - ver foi escrito e lido par minu, são testemuaks permenate e inevitásl, os puens pre mas. Un en citacós nomeadas, matacoés anónimas; $m$, entāo, tomando poemas nat conos teresas, was cone ofjecto poético, corvo un fruto, une pession, objectes pare sesem dercutes. Por vezes, entrequi nesceo explicitamente os mans texts a outio autor pe amei, ju exerupes, - poeta nudieral Joan Zono. Um dn mens livars intitulase 6 texts de Joan Zono. Abun dam. fois, us mens poemas, os t'tulos 2 as referéurias classizantes, bitticas, auglofermênicas, prancesar, e, solutudo, porturger sas, homenegerer à minke purfunda ma triz nacuovial. Anime, un tínto de unu dor mans livars é Honeneguna litereture.

Recenteruente, exthe antores referides on tranciuts promim, estou a aitas-ue a minu messua! - como se en forse un Pre ta, unu Poeta-westre, ame a idode de trinte aur de eraita, monta/vira.

E, citando-ue: "Escreveurs sole o anterin...

Figura 20 - Manuscrito de Fiama Hasse Pais Brandão, 1991

179 
5

"Lápide e versaos, indistintamente", it. $e^{\prime}$, "Nous e'aivous sur 1'ántériein ".... Piene de trube et version, " la firs"

J'écis sur l'autinieuse, Guer dizer, sole os premas - depion dor premas, $p^{\prime}$ escritu. 6 anterion on e' nene lajpide (tudo está or', fixo) on, eutāo, une susas, mue istergretad, ens mim, para sem. Wre. Assim, cunfesso: en escress como os poetas, e cum os Pretas.

$10 / 11 / 91$

Figura 21 - Manuscrito de Fiama Hasse Pais Brandão, 1991

180 
Bibliografia 


\section{De Fiama Hasse Pais Brandão}

\section{Artigos e Ensaio}

BRANDÃO, Fiama Hasse Pais. et alii. "Poesia - 61" in Diário de Lisboa, Lisboa: 25 de Maio, 1961.

. "Prefácio à Homenagemàliteratura"in Homenagemàliteratura. Porto:

Editora Limiar, 1976.

. Sílvia de Lisardo - Os sonetos. Organização e prefácio. Lisboa: Assírio \& Alvim, 1987.

. "O Triplo nome Sophia" in A Phala - um século de poesia. Lisboa:

Assírio \& Alvim, 1988.

. "Três Rostos - Fiama Hasse Pais Brandão" in A Phala $n^{\circ} 15$, jul./ago./set./1989. Lisboa: Assírio \& Alvim, 1989, p.1.

"A minha Poesia e referências literárias". Texto manuscrito escrito em 10 de Nov. de 1991 e apresentado por ocasião do Colóquio Fiama Hasse Pais Brandão 29 e 30 de out.2010.

- "As novas aventuras na caverna platônica ou seis perguntas para Fiama" entrevista por Rosa Maria Oliveira in Dossier Fiama Hasse Pais Brandão in Letras e Letras, Porto: AnoV, n 81, 21 de outubro de 1992.

“ "A minha poética nos anos 60" in Relâmpago $n^{\circ} 8$, Revista de Poesia. Lisboa: Relógio d'Água, 2001.

.O Labirinto Camoniano e outros labirintos. Lisboa: Teorema, 2007, $2^{\mathrm{a}}$ edição.

\section{Poesia e Prosa}

Espólio (poemas escritos em 1956 e 1957). Separata da Revista Ocidente, 1989.

F de Fiama (nove biografias) Antologia própria. Lisboa: Teorema, 1986. 
. Sob o Olhar de Medeia. Lisboa: Relógio d'Água, 1998.

. Obra Breve - Poesia Reunida. Lisboa: Assírio \& Alvim, 2006.

. Em cada pedra um voo imóvel e outros textos. Lisboa: Assírio \& Alvim, 2008.

Âmago - Antologia. Lisboa: Assírio \&Alvim, 2010.

\section{Sobre Fiama Hasse Pais Brandão}

AMARAL, Fernando Pinto do. "O Regresso ao Sentido - anos 70-80" in A Phala: um século de poesia (1888-1988). Lisboa: Assírio \& Alvim, pp. 158-167.

COELHO, Eduardo Prado. A noite do mundo. Lisboa: Imprensa Nacional - Casa da Moeda, 1988.

. "Apresentação de um livro: '(Este) rosto"” in A palavra sobre a palavra.

Porto: Portucalense, 1972.

. "Fiama Hasse Pais Brandão: poesia e escassez" in $O$ reino flutuante.

Lisboa: Edições 70, 1972.

COLÓQUIO 177. "Poesia 61". Revista quadrimestral. Lisboa: Fundação Calouste Gulbenkian, maio/ agosto 2011.

CORTEZ, António Carlos. "Fiama - Novas visões depois de ler" in Revista pessoa n $^{\circ} 2$ - Lembrar Fiama, revista de ideias. Lisboa: Casa Fernando Pessoa, março de 2011.

CRUZ, Gastão. A Vida da Poesia. Textos críticos reunidos. Lisboa: Assírio \&Alvim, 2008.

. A Poesia Portuguesa Hoje. Lisboa: Relógio d'Água, 1999.

. "Quando eu vir vaguear por dentro da casa" - Fiama Hasse Pais

Brandão in Século de Ouro (antologia crítica da poesia portuguesa do século XX). Org. e Intr. De Osvaldo Manuel Silvestre e Manuel Serra. Lisboa: Cotovia, 2002. 
. "Sobre Fiama - uma síntese" in Revista pessoa n ${ }^{\circ} 2$ - Lembrar Fiama, revista de ideias. Lisboa: Casa Fernando Pessoa, março de 2011.

"Dossier Fiama Hasse Pais Brandão". Letras \& Letras. Porto: AnoV, n 81, 21 de outubro de 1992.

EIRAS, Pedro. "Poéticas das Sequóias Gigantes - sobre a poesia de Fiama Hasse Pais Brandão" in Relâmpago n8, Revista de Poesia. Lisboa: Relógio d’Água, 2001.

. "Quatro palavras para recomeçar a ler Fiama" in Relâmpago $n^{\circ} 19$,

Revista de Poesia. Lisboa: Relógio d'Água, 2006. . "Fiama, a escolha da terra" in Revista pessoa no 2 - Lembrar Fiama, revista de ideias. Lisboa: Casa Fernando Pessoa, março de 2011.

FERRAZ, Maria de Lourdes A. "Uma proposta imodesta - a poética de Fiama: breves apontamentos. Revista pessoa $\mathrm{n}^{\mathrm{o}} 2$ - Lembrar Fiama, revista de ideias. Lisboa: Casa Fernando Pessoa, março de 2011.

FIALHO, Maria do Céu. “As vozes Greco-romanas na sinfonia poética de Fiama” in Revista pessoa $\mathrm{n}^{\circ} 2$ - Lembrar Fiama, revista de ideias. Lisboa: Casa Fernando Pessoa, março de 2011.

FRIAS, Joana Matos. "Às vezes as coisas dentro de nós - figuras inconsúteis no teatro da memória de Fiama" in Revista pessoa n n $^{\circ}$ - Lembrar Fiama, revista de ideias. Lisboa: Casa Fernando Pessoa, março de 2011.

GUIMARÃES, Fernando. A Poesia Contemporânea Portuguesa e o fim da modernidade. Lisboa: Ed. Caminho, 1989.

A Poesia contemporânea portuguesa. Apartado: Ed. Quase, 2002. (2a . Ed.).

. "Fiama Hasse Pais Brandão: silêncio e vida interior" in Relâmpago $n^{\circ} 8$, Revista de Poesia. Lisboa: Relógio d'Água, 2001.

GUSMÃO, Manuel. "A nomeação lírica e o amor pelos livros" in Revista pessoa $\mathrm{n}^{\circ} 2$ Lembrar Fiama, revista de ideias. Lisboa: Casa Fernando Pessoa, março de 2011. 
JÚDICE, Nuno. "O contar em Fiama" in Revista pessoa n ${ }^{\circ} 2$ - Lembrar Fiama, revista de ideias. Lisboa: Casa Fernando Pessoa, março de 2011.

LOURENÇO, Eduardo. "Entre o ser e o silêncio - cem anos de poesia portuguesa" in $A$ Phala: um século de poesia (1888-1988). Lisboa: Assírio \& Alvim, pp. 202 - 207.

- "Fiama ou o inelutável” prefácio de Obra Breve de Fiama Hasse Pais Brandão. Lisboa: Assírio \& Alvim, 2006.

. "Senhora do silêncio ou a poesia imemorial" in Revista pessoa $\mathrm{n}^{\mathrm{o}} 2$ -

Lembrar Fiama, revista de ideias. Lisboa: Casa Fernando Pessoa, março de 2011.

MARTELO, Rosa Maria. "Fiama e a 'fala perfeita"" in Em parte incerta. Estudos de poesia portuguesa moderna e contemporânea. Porto: Campo das Letras, 2004.

- "Ideações da imagem na poesia de Fiama Hasse Pais Brandão" in Revista pessoa $\mathrm{n}^{\mathrm{o}} 2$ - Lembrar Fiama, revista de ideias. Lisboa: Casa Fernando Pessoa, março de 2011.

MARTINHO, Fernando J.B. “A Erma Visão" in Relâmpago $n^{\circ} 8$, Revista de Poesia. Lisboa: Relógio d'Água, 2001.

. "Fiama: "um canto de epifania"" in Revista pessoa $\mathrm{n}^{\circ} 2$ - Lembrar

Fiama, revista de ideias. Lisboa: Casa Fernando Pessoa, março de 2011.

NAVA, Luís Miguel. "Os anos 60 - Realismo e Vanguarda in A Phala: um século de poesia (1888-1988). Lisboa: Assírio \& Alvim, pp. 150 - 157.

. "Os Poemas em Branco de Fiama Hasse Pais Brandão" in Ensaios

Reunidos. Lisboa: Assírio \& Alvim, 2004, p.218 - 225.

REIS, Carlos. "A Poesia Portuguesa na Posteridade do Modernismo" in Metamorfoses 6, Revista de Literatura. Rio de Janeiro/ Lisboa: UFRJ e Caminho, 2005.

ROSA, António Ramos. A Poesia moderna e a interrogação do real - I. Lisboa: Arcádia, 1979.

. “ (Este) Rosto de Fiama Hasse Pais Brandão in A Poesia Moderna e a interrogação do Real - II. Lisboa: Arcádia, 1980. 
. "Fiama Hasse Pais Brandão ou o espaço da infinidade" in Incisões oblíquas - estudos sobre poesia portuguesa contemporânea. Lisboa: Caminho, 1987.

SILVA, João Amadeu Oliveira Carvalho da. "A poesia de Fiama Hasse Pais Brandão um modo de tratar a realidade por tu" in Revista Portuguesa de Humanidades, vol. 8, Braga: Faculdade de Filosofia de Braga, 2004.

SILVESTRE, Osvaldo Manuel \& SERRA, Pedro. "Desaprender (com) a história” in Século de Ouro (antologia crítica da poesia portuguesa do século XX). Org. e Intr. De Osvaldo Manuel Silvestre e Manuel Serra. Lisboa: Cotovia, 2002.

SILVEIRA, Jorge Fernandes da. Portugal Maio de Poesia 61. Lisboa: Imprensa Nacional - Casa da Moeda, 1986.

. "Os trabalhos e os dias de Fiama Hasse Pais Brandão" in Metamorfoses $n^{\circ} 6$, Revista de Literatura. Rio de Janeiro/ Lisboa: UFRJ e Caminho, 2005.

Lápide e Versão - Ensaios sobre Fiama Hasse Pais Brandão. Rio de Janeiro: Bruxedo, 2006.

. "Grafia Epigrafia Grafiamas" in Revista pessoa n ${ }^{\circ} 2$ - Lembrar Fiama, revista de ideias. Lisboa: Casa Fernando Pessoa, março de 2011.

SOUSA, Carlos Mendes de. "Na sabedoria de uma quietude: Três Rostos de Fiama" in Relâmpago $n^{\circ} 8$, Revista de Poesia. Lisboa: Relógio d'Água, 2001.

. "Âmago: o mar" in Revista pessoa n ${ }^{\circ} 2$ - Lembrar Fiama, revista de ideias. Lisboa: Casa Fernando Pessoa, março de 2011.

Bibliografia geral

AGAMBEN, Giorgio. A Linguagem e a morte. Belo Horizonte: Editora UFMG, 2006. . O que é o contemporâneo? E outros ensaios. Chapecó: Argos, 2009.

ANDRESEN, Sophia de Mello Breyner. Obra Poética - vol. 1. Lisboa: Editorial Caminho, 1995. 
ARGAN, Giulio Carlo. Arte Moderna. São Paulo: Companhia das Letras, 1996.

BARRENTO, João. "Paul Celan: o Verbo e a Morte" in Sete Rosas mais tarde. Lisboa: Cotovia, 1996. (p. XXIX - XXXV).

. "Ensaio sobre a terceira voz - Quem fala no texto traduzido" in:

Colóquio Letras no.155/ 156, jan. 2000. Lisboa: Calouste Gulbenkian, 2000. ( p.275289).

BARTHES, Roland. S/Z. Paris: Éditions du Seuil, 1970.

Inéditos. Vol. 1 - teoria. São Paulo: Martins Fontes, 2004.

Preparação do romance I. São Paulo: Martins Fontes, 2005a.

. Preparação do romance II. São Paulo: Martins Fontes, 2005b.

BERARDINELLI, Alfonso. Da Poesia à Prosa. São Paulo: CosacNaif, 2007.

BLANCHOT, Maurice. O Livro por vir. São Paulo: Martins Fontes, 2005.

BORGES, Jorge Luis. Obras Completas II. São Paulo: Ed. Globo, 2000.

BUBER, Martin. Eu e Tu. (intr. e trad. de Newton Aquiles Von Zuben). São Paulo: Centauro Ed., 2009.

BLOOM, Harold. A Angústia da Influência. Rio de Janeiro: Imago, 1991.

CALVINO, Italo. Seis Propostas para o Próximo Milênio. São Paulo: Companhia das Letras, 1993.

CAMÕES, Luís de. Os Lusíadas. Porto: Porto Ed., 1983.

CAMPOS, Augusto de. VIA Linguaviagem. São Paulo: Cia das Letras, 1987.

. Poesia da Recusa. São Paulo: Perspectiva, 2006.

. Byron e Keats. Entreversos. Campinas: Unicamp, 2009.

CAMPOS, Haroldo. Galáxias. (1ª . ed. 1984). São Paulo: Editora 34, 2004. (2a . ed.) 
CELAN, Paul. Arte Poética - O Meridiano e outros textos (org.,posfácio e notas de João Barrento). Lisboa: Cotovia, 1996 a. Sete Rosas mais tarde. Lisboa: Cotovia, 1996 b.

CHEVALIER, Jean \& GHEERBRANT, Alain. Dicionário de Símbolos. Rio de Janeiro: José Olympio, 2002.

COSTA, Horácio. Mar Aberto- vol.1. São Paulo: Lumme Editor, 2010.

FRIEDRICH, Hugo. Estrutura da Lírica Moderna. São Paulo: Duas Cidades, 1978.

GADAMER, Hans-Georg. Quem sou eu, quem és tu? Rio de Janeiro: Ed. UERJ, 2005.

GARCEZ, Maria Helena Nery. O Tabuleiro Antigo. São Paulo: Edusp, 1990.

GILES, Thomas Ransom. História do Existencialismo e da Fenomenologia. São Paulo: E.P.U., 2003.

GIL, José. Movimento Total - o corpo e a dança. São Paulo: Iluminuras, 2005.

HAMBURGER, Michael. A verdade da Poesia. São Paulo: CosacNaif, 2007.

HEIDEGGER, Martin. Arte y Poesia (trad. y prólogo de Samuel Ramos). 1ª. Ed. 1958, D.F. México: EFE, 2001.

Lógica. A pergunta pela essência da linguagem. Lisboa: Calouste Gulbenkian, 2008.

. Acheminement vers la parole. Paris: Gallimard, 1976.

HÖLDERLIN, Martin. Poemas (tradução e introdução de José Paulo Pais). São Paulo: Cia das Letras, 1991.

Poemas (prefácio, seleção e tradução de Paulo Quintela). Lisboa: Relógio d'Água, 1991. Elegias (tradução e prefácio de Maria Teresa Dias Furtado). Lisboa: Assírio \& Alvim, 1999. 
Hinos Tardios (tradução e prefácio de Maria Teresa Dias Furtado).

Lisboa: Assírio \& Alvim, 2000.

A morte de Empédocles. (tradução e introdução de Marise Moassab

Curioni). São Paulo: Iluminuras, 2008.

JAKOBSON, Roman. Linguistica e Comunicação. São Paulo: Cultrix, 1975.

KERMODE, Frank. Um apetite pela poesia. São Paulo: EDUSP, 1993.

LANGLOIS, José Miguel Ibanez. La Creacion Poetica. Madrid: Ediciones Rialp, 1964.

LIMA, Luiz Costa. Teoria da literatura em suas fontes. (2 vols.). Rio de Janeiro: Paz e Terra,1983.

NOVAES, Adauto. "Pensar o mundo" in: Poetas que pensaram o mundo. (Org.). São Paulo: Cia das Letras, 2005.

NUNES, Benedito. Hermenêutica e Poesia. Belo Horizonte: UFMG, 2007.

OLIVEIRA, Carlos de. Finisterra. Lisboa: Assírio \& Alvim, 2003.

OVÍDIO. Metamorfoses. (trad. e notas de Bocage). São Paulo: Hedra, 2007.

PAES, José Paulo. "O Regresso dos deuses. Uma introdução à poesia de Hölderlin” in Poemas de Friedrich Hölderlin. (trad. e introd. de José Paulo Paes). São Paulo: Cia das Letras, 1991.

PAREYSON, Luigi. Os Problemas da estética. (trad. Maria Helena Garcez). São Paulo: Martins Fontes, 1997.

Esistenza e Persona. 4a ${ }^{\mathrm{a}}$ Ed. Genova: Il Melangolo, 1985.

- Verdade e Interpretação. (trad. Maria Helena Garcez e Sandra Neves Abdo). São Paulo: Martins Fontes, 2005.

PAZ, Octavio. O arco e a lira. (trad. Olga Savary). Rio de Janeiro: Nova Fronteira, 1982.

Obras completas 11- Obra Poética I. D.F.: México, Fondo de Cultura Económica, 1997. 
PESSOA, Fernando. Obra Poética. Rio de Janeiro: Ed. Nova Aguilar, 1990. Mensagem - Poemas esotéricos. Ed. Crítica José Augusto Seabra, coordenador. 2ª ${ }^{\text {a }}$ Ed. Madrid: Paris: México: Buenos Aires: São Paulo: Rio de Janeiro, Lima: ALLCA XX/ EDUSP, 1996. (Coleção Archivos).

RILKE, Rainer Maria. As Elegias de Duíno. ( introdução e tradução de Maria Teresa Dias Furtado) - 2a . Ed. Lisboa: Assírio \& Alvim, 2002. Os cadernos de Malte Laurids Brigge. (trad. Lya Luft). Rio de Janeiro: Nova Fronteira, 1979.

RODRIGUES, Silvina. A Legitimação em literatura. Lisboa, Edições Cosmos, 1994.

STEINBERG, Vivian. "No Poema”: um paradigma da tessitura poética de Sophia de Mello Breyner Andresen. Dissertação de mestrado apresentada na USP, São Paulo: 2006.

STEINER, George. Gramáticas da Criação. São Paulo: Globo, 2003.

WERLE, Marco Aurélio. Poesia e pensamento em Hölderlin e Heidegger. São Paulo: UNESP, 2004.

\section{Vivian Steinberg}

email: viviansteinberg@terra.com.br 